\title{
Palladium-Catalyzed Denitrative $\alpha$-Arylation of Ketones with Nitroarenes
}

Zhirong Li, Yonggang Peng, and Tao $\mathrm{Wu}^{*}$

The college of Chemistry, Nanchang University, Nanchang, Jiangxi 330031, P. R. China

Supporting Information

Table of Contents

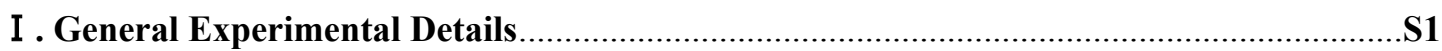

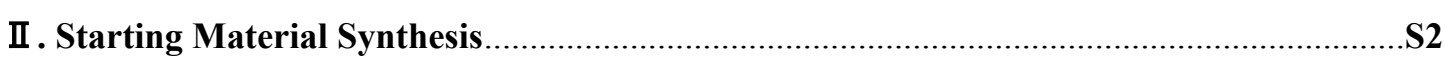

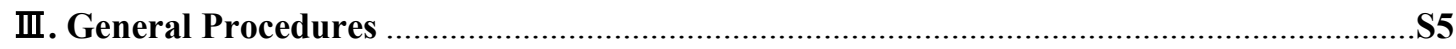

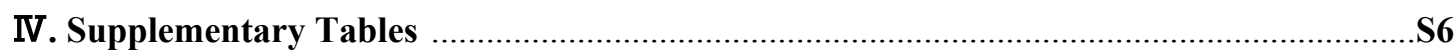

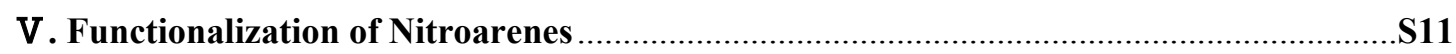

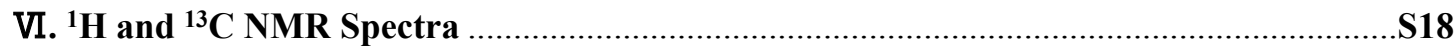

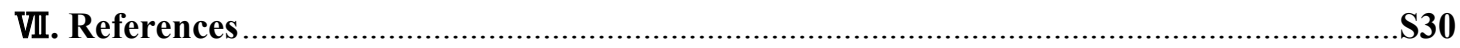




\section{I . General Experimental Details}

Unless otherwise noted, all reactants or reagents including dry solvents were obtained from commercial suppliers and used as received. Pd catalysts (as $\mathrm{Pd}(\mathrm{acac})_{2}$ ed.), corresponding ligands (as Brettphos ed.), and all kinds of bases were obtained from Tansoole and Innochem Chemical. All dry solvents were obtained from Energy Chemical. Unless otherwise noted, all reactions were performed with dry solvents under an atmosphere of nitrogen gas in dried glassware using standard vacuum-line techniques. All reactions were isolated from moisture and oxygen by a nitrogen atmosphere with a sealed $10-\mathrm{mL}$ schlenk tube and heated in a heating module (heater + magnetic stirrer). All work-up and purification procedures were carried out with reagent-grade solvents in air.

Analytical thin-layer chromatography (TLC) was performed using silica gel HSGF254 precoated plates $(0.25 \mathrm{~mm})$. The developed chromatogram was analyzed by UV lamp $(254 \mathrm{~nm})$. Flash column chromatography was performed with silica gel (200-300 mesh). Preparative thin-layer chromatography (PTLC) was performed using YanTai jiangyou chemical Plant HuangHai GF254 silica coated plates $(0.20 \pm 0.03 \mathrm{~mm})$ prepared in our laboratory. Gas chromatography (GC) analysis was conducted on Agilent Technologies 7080A gaschromatography instrument with a FID detector with n-tetradecane as an internal standard. GC/MS analysis was conducted on a Shimadzu GCMSQP2010 instrument equipped with a Restec-5HT column (30 m $\times 0.25 \mathrm{~mm}$, Hewlett-Packard). The high-resolution mass spectra were conducted on 6545 Q-TOF LCMS instrument. Nuclear magnetic resonance (NMR) spectra were recorded on Bruker Advance III (400 MHz) spectrometers with tetramethylsilane as an internal standard. Chemical shifts for ${ }^{1} \mathrm{H}$ NMR are expressed in parts per million (ppm) relative to tetramethylsilane $(\delta 0.00 \mathrm{ppm})$ or residual peak of $\mathrm{CDCl} 3(\delta 7.26 \mathrm{ppm})$. Chemical shifts for ${ }^{13} \mathrm{C}$ NMR are expressed in ppm relative to $\mathrm{CDCl}_{3}(\delta 77.00 \mathrm{ppm})$. Data are reported as follows: chemical shift, multiplicity $(\mathrm{s}=$ singlet, $\mathrm{d}=$ doublet, $\mathrm{dd}=$ doublet of doublets, $\mathrm{t}=$ triplet, $\mathrm{dt}=$ doublet of triplets, $\mathrm{td}=$ triplet of doublets, $\mathrm{q}=$ quartet, $\mathrm{m}=$ multiplet, $\mathrm{v}=$ virtual coupling, br = broad signal), coupling constant $(\mathrm{Hz})$, and integration. 


\section{II . Starting Material Synthesis}

\section{General reaction procedure for the synthesis of $1 \mathrm{r}$ and $1 \mathrm{~s}$}

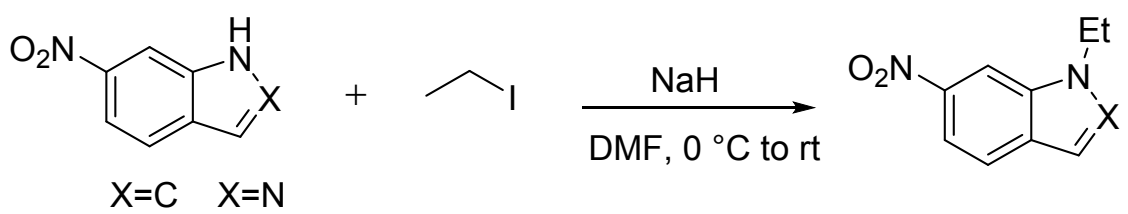

Based on a literature procedure ${ }^{1}$, to a stirred solution of indole $(10 \mathrm{mmol})$ in dry DMF $(20$ $\mathrm{mL}$ ), $\mathrm{NaH}$ (480 mg, 60\% suspension in mineral oil, $12 \mathrm{mmol}$ ) was added slowly at $0^{\circ} \mathrm{C}$. The reaction mixture was then warmed to room temperature and stirred for $30 \mathrm{~min}$. After cooling to $0^{\circ} \mathrm{C}$, iodoethane $(0.960 \mathrm{~mL}, 12 \mathrm{mmol})$ was added dropwise. Then, the reaction mixture was warmed to room temperature and stirred overnight. Once reaction was determined to be completed via thin layer chromatographic analysis, the reaction was quenched with water and the aqueous layer was extracted with ether. The combined organic layers were washed with brine, dried over anhydrous $\mathrm{Na}_{2} \mathrm{SO}_{4}$, and concentrated under reduced pressure. The residue was purified by column chromatography on silica gel to give compound as yellow solid. Product is a known substrate and matched the literature data.

\section{General reaction procedure for the synthesis of $4 \mathrm{~b}, 4 \mathrm{~d}, 4 \mathrm{e}, 4 \mathrm{f}, 4 \mathrm{~h}$}<smiles>O=C(Cl)Cc1ccccc1</smiles>

Based on a literature procedure ${ }^{2}$, Phenylacetyl chloride ( $2.65 \mathrm{ml}, 20 \mathrm{mmol}$ ) was stirred with the appropriate substituted benzene (excess) in $20 \mathrm{ml} \mathrm{CH} \mathrm{Cl}_{2}$ at $0^{\circ} \mathrm{C}$. Aluminum(II) chloride (3.1 $\mathrm{g}, 22 \mathrm{mmol}$ ) was added, and the reaction mixture was stirred at room temperature overnight. The reaction mixture was poured onto ice and extracted with ethyl acetate $(3 \times 20 \mathrm{~mL})$. The combined organic layers were evaporated and recrystallied using petroleum ether to afforded the target compound. Product is a known substrate and matched the literature data.

\section{General reaction procedure for the synthesis of 7}

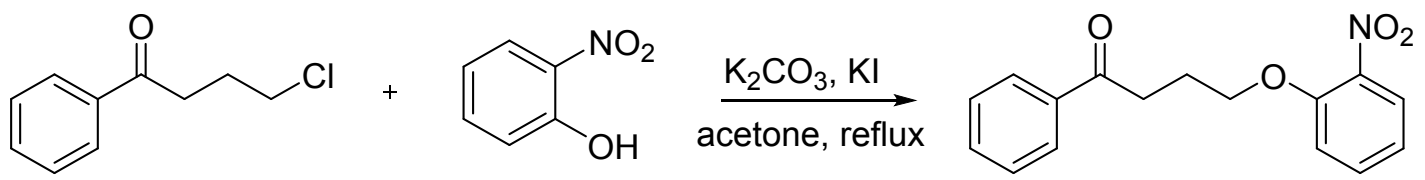

Based on a literature procedure ${ }^{3}$, 2-nitrophenol (1.0 eq.) and the respective alkyl halide (1.5 eq.) were dissolved in dry acetone $(20 \mathrm{ml})$. Potassiumcarbonate $(2.0$ eq.) and, if a chloride or bromide was used, potassiumiodide ( 0.5 eq.) were added. The reaction mixture was then heated to 
reflux until complete conversion of the starting material occurred (TLC). The solvent was subsequently removed under reduced pressure and the resulting residue was extracted with ethyl acetate $(3 \times 20 \mathrm{~mL})$. The combined organic layers were washed with brine, dried over anhydrous $\mathrm{Na}_{2} \mathrm{SO}_{4}$, and concentrated under reduced pressure. The residue was purified by column chromatography on silica gel to give compound. Product is a known substrate and matched the literature data.<smiles>CCn1ccc2ccc([N+](=O)[O-])cc21</smiles>

\section{1r}

${ }^{1} \mathrm{H}$ NMR $\left(400 \mathrm{MHz}, \mathrm{CDCl}_{3}\right) \delta 8.34(\mathrm{~s}, 1 \mathrm{H}), 8.01(\mathrm{dd}, \mathrm{J}=8.8,1.9 \mathrm{~Hz}, 1 \mathrm{H}), 7.65(\mathrm{~d}, \mathrm{~J}=8.8 \mathrm{~Hz}, 1 \mathrm{H})$, $7.42(\mathrm{~d}, \mathrm{~J}=3.1 \mathrm{~Hz}, 1 \mathrm{H}), 6.60$ (d, J = 3.1 Hz, 1H), 4.27 (q, J = 7.3 Hz, 2H), 1.53 (t, J = 7.3 Hz, 3H). The spectra are in accordance with those of the compound reported in the literature.<smiles>CCn1ncc2ccc([N+](=O)[O-])cc21</smiles>

\section{1s}

${ }^{1} \mathrm{H}$ NMR (400 MHz, CDCl $) \delta 8.40(\mathrm{~s}, 1 \mathrm{H}), 8.12(\mathrm{~s}, 1 \mathrm{H}), 8.01(\mathrm{~d}, \mathrm{~J}=8 \mathrm{~Hz}, 1 \mathrm{H}), 7.84(\mathrm{~d}, \mathrm{~J}=8 \mathrm{~Hz}$, $1 \mathrm{H}), 4.53(\mathrm{q}, \mathrm{J}=6 \mathrm{~Hz}, 2 \mathrm{H}), 1.57(\mathrm{t}, \mathrm{J}=6 \mathrm{~Hz}, 3 \mathrm{H})$.

The spectra are in accordance with those of the compound reported in the literature.<smiles>Cc1ccc(C(=O)Cc2ccccc2)cc1</smiles>

4b

${ }^{1} \mathrm{H}$ NMR (400 MHz, $\left.\mathrm{CDCl}_{3}\right) \delta 7.92(\mathrm{~d}, \mathrm{~J}=8.4 \mathrm{~Hz}, 2 \mathrm{H}), 7.33(\mathrm{~m}, 2 \mathrm{H}), 7.26(\mathrm{~m}, 5 \mathrm{H}), 4.26(\mathrm{~s}, 2 \mathrm{H})$, $2.41(\mathrm{~s}, 3 \mathrm{H})$.

The spectra are in accordance with those of the compound reported in the literature.<smiles>O=C(Cc1ccccc1)c1ccc(-c2ccccc2)cc1</smiles>

4d

${ }^{1} \mathrm{H} \mathrm{NMR}\left(400 \mathrm{MHz}, \mathrm{CDCl}_{3}\right) \delta 8.11(\mathrm{~d}, \mathrm{~J}=8.8 \mathrm{~Hz}, 2 \mathrm{H}), 7.69(\mathrm{~d}, \mathrm{~J}=8.4 \mathrm{~Hz}, 2 \mathrm{H}), 7.63(\mathrm{~m}, 2 \mathrm{H}), 7.48$ (m, 2H), $7.42(\mathrm{~m}, 1 \mathrm{H}), 7.32(\mathrm{~m}, 5 \mathrm{H}), 4.33(\mathrm{~s}, 2 \mathrm{H})$.

The spectra are in accordance with those of the compound reported in the literature. 
<smiles>COc1ccc(C(=O)Cc2ccccc2)cc1OC</smiles>

${ }^{1} \mathrm{H}$ NMR (400 MHz, CDCl3) $\delta 7.67(\mathrm{dd}, \mathrm{J}=8.4 \mathrm{~Hz}, 1 \mathrm{H}), 7.56(\mathrm{~d}, \mathrm{~J}=6 \mathrm{~Hz}, 1 \mathrm{H}), 7.25-7.33(\mathrm{~m}, 5 \mathrm{H})$, $6.88(\mathrm{~d}, \mathrm{~J}=8.4 \mathrm{~Hz}, 1 \mathrm{H}), 4.25$ (s, 2H), $3.94(\mathrm{~s}, 3 \mathrm{H}), 3.92$ (s, 3H).

The spectra are in accordance with those of the compound reported in the literature.<smiles>O=C(Cc1ccccc1)c1ccc2c(c1)OCCO2</smiles>

4f

${ }^{1} \mathrm{H} \mathrm{NMR}\left(400 \mathrm{MHz}, \mathrm{CDCl}_{3}\right) \delta 7.55(\mathrm{~m}, 2 \mathrm{H}), 7.31(\mathrm{t}, \mathrm{J}=8 \mathrm{~Hz}, 2 \mathrm{H}), 7.25(\mathrm{~m}, 3 \mathrm{H}), 6.89(\mathrm{~d}, \mathrm{~J}=8 \mathrm{~Hz}$, $1 \mathrm{H}), 4.27$ (m, 4H), 4.19 (s, 2H).

The spectra are in accordance with those of the compound reported in the literature.<smiles>O=C(Cc1ccc(F)cc1)c1ccccc1</smiles>

4h

${ }^{1} \mathrm{H} \mathrm{NMR}\left(400 \mathrm{MHz}, \mathrm{CDCl}_{3}\right) \delta 8.01(\mathrm{~d}, \mathrm{~J}=7.8 \mathrm{~Hz}, 2 \mathrm{H}), 7.58(\mathrm{t}, \mathrm{J}=7.3 \mathrm{~Hz}, 1 \mathrm{H}), 7.48(\mathrm{t}, \mathrm{J}=7.5 \mathrm{~Hz}$, $2 \mathrm{H}), 7.24-7.22(\mathrm{~m}, 2 \mathrm{H}), 7.03(\mathrm{t}, \mathrm{J}=8.3 \mathrm{~Hz}, 2 \mathrm{H}), 4.27(\mathrm{~s}, 2 \mathrm{H})$.

The spectra are in accordance with those of the compound reported in the literature.<smiles>O=C(CCCOc1ccccc1[N+](=O)[O-])c1ccccc1</smiles>

7

${ }^{1} \mathrm{H}$ NMR (400 MHz, $\left.\mathrm{CDCl}_{3}\right) \delta 8.01(\mathrm{dd}, \mathrm{J}=8 \mathrm{~Hz}, 2 \mathrm{H}), 7.83(\mathrm{dd}, \mathrm{J}=6 \mathrm{~Hz}, 1 \mathrm{H}), 7.51(\mathrm{~m}, 4 \mathrm{H}), 7.09$ $(\mathrm{d}, \mathrm{J}=8 \mathrm{~Hz}, 1 \mathrm{H}), 7.01$ (t, J = 8 Hz, 1H), $4.24(\mathrm{t}, \mathrm{J}=6 \mathrm{~Hz}, 2 \mathrm{H}), 3.29$ (t, J = $8 \mathrm{~Hz}, 2 \mathrm{H}), 2.29$ (m, 2H). The spectra are in accordance with those of the compound reported in the literature. 


\section{General Procedures}

\section{Procedure (A):}

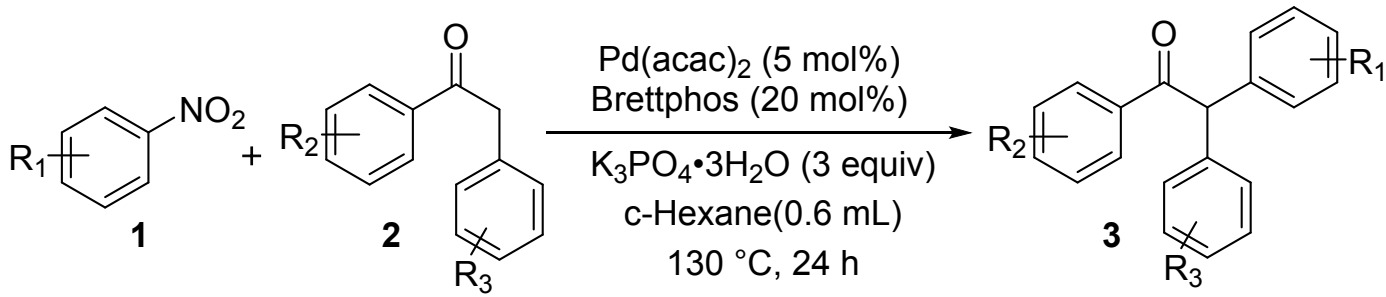

To an oven-dried tube equipped with a magnetic stirring bar were added sequentially nitroarene $1(0.1 \mathrm{mmol})$, ketones $2(0.12 \mathrm{mmol}), \mathrm{Pd}(\mathrm{acac})_{2}(1.5 \mathrm{mg}, 0.005 \mathrm{mmol})$, Brettphos $(10.7 \mathrm{mg}, 0.02$ $\mathrm{mmol}), \mathrm{K}_{3} \mathrm{PO}_{4} \cdot 3 \mathrm{H}_{2} \mathrm{O}(80 \mathrm{mg}, 0.3 \mathrm{mmol})$, and cyclohexane $(0.6 \mathrm{~mL})$ under $\mathrm{N}_{2}$ atmosphere. The reaction mixture was stirred and heated at $130{ }^{\circ} \mathrm{C}$ for 24 hours. The reaction mixture was cooled to room temperature, and then it was passed through a short pad of silica gel with EtOAc. The solution was concentrated in vacuo. The residue was purified by silica gel column chromatography to give the product 3 . The isolated yield on a $0.2 \mathrm{mmol}$ scale (two runs).

\section{Procedure (B):}

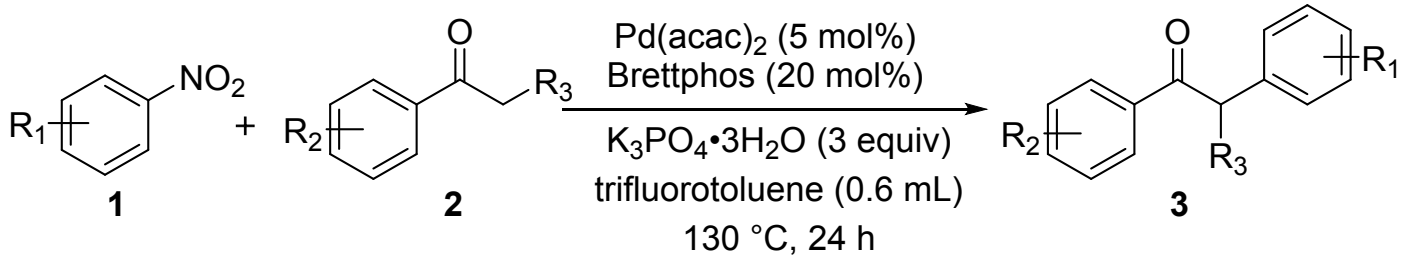

To an oven-dried tube equipped with a magnetic stirring bar were added sequentially nitroarene $1(0.3 \mathrm{mmol})$, ketones $2(0.1 \mathrm{mmol}), \mathrm{Pd}(\mathrm{acac})_{2}(1.5 \mathrm{mg}, 0.005 \mathrm{mmol})$, Brettphos $(10.7 \mathrm{mg}, 0.02$ $\mathrm{mmol}), \mathrm{K}_{3} \mathrm{PO}_{4} \cdot 3 \mathrm{H}_{2} \mathrm{O}(80 \mathrm{mg}, 0.3 \mathrm{mmol})$, and trifluorotoluene $(0.4 \mathrm{~mL})$ under $\mathrm{N}_{2}$ atmosphere. The reaction mixture was stirred and heated at $130{ }^{\circ} \mathrm{C}$ for 24 hours. The reaction mixture was cooled to room temperature, and then it was passed through a short pad of silica gel with ethyl acetate. The solution was concentrated in vacuo. The residue was purified by silica gel column chromatography to give the product 3 . The isolated yield on a $0.2 \mathrm{mmol}$ scale (two runs). 


\section{Supplementary Tables}

Table S1. Effect of the Solvent and Pd catalysts.

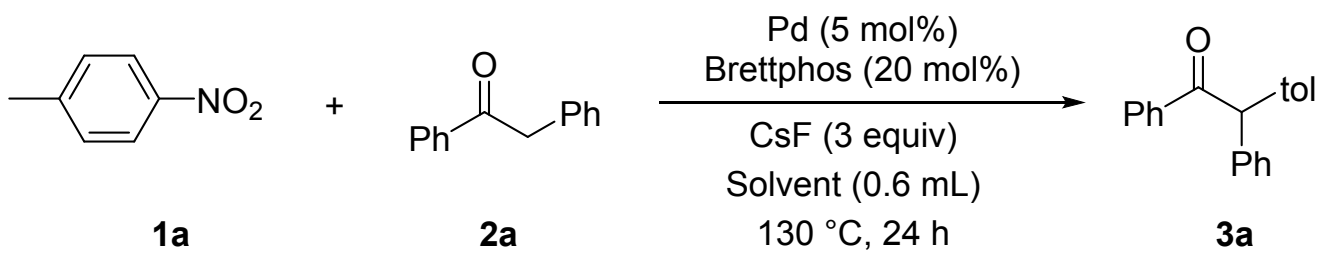

\begin{tabular}{|c|c|c|c|}
\hline Entry & Palladium catalyst & Solvent & Yield of $\mathbf{3 a}(\%)$ \\
\hline 1 & $\operatorname{Pd}(\mathrm{acac})_{2}$ & Dioxane & 45 \\
\hline 2 & $\operatorname{Pd}(\mathrm{acac})_{2}$ & THF & 35 \\
\hline 3 & $\operatorname{Pd}(\mathrm{acac})_{2}$ & c-hexane & 60 \\
\hline 4 & $\operatorname{Pd}(\mathrm{acac})_{2}$ & n-hexane & 60 \\
\hline 5 & $\operatorname{Pd}(\mathrm{acac})_{2}$ & n-heptane & 41 \\
\hline 6 & $\operatorname{Pd}(\mathrm{acac})_{2}$ & n-decane & 56 \\
\hline 7 & $\operatorname{Pd}(\mathrm{acac})_{2}$ & Toluene & 14 \\
\hline 8 & $\operatorname{Pd}(\mathrm{acac})_{2}$ & EtOAc & 30 \\
\hline 9 & $\operatorname{Pd}(\mathrm{acac})_{2}$ & $\mathrm{CCl}_{4}$ & 0 \\
\hline 10 & $\operatorname{Pd}(\mathrm{acac})_{2}$ & DMF & 16 \\
\hline 11 & $\operatorname{Pd}(\mathrm{acac})_{2}$ & DMA & 9 \\
\hline 12 & $\operatorname{Pd}(\mathrm{acac})_{2}$ & $\mathrm{CH}_{3} \mathrm{CN}$ & 4 \\
\hline 13 & $\operatorname{Pd}(\mathrm{acac})_{2}$ & DCE & 0 \\
\hline 14 & $\operatorname{Pd}(\mathrm{acac})_{2}$ & DMSO & 0 \\
\hline 15 & $\mathrm{PdCl}_{2}$ & c-Hex & 0 \\
\hline 16 & $\mathrm{Pd}\left(\mathrm{PPh}_{3}\right)_{4}$ & c-Hex & 0 \\
\hline 11 & $\mathrm{Pd}(\mathrm{OAc})_{2}$ & c-Hex & 55 \\
\hline 12 & $\mathrm{Pd}\left(\mathrm{CF}_{3} \mathrm{COO}\right)_{2}$ & c-Hex & 59 \\
\hline 13 & $\mathrm{Pd}_{2}(\mathrm{dba})_{3}$ & c-Hex & 0 \\
\hline 14 & $\operatorname{Pd}(\mathrm{dba})_{2}$ & c-Hex & 0 \\
\hline 15 & $\mathrm{PdCl}_{2}(\mathrm{PhCN})_{2}$ & c-Hex & 28 \\
\hline
\end{tabular}




$\begin{array}{llll}16 & \mathrm{PdCl}_{2}\left(\mathrm{CH}_{2} \mathrm{CN}\right)_{2} & \mathrm{c}-\mathrm{Hex} & 14 \\ 17 & \mathrm{PdCl}_{2}\left(\mathrm{PCy}_{3}\right)_{2} & \mathrm{c}-\mathrm{Hex} & 0 \\ 18 & \mathrm{PdCl}_{2}\left(\mathrm{PPh}_{3}\right)_{2} & \mathrm{c}-\mathrm{Hex} & 0\end{array}$

Table S2. Effect of the ligands.
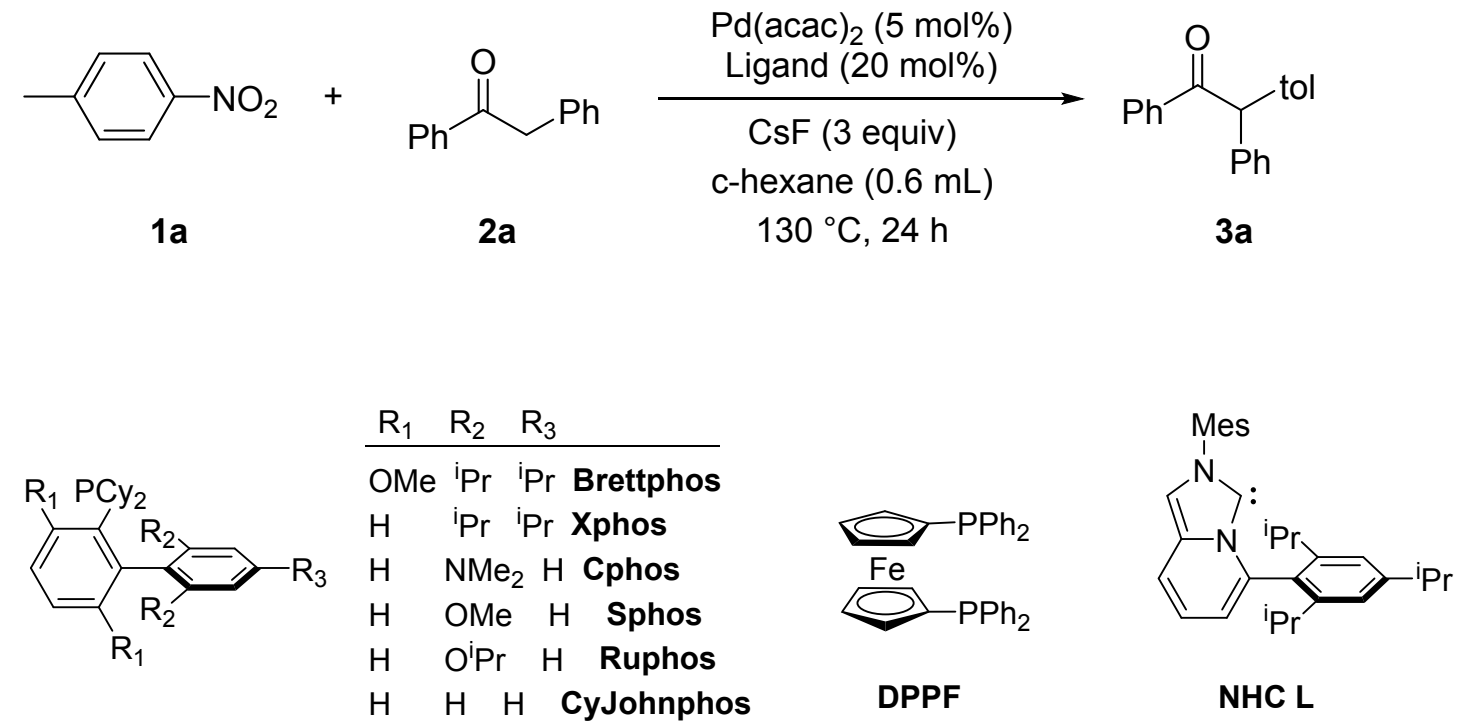

$\begin{array}{ccc}\text { Entry } & \text { Ligand } & \text { Yield of 3a (\%) } \\ 1 & \text { Brettphos } & 60 \\ 2 & \text { Xphos } & 0 \\ 3 & \text { Cphos } & 6 \\ 4 & \text { Ruphos } & 0 \\ 5 & \text { Sphos } & 0 \\ 6 & \text { CyJohnphos } & 0 \\ 7 & \text { DPPF } & 0 \\ 8 & \text { Rac-BINAP } & 0 \\ 9 & \text { NHC L } & 3\end{array}$

Table S3. Effect of the temperatures.

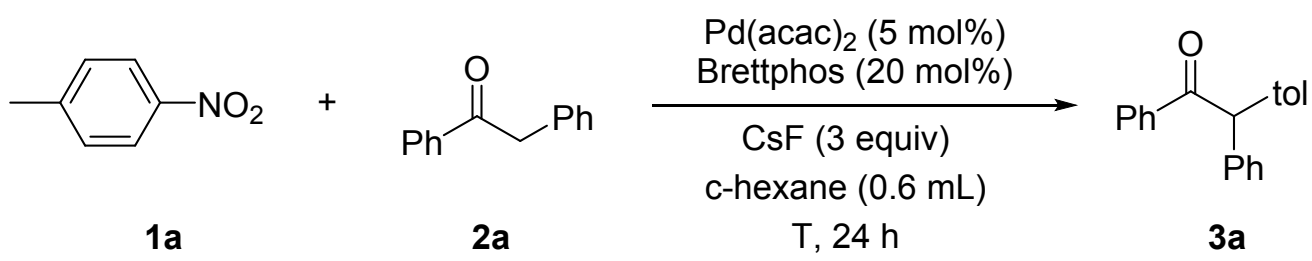




$\begin{array}{ccc}\text { Entry } & \text { Temperature }\left({ }^{\circ} \mathrm{C}\right) & \text { Yield of } \mathbf{3 a}(\%) \\ 1 & 110 & 16 \\ 2 & 130 & 60 \\ 3 & 150 & 67\end{array}$

Table S4. Effect of the bases

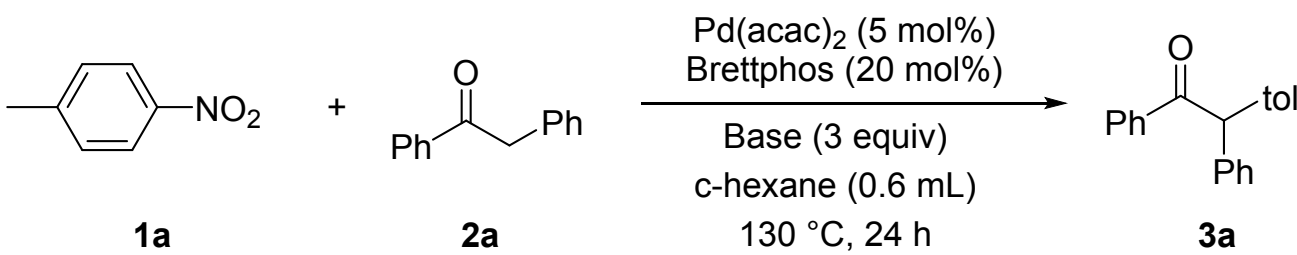

\begin{tabular}{|c|c|c|}
\hline Entry & base & Yield of 3a (\%) \\
\hline 1 & $\mathrm{CsF}$ & 60 \\
\hline 2 & $\mathrm{Cs}_{2} \mathrm{CO}_{3}$ & 71 \\
\hline 3 & $\mathrm{~K}_{2} \mathrm{CO}_{3}$ & 0 \\
\hline 4 & $\mathrm{Na}_{2} \mathrm{CO}_{3}$ & 0 \\
\hline 5 & $\mathrm{~K}_{3} \mathrm{PO}_{4}$ & 39 \\
\hline 6 & $\mathrm{Na}_{3} \mathrm{PO}_{4}$ & 0 \\
\hline 7 & $\mathrm{~K}_{3} \mathrm{PO}_{4} \cdot 3 \mathrm{H}_{2} \mathrm{O}$ & $92(84)$ \\
\hline 8 & KOAc & 0 \\
\hline 9 & $\mathrm{NaOAc}$ & 0 \\
\hline 10 & $\mathrm{LiO}^{t} \mathrm{Bu}$ & 8 \\
\hline
\end{tabular}

Table S5. Effect of and the $\mathrm{K}_{3} \mathrm{PO}_{4} \cdot 3 \mathrm{H}_{2} \mathrm{O}$ and the Brettphos

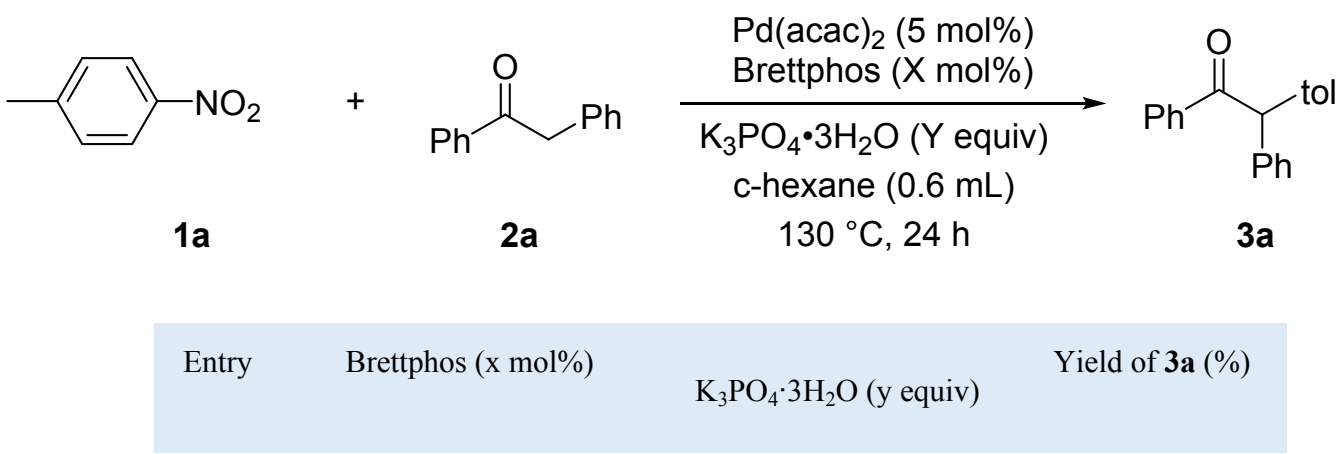




$\begin{array}{cccc}1 & 5 \mathrm{~mol} \% & 3 \text { equiv } & 45 \\ 2 & 10 \mathrm{~mol} \% & 3 \text { equiv } & 35 \\ 3 & 15 \mathrm{~mol} \% & 3 \text { equiv } & 60 \\ 4 & 20 \mathrm{~mol} \% & 3 \text { equiv } & \mathbf{9 2 ( 8 4 )} \\ 5 & 20 \mathrm{~mol} \% & 1 \text { equiv } & 58 \\ 6 & 20 \mathrm{~mol} \% & 2 \text { equiv } & 78 \\ 7 & 20 \mathrm{~mol} \% & 4 \text { equiv } & 82\end{array}$

Table S6. Optimization of the reaction conditions for the alfa-arylation of 1 a with $2 i$.

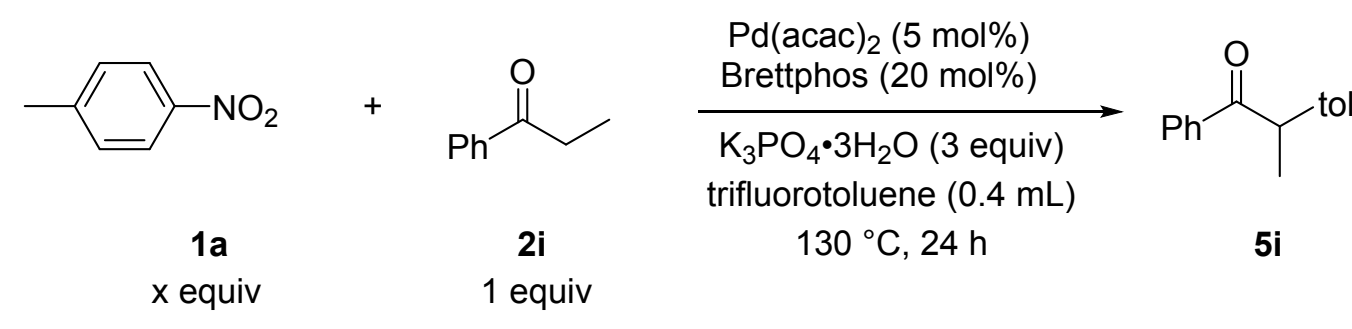

\begin{tabular}{|c|c|c|c|c|c|c|}
\hline Entry & $\begin{array}{c}\text { Palladium } \\
\text { catalyst }\end{array}$ & Ligand & Base & Solvent & addition & $\begin{array}{c}\text { Yield of } 3 \mathbf{a} \\
(\%)\end{array}$ \\
\hline 1 & $\operatorname{Pd}(\mathrm{acac})_{2}$ & Brettphos & $\mathrm{K}_{3} \mathrm{PO}_{4} \cdot 3 \mathrm{H}_{2} \mathrm{O}$ & Dioxane & - & 45 \\
\hline 2 & $\operatorname{Pd}(\mathrm{acac})_{2}$ & Brettphos & $\mathrm{K}_{3} \mathrm{PO}_{4} \cdot 3 \mathrm{H}_{2} \mathrm{O}$ & $\mathrm{THF}$ & - & 29 \\
\hline 3 & $\operatorname{Pd}(\mathrm{acac})_{2}$ & Brettphos & $\mathrm{K}_{3} \mathrm{PO}_{4} \cdot 3 \mathrm{H}_{2} \mathrm{O}$ & c-hexane & - & 31 \\
\hline 4 & $\operatorname{Pd}(\mathrm{acac})_{2}$ & Brettphos & $\mathrm{K}_{3} \mathrm{PO}_{4} \cdot 3 \mathrm{H}_{2} \mathrm{O}$ & n-hexane & - & 11 \\
\hline 5 & $\operatorname{Pd}(\mathrm{acac})_{2}$ & Brettphos & $\mathrm{K}_{3} \mathrm{PO}_{4} \cdot 3 \mathrm{H}_{2} \mathrm{O}$ & n-heptane & - & 13 \\
\hline 6 & $\operatorname{Pd}(\mathrm{acac})_{2}$ & Brettphos & $\mathrm{K}_{3} \mathrm{PO}_{4} \cdot 3 \mathrm{H}_{2} \mathrm{O}$ & Toluene & - & 48 \\
\hline 7 & $\operatorname{Pd}(\mathrm{acac})_{2}$ & Brettphos & $\mathrm{K}_{3} \mathrm{PO}_{4} \cdot 3 \mathrm{H}_{2} \mathrm{O}$ & Xylene & - & 41 \\
\hline 8 & $\operatorname{Pd}(\mathrm{acac})_{2}$ & Brettphos & $\mathrm{K}_{3} \mathrm{PO}_{4} \cdot 3 \mathrm{H}_{2} \mathrm{O}$ & trifluorotoluene & - & 61 \\
\hline 9 & $\operatorname{Pd}(\mathrm{acac})_{2}$ & Brettphos & $\mathrm{K}_{3} \mathrm{PO}_{4} \cdot 3 \mathrm{H}_{2} \mathrm{O}$ & $\mathrm{Et}_{2} \mathrm{O}$ & - & 27 \\
\hline 10 & $\operatorname{Pd}(\mathrm{acac})_{2}$ & Brettphos & $\mathrm{K}_{3} \mathrm{PO}_{4}$ & Dioxane & - & 17 \\
\hline 11 & $\operatorname{Pd}(\mathrm{acac})_{2}$ & Brettphos & $\mathrm{Cs}_{2} \mathrm{CO}_{3}$ & Dioxane & - & 41 \\
\hline 12 & $\operatorname{Pd}(\mathrm{acac})_{2}$ & Brettphos & $\mathrm{CsF}$ & Dioxane & - & 17 \\
\hline 13 & $\operatorname{Pd}(\mathrm{oac})_{2}$ & Brettphos & $\mathrm{K}_{3} \mathrm{PO}_{4} \cdot 3 \mathrm{H}_{2} \mathrm{O}$ & Toluene & - & 16 \\
\hline 14 & $\mathrm{Pd}\left(\mathrm{CF}_{3} \mathrm{COO}\right)_{2}$ & Brettphos & $\mathrm{K}_{3} \mathrm{PO}_{4} \cdot 3 \mathrm{H}_{2} \mathrm{O}$ & Toluene & - & 7 \\
\hline 15 & $\mathrm{PdCl}_{2}\left(\mathrm{CH}_{2} \mathrm{CN}\right)_{2}$ & Brettphos & $\mathrm{K}_{3} \mathrm{PO}_{4} \cdot 3 \mathrm{H}_{2} \mathrm{O}$ & Toluene & - & 6 \\
\hline 16 & $\mathrm{PdCl}_{2}(\mathrm{PhCN})_{2}$ & Brettphos & $\mathrm{K}_{3} \mathrm{PO}_{4} \cdot 3 \mathrm{H}_{2} \mathrm{O}$ & Toluene & - & 6 \\
\hline
\end{tabular}




\begin{tabular}{|c|c|c|c|c|c|}
\hline 17 & $\operatorname{Pd}(\mathrm{acac})_{2}$ & Brettphos & $\mathrm{K}_{3} \mathrm{PO}_{4} \cdot 3 \mathrm{H}_{2} \mathrm{O}$ & trifluorotoluene & $\begin{array}{c}\text { 3A Molecular } \\
\text { sieve }\end{array}$ \\
\hline 18 & $\operatorname{Pd}(\mathrm{acac})_{2}$ & Brettphos & $\mathrm{K}_{3} \mathrm{PO}_{4} \cdot 3 \mathrm{H}_{2} \mathrm{O}$ & trifluorotoluene & $\begin{array}{c}\text { 4A Molecular } \\
\text { sieve }\end{array}$ \\
\hline 19 & $\operatorname{Pd}(\mathrm{acac})_{2}$ & Brettphos & $\mathrm{K}_{3} \mathrm{PO}_{4} \cdot 3 \mathrm{H}_{2} \mathrm{O}$ & trifluorotoluene & $\begin{array}{c}\text { 5A Molecular } \\
\text { sieve }\end{array}$ \\
\hline 20 & $\operatorname{Pd}(\mathrm{acac})_{2}$ & Brettphos & $\mathrm{K}_{3} \mathrm{PO}_{4} \cdot 3 \mathrm{H}_{2} \mathrm{O}$ & trifluorotoluene & $\mathrm{Na}_{2} \mathrm{SO}_{4}$ \\
\hline 21 & $\mathrm{Pd}(\mathrm{acac})_{2}$ & Brettphos & $\mathrm{K}_{3} \mathrm{PO}_{4} \cdot 3 \mathrm{H}_{2} \mathrm{O}$ & trifluorotoluene & $\mathrm{NaI}$ \\
\hline
\end{tabular}

Table S7. Optimization of the paranitrotoluene for the alfa-arylation of 1a with 2 i.

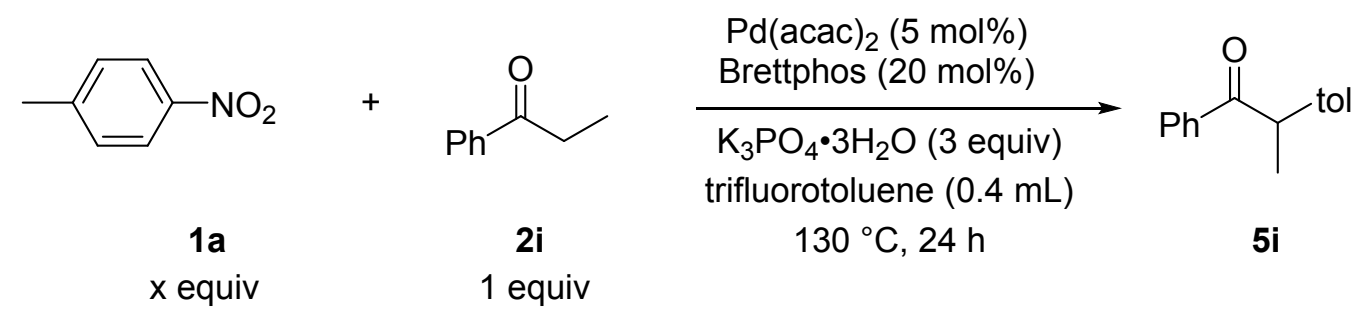

\begin{tabular}{|ccc|}
\hline Entry & 1a (x equiv) & Yield of $\mathbf{3 a}(\%)$ \\
1 & 1.5 equiv & 70 \\
2 & 2.0 equiv & 79 \\
3 & 2.5 equiv & 82 \\
4 & 3.0 equiv & $\mathbf{8 4 ( 8 2 )}$
\end{tabular}




\section{Functionalizations of Nitroarenes}

\section{The $1 \mathrm{mmol}$ scale reaction of the $\alpha$-arylation of ketones}

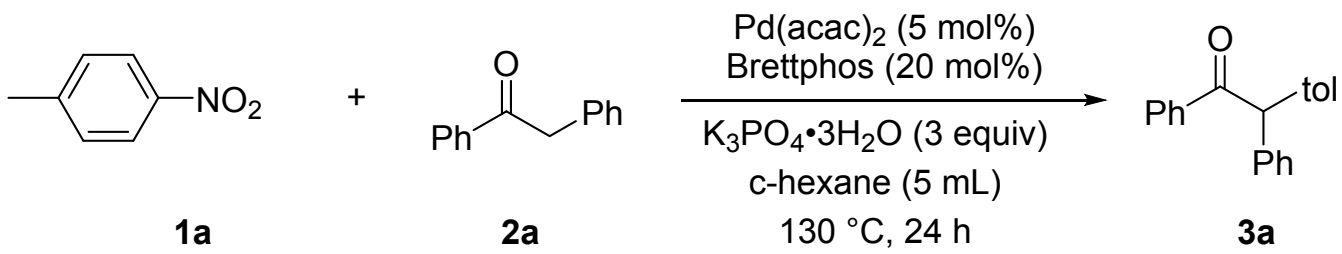

To an oven-dried tube equipped with a magnetic stirring bar were added sequentially nitroarene 1a (137 mg, $1 \mathrm{mmol})$, ketones $2 \mathrm{a}(235 \mathrm{mg}, 1.2 \mathrm{mmol}), \mathrm{Pd}(\mathrm{acac})_{2}(15 \mathrm{mg}, 0.05 \mathrm{mmol})$, Brettphos (107 mg, $0.2 \mathrm{mmol}$ ), $\mathrm{K}_{3} \mathrm{PO}_{4} \cdot 3 \mathrm{H}_{2} \mathrm{O}(800 \mathrm{mg}, 3 \mathrm{mmol})$, and cyclohexane $(5 \mathrm{~mL})$ under $\mathrm{N}_{2}$ atmosphere. The reaction mixture was stirred and heated at $130{ }^{\circ} \mathrm{C}$ for 24 hours. The reaction mixture was cooled to room temperature, and then it was passed through a short pad of silica gel with EtOAc. The solution was concentrated in vacuo. The residue was purified by silica gel column chromatography to give the product $\mathbf{3 a}$ as a white solid $(231.7 \mathrm{mg}, 81 \%$ yield).

\section{Trial of intramolecular type of denitrative $\alpha$-arylation of ketones}<smiles>O=C(CCCOc1ccccc1[N+](=O)[O-])c1ccccc1</smiles>

7

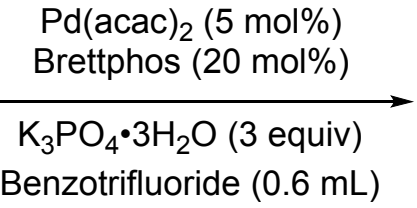

$130{ }^{\circ} \mathrm{C}, 24 \mathrm{~h}$<smiles>O=C(c1ccccc1)C1CCOc2ccccc21</smiles>

$851 \%$ yeild

To an oven-dried tube equipped with a magnetic stirring bar were added $7(28.5 \mathrm{mg}, 0.1 \mathrm{mmol})$, $\mathrm{Pd}(\mathrm{acac})_{2}(1.5 \mathrm{mg}, 0.005 \mathrm{mmol})$, Brettphos (10.7 mg, $\left.0.02 \mathrm{mmol}\right), \mathrm{K}_{3} \mathrm{PO}_{4} \cdot 3 \mathrm{H}_{2} \mathrm{O}(80 \mathrm{mg}, 0.3 \mathrm{mmol})$, and trifluorotoluene $(0.6 \mathrm{~mL})$ under $\mathrm{N}_{2}$ atmosphere. The reaction mixture was stirred and heated at $130{ }^{\circ} \mathrm{C}$ for 24 hours. The reaction mixture was cooled to room temperature, and then it was passed 
through a short pad of silica gel with EtOAc. The solution was concentrated in vacuo. The residue was purified by silica gel column chromatography to give the product 8 as a white solid $(24.1 \mathrm{mg}$, $51 \%$ yield) (two runs).

\section{3. "One portion" $S_{N} A r /$ Denitrative Arylation of Ketones with nitrobenzene}

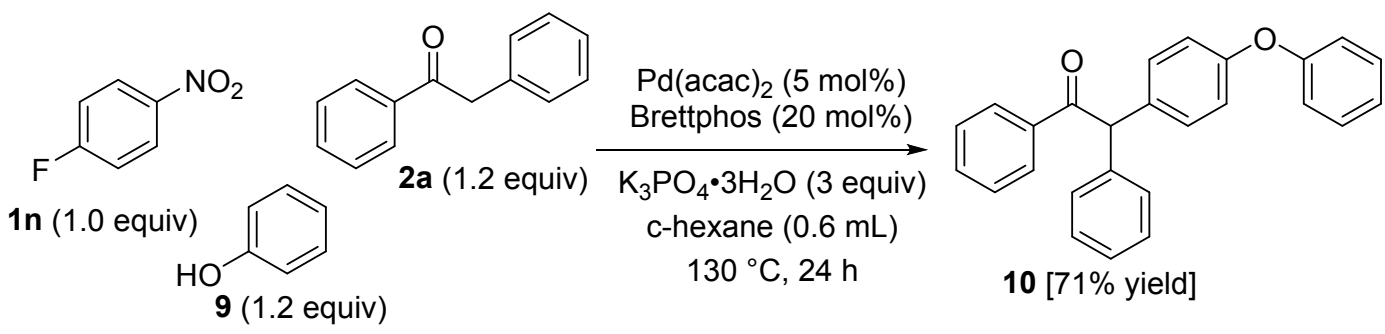

"One portion": To an oven-dried tube equipped with a magnetic stirring bar were added 4Fluoronitrobenzene 1n (15.7mg, $0.1 \mathrm{mmol})$, ketones 2a (23.5 mg, $0.12 \mathrm{mmol})$, phenol 9 (11.3 mg, $0.12 \mathrm{mmol}), \mathrm{Pd}(\mathrm{acac})_{2}(1.5 \mathrm{mg}, 0.005 \mathrm{mmol})$, Brettphos (10.7 mg, $\left.0.02 \mathrm{mmol}\right), \mathrm{K}_{3} \mathrm{PO}_{4} \cdot 3 \mathrm{H}_{2} \mathrm{O}(80$ $\mathrm{mg}, 0.3 \mathrm{mmol})$, and cyclohexane $(0.6 \mathrm{~mL})$ under $\mathrm{N}_{2}$ atmosphere. The reaction mixture was stirred and heated at $130^{\circ} \mathrm{C}$ for 24 hours. The reaction mixture was cooled to room temperature, and then it was passed through a short pad of silica gel with EtOAc. The solution was concentrated in vacuo. The residue was purified by silica gel column chromatography to give the product $\mathbf{1 0}$ as a yellow oil (51.9 mg, 71\% yield) (two runs).

\section{4. "Stepwise" or "one portion" Cross-Coupling Arylation/ Denitrative Arylation of Ketones}

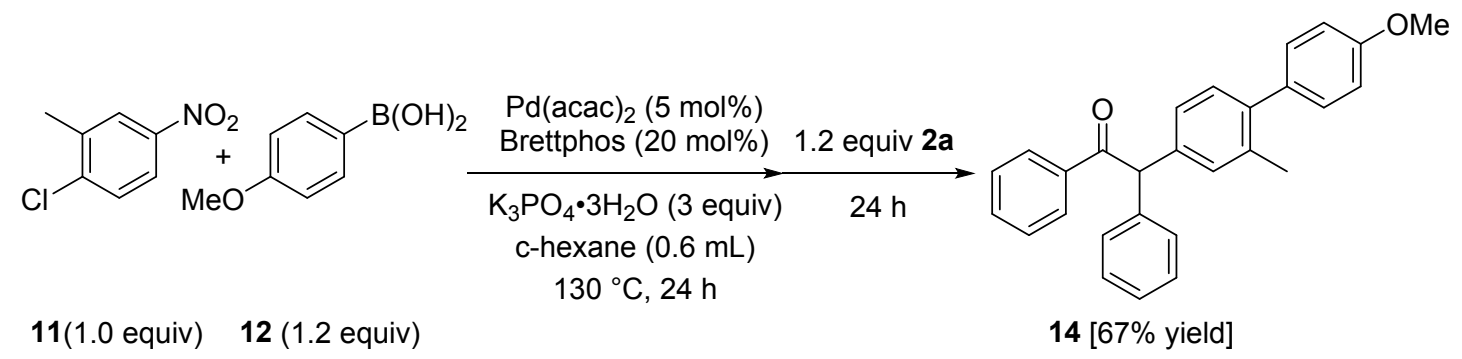

"stepwise": To an oven-dried tube equipped with a magnetic stirring bar were added sequentially nitroarene $11(17.1 \mathrm{mg}, 0.1 \mathrm{mmol})$, phenylboronic acid $12(18.2 \mathrm{mg}, 0.12 \mathrm{mmol})$, $\mathrm{Pd}(\mathrm{acac})_{2}(1.5 \mathrm{mg}, 0.005 \mathrm{mmol})$, Brettphos (10.7 mg, $\left.0.02 \mathrm{mmol}\right), \mathrm{K}_{3} \mathrm{PO}_{4} \cdot 3 \mathrm{H}_{2} \mathrm{O}(80 \mathrm{mg}, 0.3 \mathrm{mmol})$, and cyclohexane $(0.6 \mathrm{~mL})$ under $\mathrm{N}_{2}$ atmosphere. The reaction mixture was stirred and heated at 130 ${ }^{\circ} \mathrm{C}$ for 24 hours. The reaction mixture was cooled to room temperature, and added ketones $2 \mathbf{a}(23.5$ $\mathrm{mg}, 0.12 \mathrm{mmol}$ ) under $\mathrm{N} 2$ atmosphere, then the reaction mixture was stirred and heated at $130^{\circ} \mathrm{C}$ for 24 hours again. The reaction mixture was cooled to room temperature, and then it was passed through a short pad of silica gel with EtOAc. The solution was concentrated in vacuo. The residue was purified by silica gel column chromatography to give the product 14 as a white solid $(52.5 \mathrm{mg}$, 
<smiles>Cc1cc([N+](=O)[O-])ccc1Cl</smiles><smiles>[14CH3]</smiles><smiles>COc1ccc(Br)cc1C(=O)O[Na]</smiles><smiles>O=C(Cc1ccccc1)c1ccccc1</smiles>

2a a (1.2 equiv) Brettphos $(20 \mathrm{~mol} \%)$

$\mathrm{K}_{3} \mathrm{PO}_{4} \cdot 3 \mathrm{H}_{2} \mathrm{O}$ (3 equiv) c-hexane $(0.6 \mathrm{~mL})$ $130^{\circ} \mathrm{C}, 24 \mathrm{~h}$<smiles>COc1ccc(-c2ccc(C(C(=O)c3ccccc3)c3ccccc3)cc2C)cc1</smiles>

"One portion": To an oven-dried tube equipped with a magnetic stirring bar were added sequentially nitroarene 11 (17.1 $\mathrm{mg}, 0.1 \mathrm{mmol})$, ketones $\mathbf{2 a}(23.5 \mathrm{mg}, 0.12 \mathrm{mmol})$, phenylboronic acid 12 (18.2 mg, $0.12 \mathrm{mmol}), \mathrm{Pd}(\mathrm{acac})_{2}(1.5 \mathrm{mg}, 0.005 \mathrm{mmol})$, Brettphos (10.7 mg, $0.02 \mathrm{mmol}), \mathrm{K}_{3} \mathrm{PO}_{4} \cdot 3 \mathrm{H}_{2} \mathrm{O}(80 \mathrm{mg}, 0.3 \mathrm{mmol})$, and cyclohexane $(0.6 \mathrm{~mL})$ under $\mathrm{N}_{2}$ atmosphere. The reaction mixture was stirred and heated at $130{ }^{\circ} \mathrm{C}$ for 24 hours. The reaction mixture was cooled to room temperature, and then it was passed through a short pad of silica gel with EtOAc. The solution was concentrated in vacuo. The residue was purified by silica gel column chromatography to give the product $\mathbf{1 4}$ as a white solid (61.3 $\mathrm{mg}, 78 \%$ yield) (two runs).

\section{Kinetic Experiments}

Time course experiments.

To eight oven-dried tube equipped with a magnetic stirring bar were respectively added $\mathbf{1 b}$ (12.3 $\mathrm{mg}, 0.1 \mathrm{mmol}), 2 \mathrm{a}(23.5 \mathrm{mg}, 0.12 \mathrm{mmol}), \mathrm{Pd}(\mathrm{acac})_{2}(1.5 \mathrm{mg}, 0.005 \mathrm{mmol})$, Brettphos (10.7 mg, $0.02 \mathrm{mmol}), \mathrm{K}_{3} \mathrm{PO}_{4} \cdot 3 \mathrm{H}_{2} \mathrm{O}(80 \mathrm{mg}, 0.3 \mathrm{mmol})$, and cyclohexane $(0.6 \mathrm{~mL})$ under $\mathrm{N}_{2}$ atmosphere. The reaction mixture was stirred and heated respectively at $130^{\circ} \mathrm{C}$ for $10,20,30,40,50,90,150,240$ min. The recovery of $\mathbf{1 b}$ was given the GC yields. Each reaction is taken twice and averaged.

\begin{tabular}{cccccccccc} 
Time $/ \min$ & 0 & 10 & 20 & 30 & 40 & 50 & 90 & 150 & 240 \\
\hline $\mathrm{b} / \mathrm{mol} \cdot \mathrm{L}^{-1}$ & 0.1667 & 0.1333 & 0.12 & 0.1016 & 0.0933 & 0.07 & 0.0516 & 0.0417 & 0.0183
\end{tabular}




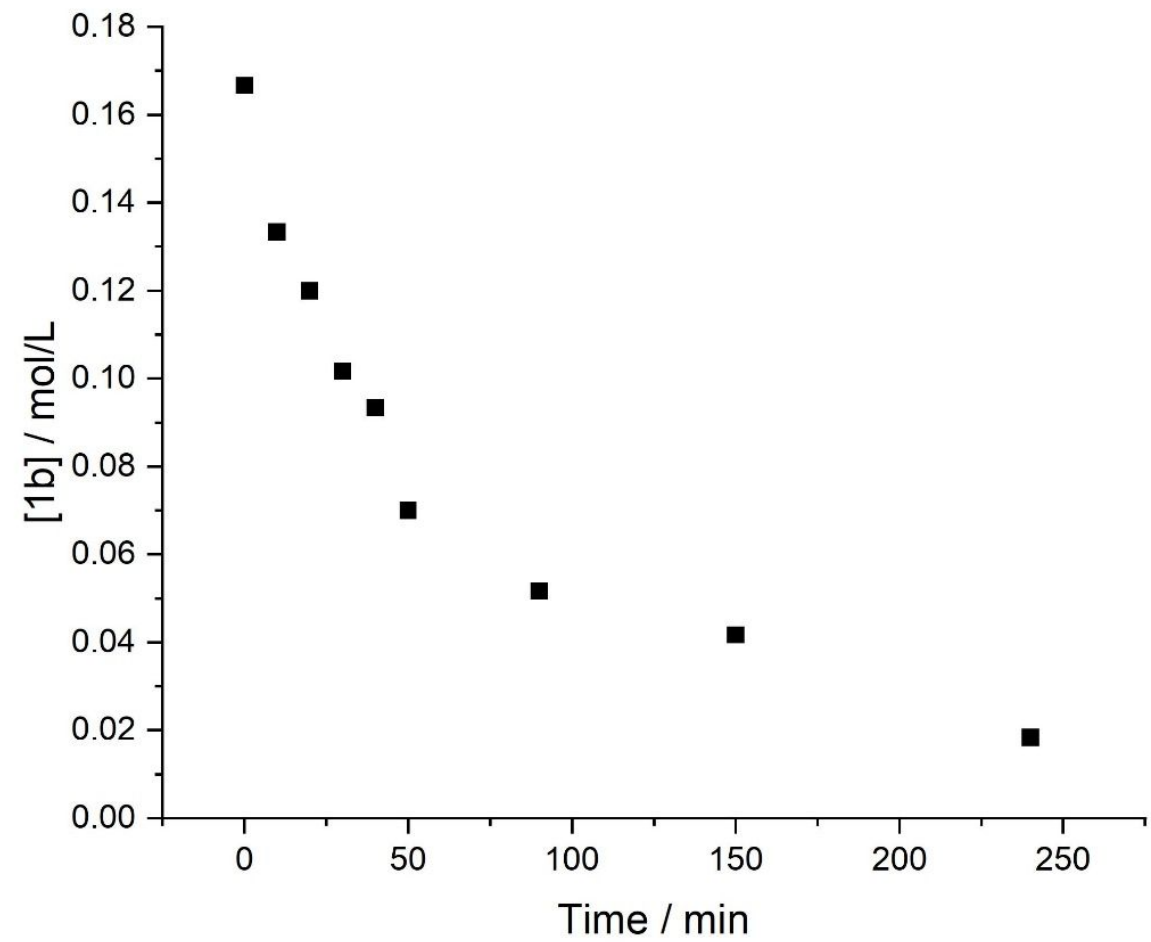

Kinetic Experiments

A.<smiles>[R]c1ccc([N+](=O)[O-])cc1</smiles>

1<smiles>O=C(Cc1ccccc1)c1ccccc1</smiles>

2a

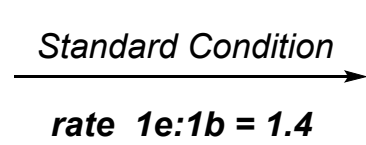

rate $1 e: 1 b=1.4$<smiles>[R]c1ccc(C(C(=O)c2ccccc2)c2ccccc2)cc1</smiles>

3

To five oven-dried tube equipped with a magnetic stirring bar were respectively added $\mathbf{1 b}$ (12.3 $\mathrm{mg}, 0.1 \mathrm{mmol})$ or 1 e $(15.3 \mathrm{mg}, 0.1 \mathrm{mmol}), 2 \mathrm{a}(23.5 \mathrm{mg}, 0.12 \mathrm{mmol}), \mathrm{Pd}(\mathrm{acac})_{2}(1.5 \mathrm{mg}, 0.005$ mmol), Brettphos (10.7 mg, $0.02 \mathrm{mmol}), \mathrm{K}_{3} \mathrm{PO}_{4} \cdot 3 \mathrm{H}_{2} \mathrm{O}(80 \mathrm{mg}, 0.3 \mathrm{mmol})$, and cyclohexane (0.6 $\mathrm{mL}$ ) under $\mathrm{N}_{2}$ atmosphere. The reaction mixture was stirred and heated respectively at $130{ }^{\circ} \mathrm{C}$ for $10,20,30,40,50 \mathrm{~min}$. The recovery of $\mathbf{1 b}$ or $\mathbf{1 e}$ was given the GC yields. Each reaction is taken twice and averaged to give $\mathbf{1 e} / \mathbf{1} \mathbf{b}=\mathbf{1} / \mathbf{1 . 4}$.

\begin{tabular}{ccccccc} 
Time $/ \min$ & 0 & 10 & 20 & 30 & 40 & 50 \\
\hline $\mathrm{lb} / \mathrm{mol} \cdot \mathrm{L}^{-1}$ & 0.1667 & 0.1333 & 0.12 & 0.1016 & 0.0933 & 0.07
\end{tabular}




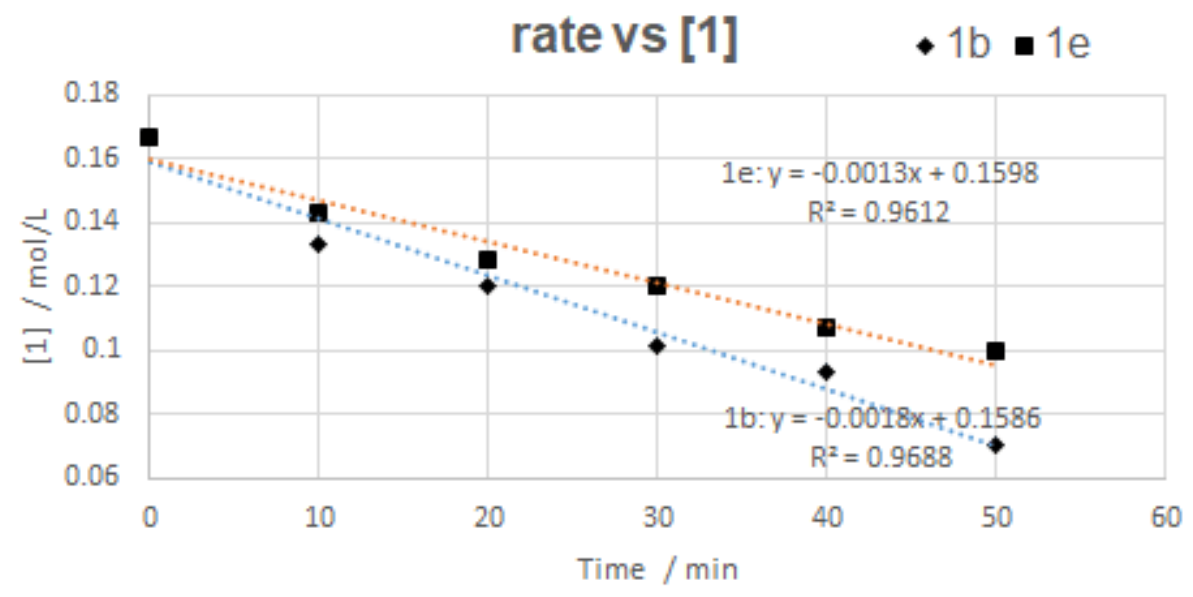

B1.<smiles>Cc1ccc([N+](=O)[O-])cc1</smiles>

$1 a$<smiles>O=C([Al])Cc1ccccc1</smiles>

4

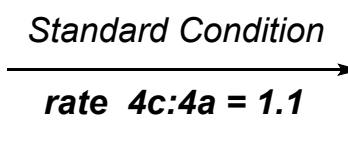

rate $4 c: 4 a=1.1$<smiles>CCC(=O)[C@H](c1ccccc1)c1ccc(C)cc1</smiles>

5

To five oven-dried tube equipped with a magnetic stirring bar were added $\mathbf{1 a}(13.7 \mathrm{mg}, 0.1 \mathrm{mmol})$, 4a $(25.2 \mathrm{mg}, 0.12 \mathrm{mmol})$ or $4 \mathbf{c}(25.6 \mathrm{mg}, 0.12 \mathrm{mmol}), \mathrm{Pd}(\mathrm{acac})_{2}(1.5 \mathrm{mg}, 0.005 \mathrm{mmol})$, Brettphos (10.7 mg, $0.02 \mathrm{mmol}), \mathrm{K}_{3} \mathrm{PO}_{4} \cdot 3 \mathrm{H}_{2} \mathrm{O}(80 \mathrm{mg}, 0.3 \mathrm{mmol})$, and cyclohexane $(0.6 \mathrm{~mL})$ under $\mathrm{N}_{2}$ atmosphere. The reaction mixture was stirred and heated respectively at $130{ }^{\circ} \mathrm{C}$ for $10,20,30,40$, $50 \mathrm{~min}$. The recovery of $\mathbf{4 a}$ or $\mathbf{4} \mathbf{c}$ was given the GC yields. Each reaction is taken twice and averaged to give $\mathbf{4 a} / \mathbf{4} \mathbf{c}=\mathbf{1} / \mathbf{1 . 1}$.

$\begin{array}{ccccccc}\text { Time } / \min & 0 & 10 & 20 & 30 & 40 & 50 \\ 4 \mathrm{a} / \mathrm{mol} \cdot \mathrm{L}^{-1} & 0.1667 & 0.1617 & 0.1433 & 0.13 & 0.11 & 0.09 \\ & & & & & & \\ 4 \mathrm{c} / \mathrm{mol} \cdot \mathrm{L}^{-1} & 0.1667 & 0.1583 & 0.1333 & 0.115 & 0.095 & 0.085\end{array}$




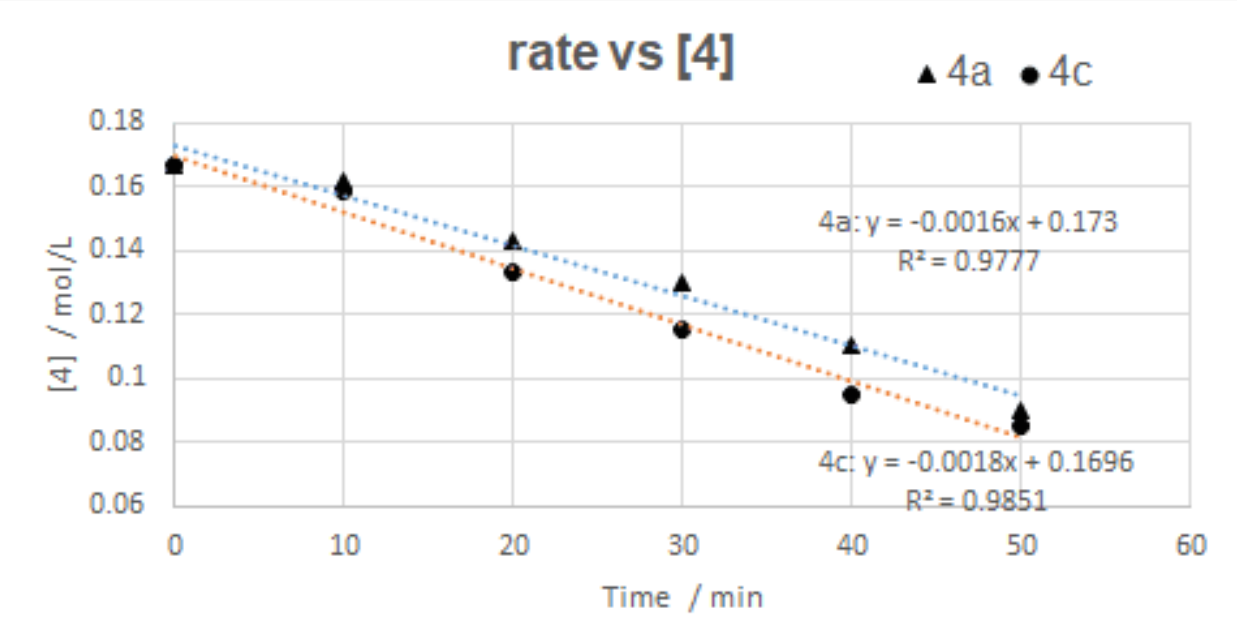

B2.<smiles></smiles>

To five oven-dried tube equipped with a magnetic stirring bar were added $1 \mathbf{a}(6.9 \mathrm{mg}, 0.05 \mathrm{mmol})$, 2a (11.9 mg, $0.06 \mathrm{mmol})$ or $\mathbf{4 h}(12.8 \mathrm{mg}, 0.06 \mathrm{mmol}), \mathrm{Pd}(\mathrm{acac})_{2}(0.8 \mathrm{mg}, 0.0025 \mathrm{mmol})$, Brettphos (5.4 mg, $0.01 \mathrm{mmol}), \mathrm{K}_{3} \mathrm{PO}_{4} \cdot 3 \mathrm{H}_{2} \mathrm{O}(40 \mathrm{mg}, 0.15 \mathrm{mmol})$, and cyclohexane $(0.4 \mathrm{~mL})$ under $\mathrm{N}_{2}$ atmosphere. The reaction mixture was stirred and heated respectively at $130{ }^{\circ} \mathrm{C}$ for $10,20,30,40$, $50 \mathrm{~min}$. The recovery of $\mathbf{2 a}$ or $\mathbf{4 h}$ was given the GC yields. Each reaction is taken twice and averaged to give $\mathbf{2} \mathbf{a} / \mathbf{4 h}=\mathbf{1} / \mathbf{1}$.

$\begin{array}{ccccccc}\text { Time } / \mathrm{min} & 0 & 10 & 20 & 30 & 40 & 50 \\ \mathrm{2a} / \mathrm{mol} \cdot \mathrm{L}^{-1} & 0.125 & 0.1138 & 0.11 & 0.1063 & 0.0975 & 0.0863 \\ & & & & & \\ \mathrm{4h} / \mathrm{mol} \cdot \mathrm{L}^{-1} & 0.125 & 0.115 & 0.105 & 0.115 & 0.0988 & 0.0963\end{array}$




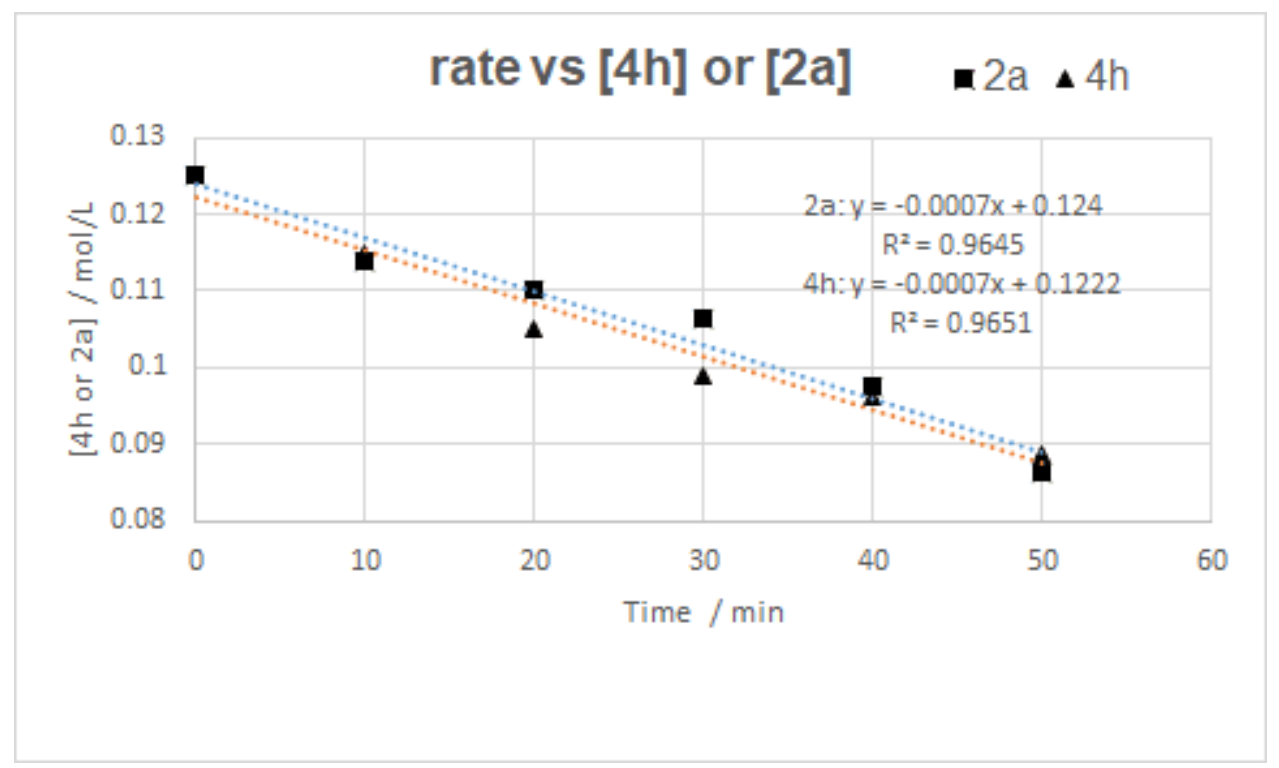




\section{VI. ${ }^{1} \mathrm{H}$ and ${ }^{13} \mathrm{C}$ NMR Spectra}<smiles>Cc1ccc(C(C(=O)c2ccccc2)c2ccccc2)cc1</smiles>

3a

The title compound was obtained in $84 \%$ ( $48.1 \mathrm{mg}$ ) yield according to Procedure A, white solid. ${ }^{1} \mathrm{H} \mathrm{NMR}\left(400 \mathrm{MHz}, \mathrm{CDCl}_{3}\right) \delta 8.00(\mathrm{~d}, \mathrm{~J}=8 \mathrm{~Hz}, 2 \mathrm{H}), 7.51(\mathrm{t}, \mathrm{J}=8 \mathrm{~Hz}, 1 \mathrm{H}), 7.40(\mathrm{t}, \mathrm{J}=8 \mathrm{~Hz}, 2 \mathrm{H})$, 7.33-7.20 (m, 5H), 7.18-7.12 (m, 4H), $6.00(\mathrm{~s}, 1 \mathrm{H}), 2.31(\mathrm{~s}, 3 \mathrm{H})$.

${ }^{13} \mathrm{C}$ NMR $\left(100 \mathrm{MHz}, \mathrm{CDCl}_{3}\right) \delta 198.3,139.3,136.8,136.0,133.0,129.4,129.1,129.0,128.95$, 128.93, 128.64, 128.56, 127.0, 59.1, 21.0.

The spectra are in accordance with those of the compound reported in the literature 5 .<smiles>O=C(c1ccccc1)C(c1ccccc1)c1ccccc1</smiles>

3b

The title compound was obtained in $88 \%(47.9 \mathrm{mg})$ yield according to Procedure A, white solid. ${ }^{1} \mathrm{H}$ NMR (400 MHz, CDCl $) \delta 8.00(\mathrm{~d}, \mathrm{~J}=8 \mathrm{~Hz}, 2 \mathrm{H}), 7.51(\mathrm{t}, \mathrm{J}=6 \mathrm{~Hz}, 1 \mathrm{H}), 7.41(\mathrm{t}, \mathrm{J}=8 \mathrm{~Hz}, 2 \mathrm{H})$, 7.34-7.23 (m, 10H), $6.04(\mathrm{~s}, 1 \mathrm{H})$.

${ }^{13} \mathrm{C}$ NMR $\left(100 \mathrm{MHz}, \mathrm{CDCl}_{3}\right) \delta 198.2,139.0,136.8,133.0,129.1,128.9,128.7,128.6,127.1,59.4$. The spectra are in accordance with those of the compound reported in the literature 5 .<smiles>Cc1ccccc1C(C(=O)c1ccccc1)c1ccccc1</smiles>

$3 \mathbf{c}$

The title compound was obtained in $86 \%$ yield $(49.2 \mathrm{mg}$ ) according to Procedure $\mathrm{A}$, colorless oil. ${ }^{1} \mathrm{H}$ NMR (400 MHz, CDCl $) \delta 7.93(\mathrm{~d}, \mathrm{~J}=8 \mathrm{~Hz}, 2 \mathrm{H}), 7.49(\mathrm{t}, \mathrm{J}=6 \mathrm{~Hz}, 1 \mathrm{H}), 7.39(\mathrm{t}, \mathrm{J}=8 \mathrm{~Hz}, 2 \mathrm{H})$, $7.32(\mathrm{t}, \mathrm{J}=8 \mathrm{~Hz}, 2 \mathrm{H}), 7.27-7.10(\mathrm{~m}, 6 \mathrm{H}), 7.04(\mathrm{~d}, \mathrm{~J}=8 \mathrm{~Hz}, 1 \mathrm{H}), 6.12(\mathrm{~s}, 1 \mathrm{H}), 2.33$ (s, 3H).

${ }^{13} \mathrm{C}$ NMR $\left(100 \mathrm{MHz}, \mathrm{CDCl}_{3}\right) \delta 198.5,137.8,137.5,136.7,135.8,132.9,130.8,129.6,128.79$, $128.76,128.59,128.57,127.3,127.1,126.3,56.6,20.1$.

The spectra are in accordance with those of the compound reported in the literature 5 . 
<smiles>Cc1cccc(C(C(=O)c2ccccc2)c2ccccc2)c1</smiles>

3d

The title compound was obtained in $97 \%$ (55.6 mg) yield according to Procedure A, white solid. ${ }^{1} \mathrm{H} \mathrm{NMR}\left(400 \mathrm{MHz}, \mathrm{CDCl}_{3}\right) \delta 8.00(\mathrm{~d}, \mathrm{~J}=8 \mathrm{~Hz}, 2 \mathrm{H}), 7.51(\mathrm{t}, \mathrm{J}=8 \mathrm{~Hz}, 1 \mathrm{H}), 7.41(\mathrm{t}, \mathrm{J}=8 \mathrm{~Hz}, 2 \mathrm{H})$, $7.32(\mathrm{t}, \mathrm{J}=8 \mathrm{~Hz}, 2 \mathrm{H}), 7.28-7.19(\mathrm{~m}, 5 \mathrm{H}), 7.07$ (dd, J = 8 Hz, 2H), $6.00(\mathrm{~s}, 1 \mathrm{H}), 2.31(\mathrm{~s}, 3 \mathrm{H})$.

${ }^{13} \mathrm{C}$ NMR $\left(100 \mathrm{MHz}, \mathrm{CDCl}_{3}\right) \delta 198.3,139.1,138.9,138.4,136.8,133.0,129.8,129.1,128.9,128.7$, $128.64,128.58,128.0,127.1,126.2,59.4,21.5$.

The spectra are in accordance with those of the compound reported in the literature ${ }^{5}$.<smiles>COc1ccc(C(C(=O)c2ccccc2)c2ccccc2)cc1</smiles>

$3 \mathbf{e}$

The title compound was obtained in $89 \%$ (53.8 mg) yield according to Procedure A, white solid. ${ }^{1} \mathrm{H}$ NMR (400 MHz, CDCl $) \delta 8.00(\mathrm{~d}, \mathrm{~J}=8 \mathrm{~Hz}, 2 \mathrm{H}), 7.51(\mathrm{t}, \mathrm{J}=8 \mathrm{~Hz}, 1 \mathrm{H}), 7.41(\mathrm{t}, \mathrm{J}=8 \mathrm{~Hz}, 2 \mathrm{H})$, $7.32(\mathrm{t}, \mathrm{J}=8 \mathrm{~Hz}, 2 \mathrm{H}), 7.28-7.16(\mathrm{~m}, 5 \mathrm{H}), 6.86(\mathrm{~d}, \mathrm{~J}=8 \mathrm{~Hz}, 2 \mathrm{H}), 5.99(\mathrm{~s}, 1 \mathrm{H}), 3.77(\mathrm{~s}, 3 \mathrm{H})$. ${ }^{13} \mathrm{C}$ NMR $\left(100 \mathrm{MHz}, \mathrm{CDCl}_{3}\right) \delta 198.5,158.6,139.4,136.8,133.0,131.1,130.1,129.0,128.9,128.7$, 128.6, 127.0, 114.1, 58.6, 55.2.

The spectra are in accordance with those of the compound reported in the literature 5 .<smiles>COc1ccccc1C(C(=O)c1ccccc1)c1ccccc1</smiles>

3f

The title compound was obtained in $94 \%$ (56.8 mg) yield according to Procedure A, white solid. ${ }^{1} \mathrm{H}$ NMR $\left(400 \mathrm{MHz}, \mathrm{CDCl}_{3}\right) \delta 8.01(\mathrm{~d}, \mathrm{~J}=8 \mathrm{~Hz}, 2 \mathrm{H}), 7.49(\mathrm{t}, \mathrm{J}=8 \mathrm{~Hz}, 1 \mathrm{H}), 7.45-7.20(\mathrm{~m}, 8 \mathrm{H})$, 6.94-6.84 (m, 3H), $6.33(\mathrm{~s}, 1 \mathrm{H}), 3.77(\mathrm{~s}, 3 \mathrm{H})$.

${ }^{13} \mathrm{C}$ NMR $\left(100 \mathrm{MHz}, \mathrm{CDCl}_{3}\right) \delta 198.8,156.2,137.5,137.1,132.6,129.7,128.70,128.67,128.4$, 128.3, 127.1, 120.6, 110.4, 55.4, 53.0.

The spectra are in accordance with those of the compound reported in the literature 5 . 
<smiles>CC(C)(C)c1ccc(C(C(=O)c2ccccc2)c2ccccc2)cc1</smiles>

\section{$3 g$}

The title compound was obtained in $87 \%$ (57.1 mg) yield according to Procedure A, colorless oil. ${ }^{1} \mathrm{H} \mathrm{NMR}\left(400 \mathrm{MHz}, \mathrm{CDCl}_{3}\right) \delta 8.01(\mathrm{~d}, \mathrm{~J}=8 \mathrm{~Hz}, 2 \mathrm{H}), 7.49(\mathrm{t}, \mathrm{J}=8 \mathrm{~Hz}, 1 \mathrm{H}), 7.39(\mathrm{t}, \mathrm{J}=8 \mathrm{~Hz}, 2 \mathrm{H})$, 7.35-7.27 (m, 6H), 7.26-7.18 (m, 3H), $6.01(\mathrm{~s}, 1 \mathrm{H}), 1.28(\mathrm{~s}, 9 \mathrm{H})$.

${ }^{13} \mathrm{C}$ NMR $\left(100 \mathrm{MHz}, \mathrm{CDCl}_{3}\right) \delta 198.3,149.8,139.2,136.8,135.9,133.0,129.0,128.9,128.7,128.62$, $128.55,127.0,125.6,58.9,34.4,31.3$.

The spectra are in accordance with those of the compound reported in the literature 5 .<smiles>Cc1cc(C)cc(C(C(=O)c2ccccc2)c2ccccc2)c1</smiles>

\section{$3 \mathbf{h}$}

The title compound was obtained in $94 \%(52.2 \mathrm{mg})$ yield according to Procedure A, yellow oil.

${ }^{1} \mathrm{H}$ NMR (400 MHz, CDCl $) \delta 8.00(\mathrm{~d}, \mathrm{~J}=8 \mathrm{~Hz}, 2 \mathrm{H}), 7.51(\mathrm{t}, \mathrm{J}=8 \mathrm{~Hz}, 1 \mathrm{H}), 7.41(\mathrm{t}, \mathrm{J}=8 \mathrm{~Hz}, 2 \mathrm{H})$, 7.32 (t, J = $8 \mathrm{~Hz}, 2 \mathrm{H}), 7.29-7.20$ (m, 3H), 6.89 (s, 3H), 5.97 (s, 1H), 2.27 (s, 6H).

${ }^{13} \mathrm{C} \mathrm{NMR}\left(100 \mathrm{MHz}, \mathrm{CDCl}_{3}\right) \delta 198.4,139.2,138.7,138.2,136.9,133.0,129.1,129.0,128.9,128.60$, $128.57,127.0,126.8,59.4,21.3$.

The spectra are in accordance with those of the compound reported in the literature 5 .<smiles>O=C(c1ccccc1)C(c1ccccc1)c1ccc(-c2ccccc2)cc1</smiles>

$3 \mathbf{i}$

The title compound was obtained in $91 \%$ (63.4 mg) yield according to Procedure A, white solid. ${ }^{1} \mathrm{H}$ NMR (400 MHz, $\left.\mathrm{CDCl}_{3}\right) \delta 8.03$ (d, J = 8 Hz, 2H), 7.58-7.50 (m, 5H), 7.45-7.38 (m, 4H), 7.37$7.25(\mathrm{~m}, 8 \mathrm{H}), 6.08(\mathrm{~s}, 1 \mathrm{H})$.

${ }^{13} \mathrm{C}$ NMR (100 MHz, $\left.\mathrm{CDCl}_{3}\right) \delta 198.2,140.6,140.0,139.0,138.1,136.7,133.1,129.5,129.1,129.0$, $128.8,128.7,128.6,127.4,127.2,127.2,127.0,59.1$.

The spectra are in accordance with those of the compound reported in the literature 5 . 
<smiles>O=C(c1ccccc1)C(c1ccccc1)c1ccc(C(F)(F)F)cc1</smiles>

\section{3j}

The title compound was obtained in 55\% (37.4 mg) yield according to Procedure A, colorless oil. ${ }^{1} \mathrm{H}$ NMR (400 MHz, CDCl $) \delta 7.99(\mathrm{~d}, \mathrm{~J}=8 \mathrm{~Hz}, 2 \mathrm{H}), 7.60-7.50(\mathrm{~m}, 3 \mathrm{H}), 7.46-7.31(\mathrm{~m}, 6 \mathrm{H}), 7.30$ $7.24(\mathrm{~m}, 3 \mathrm{H}), 6.09(\mathrm{~s}, 1 \mathrm{H})$.

${ }^{13} \mathrm{C}$ NMR $\left(100 \mathrm{MHz}, \mathrm{CDCl}_{3}\right) \delta 197.5,143.1,138.1,136.3,133.4,129.6,129.1,129.0,128.7,127.6$, 125.6, 125.53, 125,49, 125.4, 59.1.

${ }^{19} \mathrm{~F}$ NMR $\left(376 \mathrm{MHz}, \mathrm{CDCl}_{3}\right) \delta-62.55$ (s, 3F).

The spectra are in accordance with those of the compound reported in the literature 5 .<smiles>CCOC(=O)c1ccc(C(C(=O)c2ccccc2)c2ccccc2)cc1</smiles>

$3 \mathbf{k}$

The title compound was obtained in $69 \%(47.5 \mathrm{mg})$ yield according to Procedure A, yellow oil. ${ }^{1} \mathrm{H} \mathrm{NMR}\left(400 \mathrm{MHz}, \mathrm{CDCl}_{3}\right) \delta$ 8.04-7.96 (m, 4H), $7.53(\mathrm{t}, \mathrm{J}=8 \mathrm{~Hz}, 1 \mathrm{H}), 7.42(\mathrm{t}, \mathrm{J}=8 \mathrm{~Hz}, 2 \mathrm{H}), 7.38$ $7.25(\mathrm{~m}, 7 \mathrm{H}), 6.08(\mathrm{~s}, 1 \mathrm{H}), 4.35(\mathrm{q}, \mathrm{J}=8 \mathrm{~Hz}, 2 \mathrm{H}), 1.36(\mathrm{t}, \mathrm{J}=6 \mathrm{~Hz}, 3 \mathrm{H})$.

${ }^{13} \mathrm{C}$ NMR $\left(100 \mathrm{MHz}, \mathrm{CDCl}_{3}\right) \delta 197.5,166.3,144.1,138.3,136.4,133.2,129.9,129.3,129.2,129.0$, $128.93,128.90,128.7,127.4,60.9,59.3,14.3$.

The spectra are in accordance with those of the compound reported in the literature ${ }^{5}$.<smiles>CC(=O)c1cccc(C(C(=O)c2ccccc2)c2ccccc2)c1</smiles>

31

The title compound was obtained in $92 \%$ (60.8 mg) yield according to Procedure A, white solid. ${ }^{1} \mathrm{H}$ NMR (400 MHz, $\left.\mathrm{CDCl}_{3}\right) \delta$ 8.05-7.91 (m, 4H), 7.55-7.45 (m, 2H), 7.44-7.37 (m, 3H), $7.34(\mathrm{t}, \mathrm{J}$ $=8 \mathrm{~Hz}, 2 \mathrm{H}), 7.31-7.25(\mathrm{~m}, 3 \mathrm{H}), 6.09(\mathrm{~s}, 1 \mathrm{H}), 3.88(\mathrm{~s}, 3 \mathrm{H})$.

${ }^{13} \mathrm{C}$ NMR $\left(100 \mathrm{MHz}, \mathrm{CDCl}_{3}\right) \delta 197.6,166.8,139.5,138.5,136.4,133.7,133.2,130.5,130.3,129.0$, 128.94, 128.92, 128.69, 128.65, 128.4, 127.4, 59.1, 52.1.

HRMS (M+Na) ${ }^{+}$: Calcd for $\mathrm{C}_{22} \mathrm{H}_{18} \mathrm{O}_{3} \mathrm{Na}: 353.1148$, found 353.1151 . 
<smiles>O=C(c1ccccc1)C(c1ccccc1)c1ccc(C2OCCO2)cc1</smiles>

\section{$3 \mathbf{m}$}

The title compound was obtained in 76\% (52.5 mg) yield according to Procedure A, yellow solid. ${ }^{1} \mathrm{H}$ NMR $\left(400 \mathrm{MHz}, \mathrm{CDCl}_{3}\right) \delta 7.99(\mathrm{~d}, \mathrm{~J}=8 \mathrm{~Hz}, 2 \mathrm{H}), 7.52-7.35(\mathrm{~m}, 5 \mathrm{H}), 7.34-7.21(\mathrm{~m}, 7 \mathrm{H}), 6.05$ (s, 1H), $5.78(\mathrm{~s}, 1 \mathrm{H}), 4.05(\mathrm{tt}, \mathrm{J}=10 \mathrm{~Hz}, 4 \mathrm{H})$.

${ }^{13} \mathrm{C}$ NMR $\left(100 \mathrm{MHz}, \mathrm{CDCl}_{3}\right) \delta 198.0,140.0,138.9,136.8,136.7,133.0,129.2,129.1,128.9,128.64$, $128.58,127.1,126.8,65.3,65.2,59.1$.

HRMS $(\mathrm{M}+\mathrm{Na})^{+}$: Calcd for $\mathrm{C}_{23} \mathrm{H}_{20} \mathrm{O}_{3} \mathrm{Na}: 367.1305$, found 367.1299 .<smiles>O=C(c1ccccc1)C(c1ccccc1)c1ccc(F)cc1</smiles>

\section{3n}

The title compound was obtained in $77 \%(44.7 \mathrm{mg}$ ) yield according to Procedure A, white solid. ${ }^{1} \mathrm{H} \mathrm{NMR}\left(400 \mathrm{MHz}, \mathrm{CDCl}_{3}\right) \delta 7.99(\mathrm{~d}, \mathrm{~J}=8 \mathrm{~Hz}, 2 \mathrm{H}), 7.53(\mathrm{t}, \mathrm{J}=8 \mathrm{~Hz}, 1 \mathrm{H}), 7.42(\mathrm{t}, \mathrm{J}=8 \mathrm{~Hz}, 2 \mathrm{H})$, $7.33(\mathrm{t}, \mathrm{J}=8 \mathrm{~Hz}, 2 \mathrm{H}), 7.30-7.20(\mathrm{~m}, 5 \mathrm{H}), 7.01(\mathrm{t}, \mathrm{J}=8 \mathrm{~Hz}, 2 \mathrm{H}), 6.02(\mathrm{~s}, 1 \mathrm{H})$.

${ }^{13} \mathrm{C}$ NMR $\left(100 \mathrm{MHz}, \mathrm{CDCl}_{3}\right) \delta 198.1,161.9(\mathrm{C}-\mathrm{F}, \mathrm{d}, \mathrm{J}=245 \mathrm{~Hz}), 138.8,136.5,130.7,130.6,128.94$, $128.88,128.7,127.3,115.6,115.4,58.5$.

${ }^{19} \mathrm{~F}$ NMR $\left(376 \mathrm{MHz}, \mathrm{CDCl}_{3}\right) \delta-115.64(\mathrm{~m}, 1 \mathrm{~F})$.

The spectra are in accordance with those of the compound reported in the literature 5 .<smiles>O=C(c1ccccc1)C(c1ccccc1)c1cccc(F)c1</smiles>

3o

The title compound was obtained in $82 \%$ ( $47.6 \mathrm{mg}$ ) yield according to Procedure A, white solid. ${ }^{1} \mathrm{H}$ NMR (400 MHz, CDCl $) \delta 7.99(\mathrm{~d}, \mathrm{~J}=8 \mathrm{~Hz}, 2 \mathrm{H}), 7.52(\mathrm{t}, \mathrm{J}=8 \mathrm{~Hz}, 1 \mathrm{H}), 7.41(\mathrm{t}, \mathrm{J}=8 \mathrm{~Hz}, 2 \mathrm{H})$, 7.36-7.24 (m, 6H), 7.05-6.92 (m, 3H), $6.03(\mathrm{~s}, 1 \mathrm{H})$.

${ }^{13} \mathrm{C}$ NMR $\left(100 \mathrm{MHz}, \mathrm{CDCl}_{3}\right) \delta$ 197.6, $162.9(\mathrm{C}-\mathrm{F}, \mathrm{d}, \mathrm{J}=245 \mathrm{~Hz}), 141.5(\mathrm{C}-\mathrm{F}, \mathrm{d}, \mathrm{J}=7 \mathrm{~Hz}), 138.3$, 136.4, 133.2, 130.0 (C-F, d, J = 8 Hz), 129.0, 128.93, 128.91, 128.7, 127.4, 124.8 (C-F, d, J = 3 Hz), $116.2(\mathrm{C}-\mathrm{F}, \mathrm{d}, \mathrm{J}=22 \mathrm{~Hz}), 114.1$ (C-F, d, J = 21 Hz), $58.9(\mathrm{C}-\mathrm{F}, \mathrm{d}, \mathrm{J}=1 \mathrm{~Hz})$.

${ }^{19} \mathrm{~F}$ NMR $\left(376 \mathrm{MHz}, \mathrm{CDCl}_{3}\right) \delta-112.69(\mathrm{~m}, 1 \mathrm{~F})$.

The spectra are in accordance with those of the compound reported in the literature 5 . 
<smiles>Cc1ccc(C(C(=O)c2ccccc2)c2ccccc2)cc1F</smiles>

\section{3p}

The title compound was obtained in $69 \%$ (42.0 mg) yield according to Procedure A, yellow oil. ${ }^{1} \mathrm{H}$ NMR (400 MHz, CDCl $) \delta 7.99(\mathrm{~d}, \mathrm{~J}=8 \mathrm{~Hz}, 2 \mathrm{H}), 7.51(\mathrm{t}, \mathrm{J}=8 \mathrm{~Hz}, 1 \mathrm{H}), 7.40(\mathrm{t}, \mathrm{J}=8 \mathrm{~Hz}, 2 \mathrm{H})$, 7.39-7.23 (m, 5H), $7.11(\mathrm{t}, \mathrm{J}=8 \mathrm{~Hz}, 1 \mathrm{H}), 6.93(\mathrm{t}, \mathrm{J}=8 \mathrm{~Hz}, 2 \mathrm{H}), 5.98(\mathrm{~s}, 1 \mathrm{H}), 2.22(\mathrm{~s}, 3 \mathrm{H})$.

${ }^{13} \mathrm{C}$ NMR $\left(100 \mathrm{MHz}, \mathrm{CDCl}_{3}\right) \delta 197.8,161.3(\mathrm{C}-\mathrm{F}, \mathrm{d}, \mathrm{J}=244 \mathrm{~Hz}), 138.6,136.6,134.9,133.1,131.5$ $(\mathrm{C}-\mathrm{F}, \mathrm{d}, \mathrm{J}=5 \mathrm{~Hz}), 129.0,128.9,128.8,128.6,127.3,124.4(\mathrm{~d}, \mathrm{~J}=3 \mathrm{~Hz}), 123.6$ (d, J = 17 Hz), 115.8 (d, J = $23 \mathrm{~Hz}), 58.7$ (C-F, d, J = 1 Hz), $14.2(\mathrm{C}-\mathrm{F}, \mathrm{d}, \mathrm{J}=4 \mathrm{~Hz})$.

${ }^{19} \mathrm{~F}$ NMR $\left(376 \mathrm{MHz}, \mathrm{CDCl}_{3}\right) \delta-116.88(\mathrm{~m}, 1 \mathrm{~F})$.

HRMS (M) ${ }^{+}$: Calcd for $\mathrm{C}_{21} \mathrm{H}_{17} \mathrm{FO}$ : 304.1258 , found 304.1259 .<smiles>O=C(c1ccccc1)C(c1ccccc1)c1ccc2ccccc2c1</smiles>

\section{$3 q$}

The title compound was obtained in $82 \%(52.8 \mathrm{mg})$ yield according to Procedure A, white solid. ${ }^{1} \mathrm{H}$ NMR (400 MHz, $\left.\left.\mathrm{CDCl}_{3}\right) \delta 8.04(\mathrm{~d}, \mathrm{~J}=8 \mathrm{~Hz}, 2 \mathrm{H}), 7.82-7.75(\mathrm{~m}, 3 \mathrm{H}), 7.70 \mathrm{~s}, 1 \mathrm{H}\right), 7.52-7.25(\mathrm{~m}$, $11 \mathrm{H}), 6.20(\mathrm{~s}, 1 \mathrm{H})$.

${ }^{13} \mathrm{C}$ NMR $\left(100 \mathrm{MHz}, \mathrm{CDCl}_{3}\right) \delta 198.2,139.0,136.8,136.6,133.4,133.0,132.5,129.3,129.0,128.7$, $128.6,128.5,127.9,127.7,127.6,127.3,127.2,126.1,125.9,59.5$

The spectra are in accordance with those of the compound reported in the literature ${ }^{5}$.<smiles>CCn1ccc2ccc(C(C(=O)c3ccccc3)c3ccccc3)cc21</smiles>

$3 \mathbf{r}$

The title compound was obtained in 62\% (42.1 mg) yield according to Procedure A, yellow solid. ${ }^{1} \mathrm{H}$ NMR $\left(400 \mathrm{MHz}, \mathrm{CDCl}_{3}\right) \delta 8.03(\mathrm{~d}, \mathrm{~J}=8 \mathrm{~Hz}, 2 \mathrm{H}), 7.58(\mathrm{~d}, \mathrm{~J}=8 \mathrm{~Hz}, 1 \mathrm{H}), 7.47(\mathrm{t}, \mathrm{J}=6 \mathrm{~Hz}, 1 \mathrm{H})$, $7.38(\mathrm{t}, \mathrm{J}=6 \mathrm{~Hz}, 2 \mathrm{H}), 7.35-7.20(\mathrm{~m}, 6 \mathrm{H}), 7.06(\mathrm{~d}, \mathrm{~J}=8 \mathrm{~Hz}, 2 \mathrm{H}), 6.44(\mathrm{~s}, 1 \mathrm{H}), 6.17(\mathrm{~s}, 1 \mathrm{H}), 4.08(\mathrm{q}$, $\mathrm{J}=8 \mathrm{~Hz}, 2 \mathrm{H}), 1.38(\mathrm{t}, \mathrm{J}=6 \mathrm{~Hz}, 3 \mathrm{H})$.

${ }^{13} \mathrm{C}$ NMR $\left(100 \mathrm{MHz}, \mathrm{CDCl}_{3}\right) \delta 198.8,140.0,137.2,136.1,132.8,132.0,129.2,129.0,128.5,128.4$, 127.7, 127.3, 126.9, 121.4, 121.0, 109.6, 100.9, 59.8, 40.8, 15.3.

HRMS $(\mathrm{M}+\mathrm{Na})^{+}$: Calcd for $\mathrm{C}_{24} \mathrm{H}_{21} \mathrm{NONa}: 362.1515$, found 362.1511 . 
<smiles>CCn1ncc2ccc(C(C(=O)c3ccccc3)c3ccccc3)cc21</smiles>

$3 s$

The title compound was obtained in $60 \%$ ( $40.9 \mathrm{mg}$ ) yield according to Procedure A, yellow solid. ${ }^{1} \mathrm{H} \mathrm{NMR}\left(400 \mathrm{MHz}, \mathrm{CDCl}_{3}\right) \delta 8.03(\mathrm{~d}, \mathrm{~J}=8 \mathrm{~Hz}, 2 \mathrm{H}), 7.95(\mathrm{~s}, 1 \mathrm{H}), 7.67(\mathrm{~d}, \mathrm{~J}=8 \mathrm{~Hz}, 1 \mathrm{H}), 7.53(\mathrm{t}, \mathrm{J}$ $=8 \mathrm{~Hz}, 1 \mathrm{H}), 7.42(\mathrm{t}, \mathrm{J}=8 \mathrm{~Hz}, 2 \mathrm{H}), 7.36-7.22(\mathrm{~m}, 5 \mathrm{H}), 7.10(\mathrm{~d}, \mathrm{~J}=8 \mathrm{~Hz}, 1 \mathrm{H}), 6.20(\mathrm{~s}, 1 \mathrm{H}), 4.36(\mathrm{q}$, $\mathrm{J}=8 \mathrm{~Hz}, 2 \mathrm{H}), 1.46(\mathrm{t}, \mathrm{J}=6 \mathrm{~Hz}, 3 \mathrm{H})$.

${ }^{13} \mathrm{C}$ NMR $\left(100 \mathrm{MHz}, \mathrm{CDCl}_{3}\right) \delta 198.2,139.3,138.9,137.3,136.8,133.1,132.5,129.1,128.9,128.7$, 128.6, 127.2, 123.2, 122.4, 121.4, 109.0, 59.6, 43.5, 14.8 .

HRMS (M+Na) : Calcd for $\mathrm{C}_{23} \mathrm{H}_{20} \mathrm{~N}_{2} \mathrm{ONa}: 363.1468$, found 363.1462 .<smiles>COc1ccc(C(=O)C(c2ccccc2)c2ccc(C)cc2)cc1</smiles>

\section{$5 \mathbf{a}$}

The title compound was obtained in $80 \%$ (50.6 mg) yield according to Procedure A, white solid. ${ }^{1} \mathrm{H}$ NMR (400 MHz, $\left.\mathrm{CDCl}_{3}\right) \delta 7.98(\mathrm{~d}, \mathrm{~J}=12 \mathrm{~Hz}, 2 \mathrm{H}), 7.32-7.20(\mathrm{~m}, 5 \mathrm{H}), 7.14(\mathrm{q}, \mathrm{J}=8 \mathrm{~Hz}, 4 \mathrm{H})$, $6.87(\mathrm{~d}, \mathrm{~J}=12 \mathrm{~Hz}, 2 \mathrm{H}), 5.95(\mathrm{~s}, 1 \mathrm{H}), 3.83(\mathrm{~s}, 3 \mathrm{H}), 2.30$ (s, 3H).

${ }^{13} \mathrm{C}$ NMR $\left(100 \mathrm{MHz}, \mathrm{CDCl}_{3}\right) \delta 196.8,163.3,139.6,136.7,136.3,131.3,129.8,129.4,129.1,129.0$, 128.6, 126.9, 113.7, 58.7, 55.4, 21.0.

The spectra are in accordance with those of the compound reported in the literature 5 .<smiles>Cc1ccc(C(=O)C(c2ccccc2)c2ccc(C)cc2)cc1</smiles>

5b

The title compound was obtained in 76\% (45.6 mg) yield according to Procedure A, colorless oil. ${ }^{1} \mathrm{H}$ NMR $\left(400 \mathrm{MHz}, \mathrm{CDCl}_{3}\right) \delta 7.90(\mathrm{~d}, \mathrm{~J}=8 \mathrm{~Hz}, 2 \mathrm{H}), 7.32-7.10(\mathrm{~m}, 11 \mathrm{H}), 5.98(\mathrm{~s}, 1 \mathrm{H}), 2.36(\mathrm{~s}, 3 \mathrm{H})$, $2.30(\mathrm{~s}, 3 \mathrm{H})$.

${ }^{13} \mathrm{C}$ NMR $\left(100 \mathrm{MHz}, \mathrm{CDCl}_{3}\right) \delta 197.9,143.8,139.5,136.5,136.2,134.3,134.3,129.4,129.3,129.1$, 129.0, 128.6, 126.9, 58.9, 21.6, 21.0.

The spectra are in accordance with those of the compound reported in the literature ${ }^{5}$. 
<smiles>Cc1ccc(C(C(=O)c2ccc(F)cc2)c2ccccc2)cc1</smiles>

$5 \mathbf{c}$

The title compound was obtained in $75 \%$ (45.6 mg) yield according to Procedure A, white solid. ${ }^{1} \mathrm{H}$ NMR (400 MHz, $\left.\mathrm{CDCl}_{3}\right) \delta$ 8.05-7.96 (m, 2H), $7.32(\mathrm{t}, \mathrm{J}=8 \mathrm{~Hz}, 2 \mathrm{H}), 7.28-7.22(\mathrm{~m}, 3 \mathrm{H}), 7.18$ $7.10(\mathrm{~m}, 4 \mathrm{H}), 7.06(\mathrm{t}, \mathrm{J}=10 \mathrm{~Hz}, 2 \mathrm{H}), 5.94(\mathrm{~s}, 1 \mathrm{H}), 2.31(\mathrm{~s}, 3 \mathrm{H})$.

${ }^{13} \mathrm{C}$ NMR $\left(100 \mathrm{MHz}, \mathrm{CDCl}_{3}\right) \delta$ 196.7, $165.5(\mathrm{C}-\mathrm{F}, \mathrm{d}, \mathrm{J}=254 \mathrm{~Hz}), 139.1,136.9,135.8,133.1,131.6$ (C-F, d, J = $10 \mathrm{~Hz}), 129.5,129.0,128.9,128.7,127.1,115.7$ (C-F, d, J = $21 \mathrm{~Hz}), 59.1,21.0$.

${ }^{19} \mathrm{~F}$ NMR $\left(376 \mathrm{MHz}, \mathrm{CDCl}_{3}\right) \delta-105.18(\mathrm{~m}, 1 \mathrm{~F})$.

HRMS $(\mathrm{M}+\mathrm{H})^{+}$: Calcd for $\mathrm{C}_{21} \mathrm{H}_{18} \mathrm{FO}: 305.1336$, found 305.1341 .<smiles>Cc1ccc(C(C(=O)c2ccc(-c3ccccc3)cc2)c2ccccc2)cc1</smiles>

\section{5d}

The title compound was obtained in $91 \%(65.9 \mathrm{mg})$ yield according to Procedure A, white solid. ${ }^{1} \mathrm{H} \mathrm{NMR}\left(400 \mathrm{MHz}, \mathrm{CDCl}_{3}\right) \delta 8.09(\mathrm{~d}, \mathrm{~J}=8 \mathrm{~Hz}, 2 \mathrm{H}), 7.64-7.58(\mathrm{~m}, 4 \mathrm{H}), 7.46(\mathrm{t}, \mathrm{J}=8 \mathrm{~Hz}, 2 \mathrm{H}), 7.40$ (d, J $=8 \mathrm{~Hz}, 2 \mathrm{H}), 7.36-7.27$ (m, 5H), 7.21-7.14 (m, 4H), 6.05 (s, 1H), 2.33 (s, 3H).

${ }^{13} \mathrm{C}$ NMR $\left(100 \mathrm{MHz}, \mathrm{CDCl}_{3}\right) \delta 197.9,145.6,139.8,139.3,136.8,136.1,135.5,129.6,129.5,129.1$, 129.0, 128.9, 128.7, 128.2, 127.23, 127.21, 127.1, 59.1, 21.1.

HRMS $(\mathrm{M}+\mathrm{H})^{+}$: Calcd for $\mathrm{C}_{27} \mathrm{H}_{23} \mathrm{O}: 363.1743$, found 363.1742 .<smiles>COc1ccc(C(=O)C(c2ccccc2)c2ccc(C)cc2)cc1OC</smiles>

$5 e$

The title compound was obtained in $91 \%$ (63.2 mg) yield according to Procedure A, white solid. ${ }^{1} \mathrm{H}$ NMR (400 MHz, CDCl $) \delta 7.64(\mathrm{~d}, \mathrm{~J}=8 \mathrm{~Hz}, 1 \mathrm{H}), 7.58(\mathrm{~s}, 1 \mathrm{H}), 7.35-7.20(\mathrm{~m}, 5 \mathrm{H}), 7.15(\mathrm{q}, \mathrm{J}=$ $8 \mathrm{~Hz}, 4 \mathrm{H}), 6.82(\mathrm{~d}, \mathrm{~J}=8 \mathrm{~Hz}, 1 \mathrm{H}), 5.98(\mathrm{~s}, 1 \mathrm{H}), 3.90$ (s, 3H), 3.87 (s, 3H), 2.31 (s, 3H).

${ }^{13} \mathrm{C}$ NMR $\left(100 \mathrm{MHz}, \mathrm{CDCl}_{3}\right) \delta 197.0,153.1,148.9,139.6,136.7,136.3,129.8,129.4,129.0,128.9$, 128.6, 127.0, 123.6, 111.0, 109.9, 58.6, 56.0, 55.8, 21.0.

HRMS (M+Na) ${ }^{+}$: Calc'd for $\mathrm{C}_{23} \mathrm{H}_{22} \mathrm{O}_{3} \mathrm{Na}: 369.1461$, found 369.1462 . 
<smiles>Cc1ccc(C(C(=O)c2ccc3c(c2)OCCO3)c2ccccc2)cc1</smiles>

$\mathbf{5 f}$

The title compound was obtained in $93 \%$ (64.0 mg) yield according to Procedure A, white solid. ${ }^{1} \mathrm{H}$ NMR (400 MHz, $\left.\mathrm{CDCl}_{3}\right) \delta$ 7.56-7.52 (m,2H), 7.33-7.20 (m, 5H), 7.13(q, J = 8 Hz, 4H), $6.84(\mathrm{~d}$, $\mathrm{J}=8 \mathrm{~Hz}, 1 \mathrm{H}), 5.92(\mathrm{~s}, 1 \mathrm{H}), 2.30(\mathrm{~s}, 3 \mathrm{H}), 3.87$ (s, 3H), $2.31(\mathrm{~s}, 3 \mathrm{H})$.

${ }^{13} \mathrm{C}$ NMR $\left(100 \mathrm{MHz}, \mathrm{CDCl}_{3}\right) \delta 196.7,147.9,143.2,139.5,136.7,136.2,130.6,129.4,129.1,128.9$, 128.6, 126.9, 123.1, 118.5, 117.2, 64.6, 64.0, 58.7, 21.0.

HRMS $(\mathrm{M}+\mathrm{H})^{+}$: Calcd for $\mathrm{C}_{23} \mathrm{H}_{21} \mathrm{O}_{3}: 345.1485$, found 345.1485 .<smiles>Cc1ccc(C(C(=O)c2ccccc2)c2ccc(C)cc2)cc1</smiles>

\section{$5 g$}

The title compound was obtained in 74\% (44.4 mg) yield according to Procedure A, colorless oil. ${ }^{1} \mathrm{H}$ NMR (400 MHz, CDCl $) \delta 8.01(\mathrm{~d}, \mathrm{~J}=8 \mathrm{~Hz}, 2 \mathrm{H}), 7.51(\mathrm{t}, \mathrm{J}=8 \mathrm{~Hz}, 1 \mathrm{H}), 7.41(\mathrm{t}, \mathrm{J}=8 \mathrm{~Hz}, 2 \mathrm{H})$, 7.20-7.10 (m, 8H), $5.98(\mathrm{~s}, 1 \mathrm{H}), 2.32(\mathrm{~s}, 3 \mathrm{H})$.

${ }^{13} \mathrm{C}$ NMR $\left(100 \mathrm{MHz}, \mathrm{CDCl}_{3}\right) \delta 198.5,136.8,136.7,136.2,132.9,129.4,128.9,128.9,128.5,58.7$, 21.0.

The spectra are in accordance with those of the compound reported in the literature ${ }^{5}$.<smiles>Cc1ccc(C(C(=O)c2ccccc2)c2ccc(F)cc2)cc1</smiles>

\section{$\mathbf{5 h}$}

The title compound was obtained in 74\% (49.2 mg) yield according to Procedure A, colorless oil. ${ }^{1} \mathrm{H}$ NMR (400 MHz, CDCl $) \delta 8.01(\mathrm{~d}, \mathrm{~J}=8 \mathrm{~Hz}, 2 \mathrm{H}), 7.52(\mathrm{t}, \mathrm{J}=8 \mathrm{~Hz}, 1 \mathrm{H}), 7.41(\mathrm{t}, \mathrm{J}=8 \mathrm{~Hz}, 2 \mathrm{H})$, 7.24-7.20 (m, 2H), 7.17-7.12 (m, 4H), $7.00(\mathrm{t}, \mathrm{J}=8 \mathrm{~Hz}, 2 \mathrm{H}), 5.98(\mathrm{~s}, 1 \mathrm{H}), 2.31(\mathrm{~s}, 3 \mathrm{H})$.

${ }^{13} \mathrm{C}$ NMR $\left(100 \mathrm{MHz}, \mathrm{CDCl}_{3}\right) \delta$ 198.2, $161.9(\mathrm{C}-\mathrm{F}, \mathrm{d}, \mathrm{J}=244 \mathrm{~Hz}), 137.0,136.6,135.8,135.1(\mathrm{C}-\mathrm{F}$, $\mathrm{d}, \mathrm{J}=3 \mathrm{~Hz}), 133.1,130.6(\mathrm{C}-\mathrm{F}, \mathrm{d}, \mathrm{J}=8 \mathrm{~Hz}), 129.6,128.9,128.8,128.6,115.4(\mathrm{C}-\mathrm{F}, \mathrm{d}, \mathrm{J}=21 \mathrm{~Hz})$, 58.2, 21.0 .

${ }^{19} \mathrm{~F}$ NMR $\left(376 \mathrm{MHz}, \mathrm{CDCl}_{3}\right) \delta-115.83(\mathrm{~m}, 1 \mathrm{~F})$.

The spectra are in accordance with those of the compound reported in the literature 5 . 
<smiles>Cc1ccc(C(C)C(=O)c2ccccc2)cc1</smiles>

\section{$5 \mathbf{i}$}

The title compound was obtained in $82 \%$ (36.8 mg) yield according to Procedure B, colorless oil. ${ }^{1} \mathrm{H} \mathrm{NMR}\left(400 \mathrm{MHz}, \mathrm{CDCl}_{3}\right) \delta 7.95(\mathrm{~d}, \mathrm{~J}=8 \mathrm{~Hz}, 2 \mathrm{H}), 7.47(\mathrm{t}, \mathrm{J}=8 \mathrm{~Hz}, 1 \mathrm{H}), 7.37$ (t, J = 6 Hz, 2H), $7.17(\mathrm{~d}, \mathrm{~J}=8 \mathrm{~Hz}, 2 \mathrm{H}), 7.10(\mathrm{~d}, \mathrm{~J}=8 \mathrm{~Hz}, 2 \mathrm{H}), 4.65(\mathrm{q}, \mathrm{J}=10 \mathrm{~Hz}, 1 \mathrm{H}), 2.28(\mathrm{~s}, 1 \mathrm{H}), 1.50(\mathrm{~d}, \mathrm{~J}=8$ $\mathrm{Hz}, 3 \mathrm{H})$.

${ }^{13} \mathrm{C}$ NMR $\left(100 \mathrm{MHz}, \mathrm{CDCl}_{3}\right) \delta 200.4,138.4,136.5,132.7,129.6,128.7,128.4,127.6,47.4,21.0$, 19.5.

The spectra are in accordance with those of the compound reported in the literature 5 .<smiles>CCC(C(=O)c1ccccc1)c1ccc(C)cc1</smiles>

\section{$\mathbf{5 j}$}

The title compound was obtained in 73\% (34.8 mg) yield according to Procedure B, colorless oil. ${ }^{1} \mathrm{H}$ NMR $\left(400 \mathrm{MHz}, \mathrm{CDCl}_{3}\right) \delta 7.97(\mathrm{~d}, \mathrm{~J}=8 \mathrm{~Hz}, 2 \mathrm{H}), 7.47(\mathrm{t}, \mathrm{J}=6 \mathrm{~Hz}, 1 \mathrm{H}), 7.38(\mathrm{t}, \mathrm{J}=6 \mathrm{~Hz}, 2 \mathrm{H})$, $7.20(\mathrm{~d}, \mathrm{~J}=8 \mathrm{~Hz}, 2 \mathrm{H}), 7.10(\mathrm{~d}, \mathrm{~J}=8 \mathrm{~Hz}, 2 \mathrm{H}), 4.42(\mathrm{t}, \mathrm{J}=8 \mathrm{~Hz}, 1 \mathrm{H}), 2.28(\mathrm{~s}, 1 \mathrm{H}), 2.24-2.16(\mathrm{~m}$, $1 \mathrm{H}), 1.89-1.80(\mathrm{~m}, 1 \mathrm{H}), 0.91(\mathrm{t}, \mathrm{J}=6 \mathrm{~Hz}, 3 \mathrm{H})$.

${ }^{13} \mathrm{C}$ NMR $\left(100 \mathrm{MHz}, \mathrm{CDCl}_{3}\right) \delta 200.2,137.0,136.5,136.5,132.7,129.5,128.6,128.4,128.1,55.0$, 27.0, 21.0, 12.3 .

The spectra are in accordance with those of the compound reported in the literature 5 .<smiles>Cc1ccc(C(C(=O)c2ccccc2)C(C)C)cc1</smiles>

\section{$5 \mathbf{k}$}

The title compound was obtained in $68 \%$ (34.3 $\mathrm{mg}$ ) yield according to Procedure B, colorless oil. ${ }^{1} \mathrm{H}$ NMR $\left(400 \mathrm{MHz}, \mathrm{CDCl}_{3}\right) \delta 7.97(\mathrm{~d}, \mathrm{~J}=8 \mathrm{~Hz}, 2 \mathrm{H}), 7.48(\mathrm{t}, \mathrm{J}=6 \mathrm{~Hz}, 1 \mathrm{H}), 7.39(\mathrm{t}, \mathrm{J}=6 \mathrm{~Hz}, 2 \mathrm{H})$, $7.20(\mathrm{~d}, \mathrm{~J}=8 \mathrm{~Hz}, 2 \mathrm{H}), 7.10(\mathrm{~d}, \mathrm{~J}=8 \mathrm{~Hz}, 2 \mathrm{H}), 4.53(\mathrm{t}, \mathrm{J}=8 \mathrm{~Hz}, 1 \mathrm{H}), 2.28(\mathrm{~s}, 1 \mathrm{H}), 2.20-2.08(\mathrm{~m}$, $1 \mathrm{H}), 1.86-1.75(\mathrm{~m}, 1 \mathrm{H}), 1.36-1.22(\mathrm{~m}, 2 \mathrm{H}), 0.92(\mathrm{t}, \mathrm{J}=8 \mathrm{~Hz}, 3 \mathrm{H})$.

${ }^{13} \mathrm{C}$ NMR $\left(100 \mathrm{MHz}, \mathrm{CDCl}_{3}\right) \delta 200.2,136.9,136.7,136.5,132.7,129.5,128.6,128.4,128.0,52.9$, $36.1,21.0,20.8,14.1$.

The spectra are in accordance with those of the compound reported in the literature 5 .<smiles>Cc1ccc(C(Br)C(=O)c2ccccc2)cc1</smiles>

$5 \mathbf{l}$ 
The title compound was obtained in $37 \%$ (22.4 mg) yield according to Procedure B, white solid. ${ }^{1} \mathrm{H}$ NMR (400 MHz, CDCl $) \delta 7.89(\mathrm{~d}, \mathrm{~J}=8 \mathrm{~Hz}, 2 \mathrm{H}), 7.44(\mathrm{t}, \mathrm{J}=8 \mathrm{~Hz}, 1 \mathrm{H}), 7.34(\mathrm{t}, \mathrm{J}=8 \mathrm{~Hz}, 2 \mathrm{H})$, $7.20(\mathrm{t}, \mathrm{J}=8 \mathrm{~Hz}, 2 \mathrm{H}), 7.17-7.04(\mathrm{~m}, 7 \mathrm{H}), 4.78(\mathrm{t}, \mathrm{J}=8 \mathrm{~Hz}, 1 \mathrm{H}), 3.55(\mathrm{q}, \mathrm{J}=6 \mathrm{~Hz}, 1 \mathrm{H}), 3.04(\mathrm{q}, \mathrm{J}=$ $6 \mathrm{~Hz}, 1 \mathrm{H}), 2.27(\mathrm{~s}, 3 \mathrm{H})$.

${ }^{13} \mathrm{C}$ NMR $\left(100 \mathrm{MHz}, \mathrm{CDCl}_{3}\right) \delta 199.3,139.9,136.8,136.7,136.0,132.8,129.6,129.1,128.7,128.4$, 128.2, 128.1, 126.0, 55.4, 40.1, 21.0 .

HRMS (M) ${ }^{+}$: Calcd for $\mathrm{C}_{22} \mathrm{H}_{20} \mathrm{O}: 300.1509$, found 300.1507 .<smiles>O=C(c1ccccc1)C1CCOc2ccccc21</smiles>

\section{8}

The title compound was obtained in $51 \%(24.1 \mathrm{mg})$ yield, white solid.

${ }^{1} \mathrm{H}$ NMR $\left(400 \mathrm{MHz}, \mathrm{CDCl}_{3}\right) \delta 8.02(\mathrm{~d}, \mathrm{~J}=8 \mathrm{~Hz}, 2 \mathrm{H}), 7.62(\mathrm{t}, \mathrm{J}=6 \mathrm{~Hz}, 1 \mathrm{H}), 7.51(\mathrm{t}, \mathrm{J}=6 \mathrm{~Hz}, 2 \mathrm{H})$, $7.16(\mathrm{t}, \mathrm{J}=8 \mathrm{~Hz}, 1 \mathrm{H}), 6.90(\mathrm{~d}, \mathrm{~J}=8 \mathrm{~Hz}, 2 \mathrm{H}), 6.82(\mathrm{t}, \mathrm{J}=6 \mathrm{~Hz}, 1 \mathrm{H}), 4.83(\mathrm{t}, \mathrm{J}=6 \mathrm{~Hz}, 1 \mathrm{H}), 4.33-$ $4.20(\mathrm{~m}, 2 \mathrm{H}), 2.37-2.22(\mathrm{~m}, 2 \mathrm{H})$.

${ }^{13} \mathrm{C}$ NMR $\left(100 \mathrm{MHz}, \mathrm{CDCl}_{3}\right) \delta 201.0,155.1,136.2,133.4,129.6,129.8,128.9,128.8,128.4,120.5$, 119.9, 117.3, 63.4, 42.3, 26.1.

The spectra are in accordance with those of the compound reported in the literature ${ }^{5}$.<smiles>O=C(c1ccccc1)C(c1ccccc1)c1ccc(Oc2ccccc2)cc1</smiles>

10

The title compound was obtained in $71 \%(51.5 \mathrm{mg})$ yield, yellow oil. ${ }^{1} \mathrm{H}$ NMR $\left(400 \mathrm{MHz}, \mathrm{CDCl}_{3}\right) \delta 8.00(\mathrm{~d}, \mathrm{~J}=8 \mathrm{~Hz}, 2 \mathrm{H}), 7.51(\mathrm{t}, \mathrm{J}=6 \mathrm{~Hz}, 1 \mathrm{H}), 7.40(\mathrm{t}, \mathrm{J}=8 \mathrm{~Hz}, 2 \mathrm{H})$, 7.34-7.21 (m, 9H), $6.08(\mathrm{t}, \mathrm{J}=8 \mathrm{~Hz}, 1 \mathrm{H}), 7.00-6.93(\mathrm{~m}, 4 \mathrm{H}), 6.01(\mathrm{~s}, 1 \mathrm{H})$. ${ }^{13} \mathrm{C}$ NMR $\left(100 \mathrm{MHz}, \mathrm{CDCl}_{3}\right) \delta 198.2,156.9,156.4,139.1,136.8,133.8,133.1,130.4,129.7,129.0$, 128.9, 128.8, 128.6, 127.2, 123.4, 119.1, 118.7, 58.6.

HRMS $(\mathrm{M}+\mathrm{H})^{+}$: Calcd for $\mathrm{C}_{26} \mathrm{H}_{21} \mathrm{O}_{2}: 365.1536$, found 365.1523 .<smiles>COc1ccc(-c2ccc(C(C(=O)c3ccccc3)c3ccccc3)cc2C)cc1</smiles>

14

The title compound was obtained in $78 \%(61.3 \mathrm{mg})$ yield, colorless oil. 
${ }^{1} \mathrm{H}$ NMR (400 MHz, CDCl $) \delta 8.04(\mathrm{~d}, \mathrm{~J}=8 \mathrm{~Hz}, 2 \mathrm{H}), 7.53(\mathrm{t}, \mathrm{J}=6 \mathrm{~Hz}, 1 \mathrm{H}), 7.43(\mathrm{t}, \mathrm{J}=8 \mathrm{~Hz}, 2 \mathrm{H})$, 7.37-7.34 (m, 4H), 7.29-7.21 (m, 3H), 7.18-7.10 (m, 3H), 6.93 (d, J = 8 Hz, 2H), 6.04 (s, 1H), 3.83 (s, 3H), 2.23 (s, 3H).

${ }^{13} \mathrm{C}$ NMR (100 MHz, $\left.\mathrm{CDCl}_{3}\right) \delta 198.3,158.4,140.3,139.1,137.5,136.8,135.8,133.9,133.0,130.9$, 130.23, 130.21, 129.1, 129.0, 128.7, 128.6, 127.1, 126.5, 113.4, 59.1, 55.2, 20.7.

HRMS $(\mathrm{M}+\mathrm{H})^{+}$: Calcd for $\mathrm{C}_{28} \mathrm{H}_{25} \mathrm{O}_{2}: 393.1849$, found 393.1840. 


\section{References}

1. Chang, F.; Lin, L.; Xia, Y.; Zhang, H.; Dong, S.; Liu, X.; Feng, X., Chiral N,N'-Dioxide/Sc ${ }^{\mathrm{III}}$ Complex-Catalyzed Asymmetric Ring-Opening Reaction of Cyclopropyl Ketones with Indoles. $A d v$. Synth. Catal. 2018, 360, 2608.

2. Ma, P.; Wang, S.; Chen, H., Reactivity of Transition-Metal Complexes in Excited States: CO Bond Coupling Reductive Elimination of a Ni(II) Complex Is Elicited by the Metal-to-Ligand Charge Transfer State. ACS Catal. 2019, 10, 1.

3. Toth, P. M.; Lieber, S.; Scheer, F. M.; Schumann, T.; Schober, Y.; Nockher, W. A.; Adhikary, T.; Muller-Brusselbach, S.; Muller, R.; Diederich, W. E., Design and Synthesis of Highly Active Peroxisome Proliferator-Activated Receptor (PPAR) beta/delta Inverse Agonists with Prolonged Cellular Activity. ChemMedChem. 2016, 11, 488.

4. Yamada, A.; Fujii, S.; Mori, S.; Kagechika, H., Design and Synthesis of 4-(4Benzoylaminophenoxy)phenol Derivatives As Androgen Receptor Antagonists. ACS Medicinal Chem. Lett. 2013, 4, 937.

5. Danoun, G.; Tlili, A.; Monnier, F.; Taillefer, M., Direct copper-catalyzed alpha-arylation of benzyl phenyl ketones with aryl iodides: route towards tamoxifen. Angew. Chem. Int. Ed. 2012, 51, 12815 . 
${ }^{1} \mathbf{H}$ NMR spectrum of $\mathbf{3 a}$ in $\mathrm{CDCl}_{3}(400 \mathrm{MHz})$
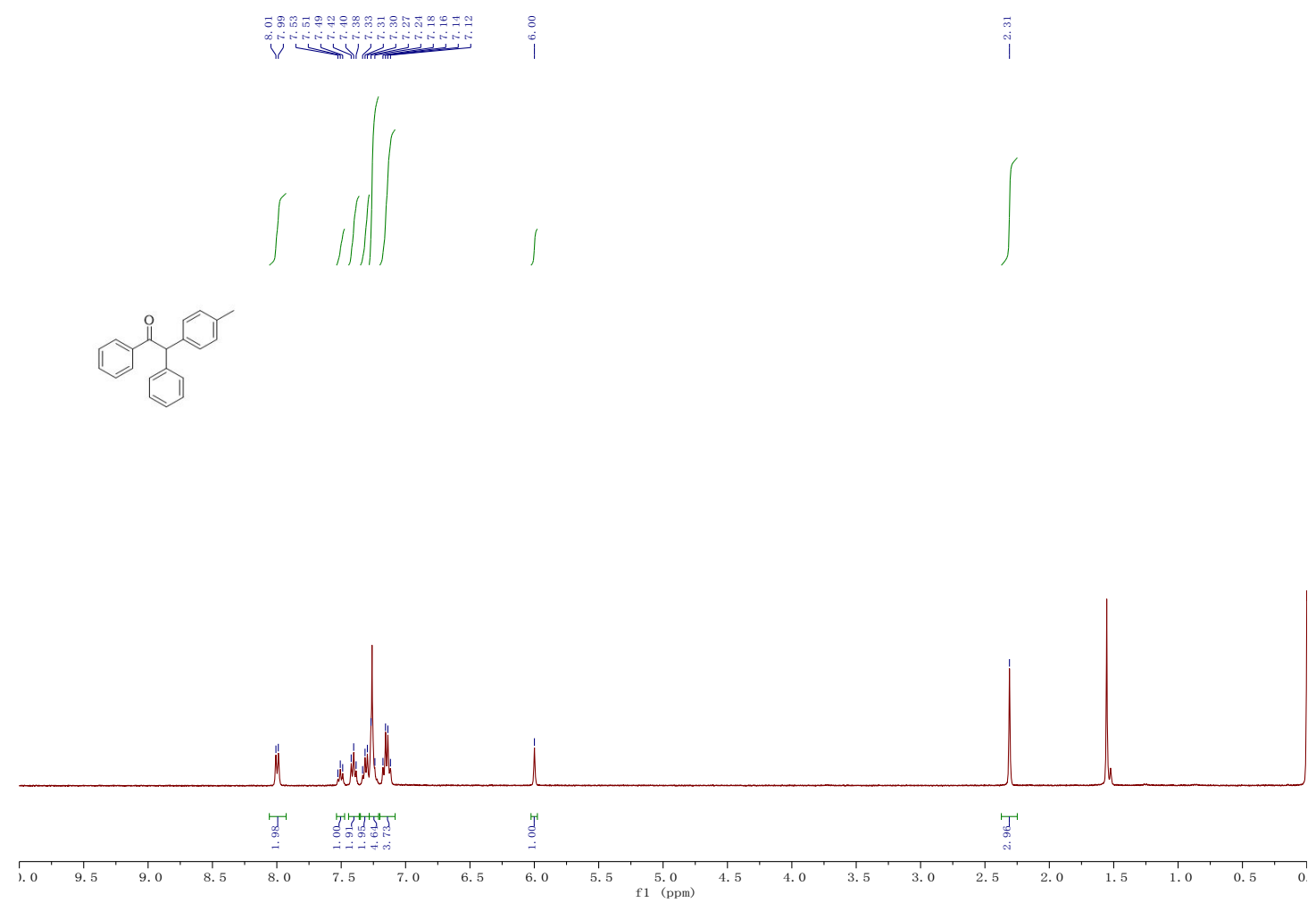

${ }^{13} \mathbf{C}$ NMR spectrum of $\mathbf{3 a}$ in $\mathrm{CDCl}_{3}(100 \mathrm{MHz})$

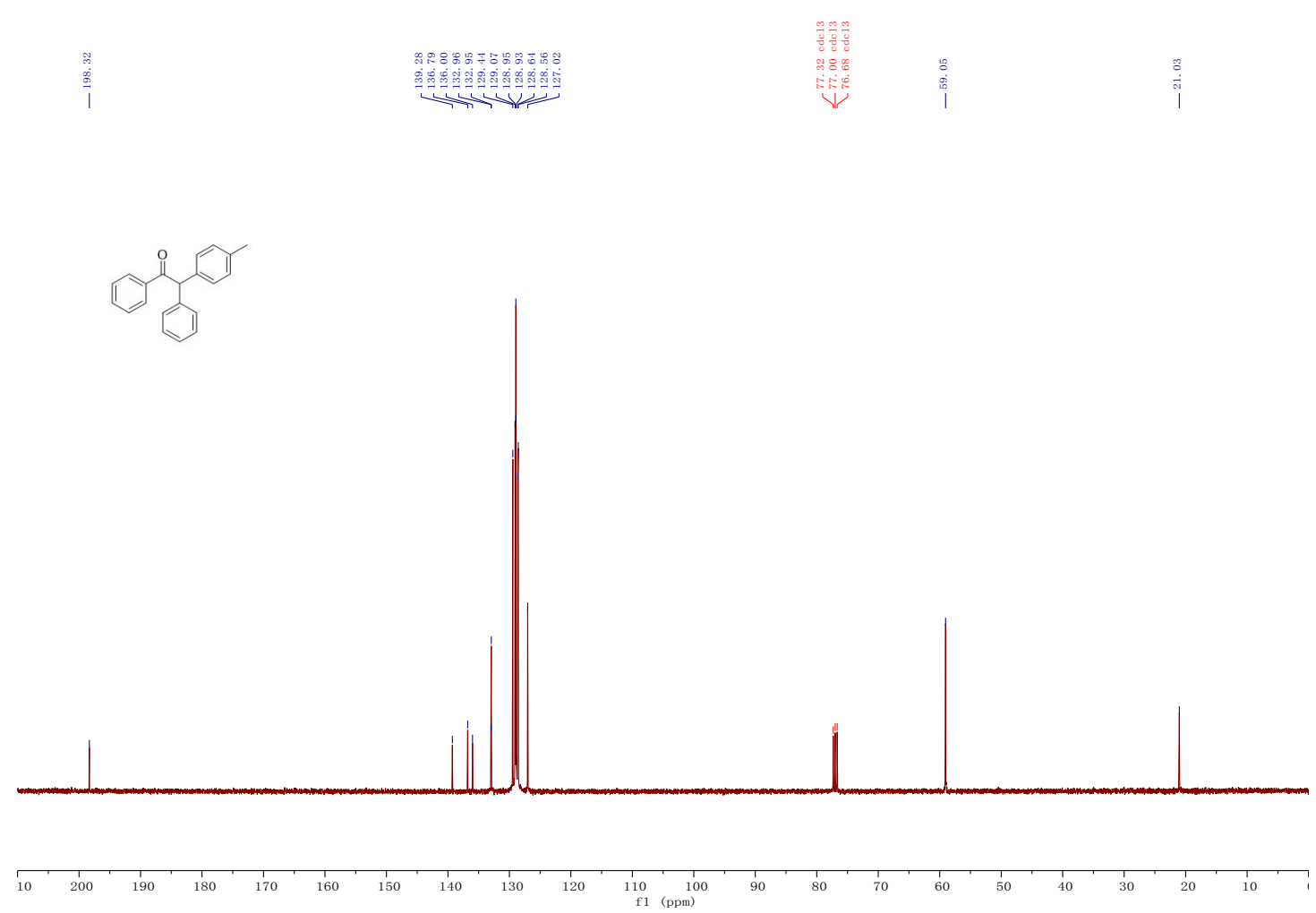


${ }^{1} \mathbf{H}$ NMR spectrum of $\mathbf{3 b}$ in $\mathrm{CDCl}_{3}(400 \mathrm{MHz})$
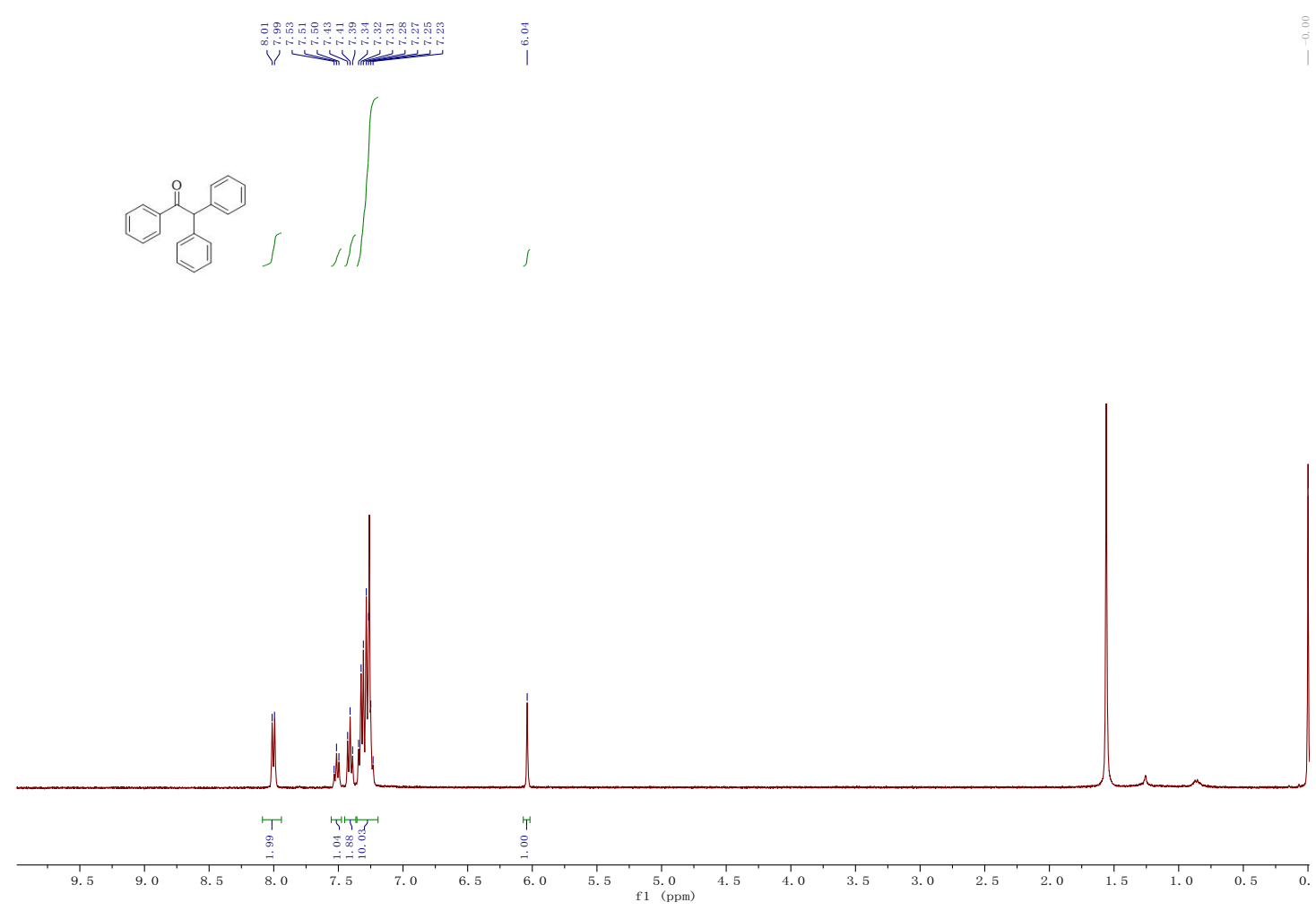

${ }^{13} \mathbf{C}$ NMR spectrum of $\mathbf{3 b}$ in $\mathrm{CDCl}_{3}(100 \mathrm{MHz})$
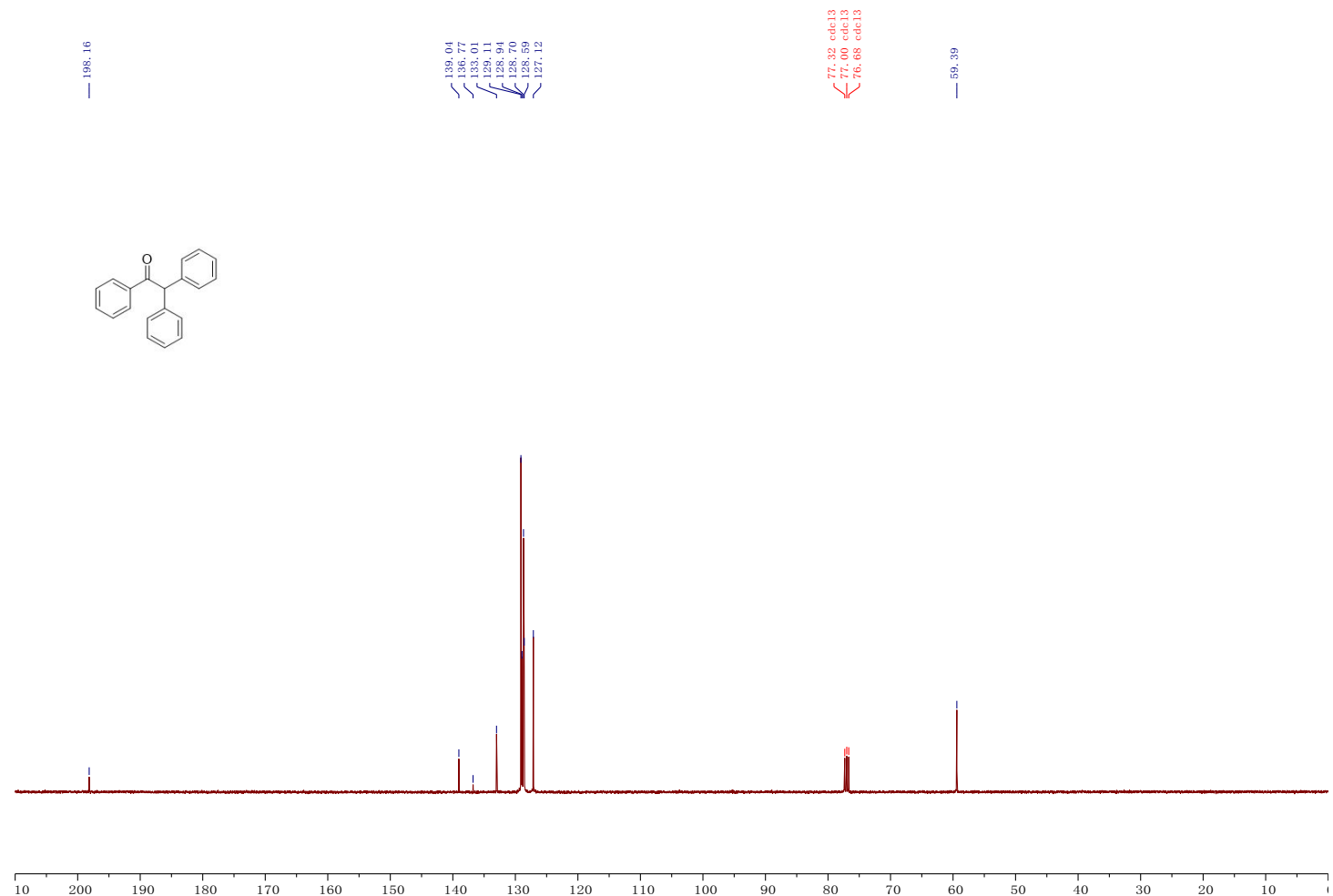

$\begin{array}{ll}110 & 100 \\ \mathrm{f} 1 & (\mathrm{ppm})\end{array}$ 
${ }^{1} \mathbf{H}$ NMR spectrum of $\mathbf{3 c}$ in $\mathrm{CDCl}_{3}(400 \mathrm{MHz})$
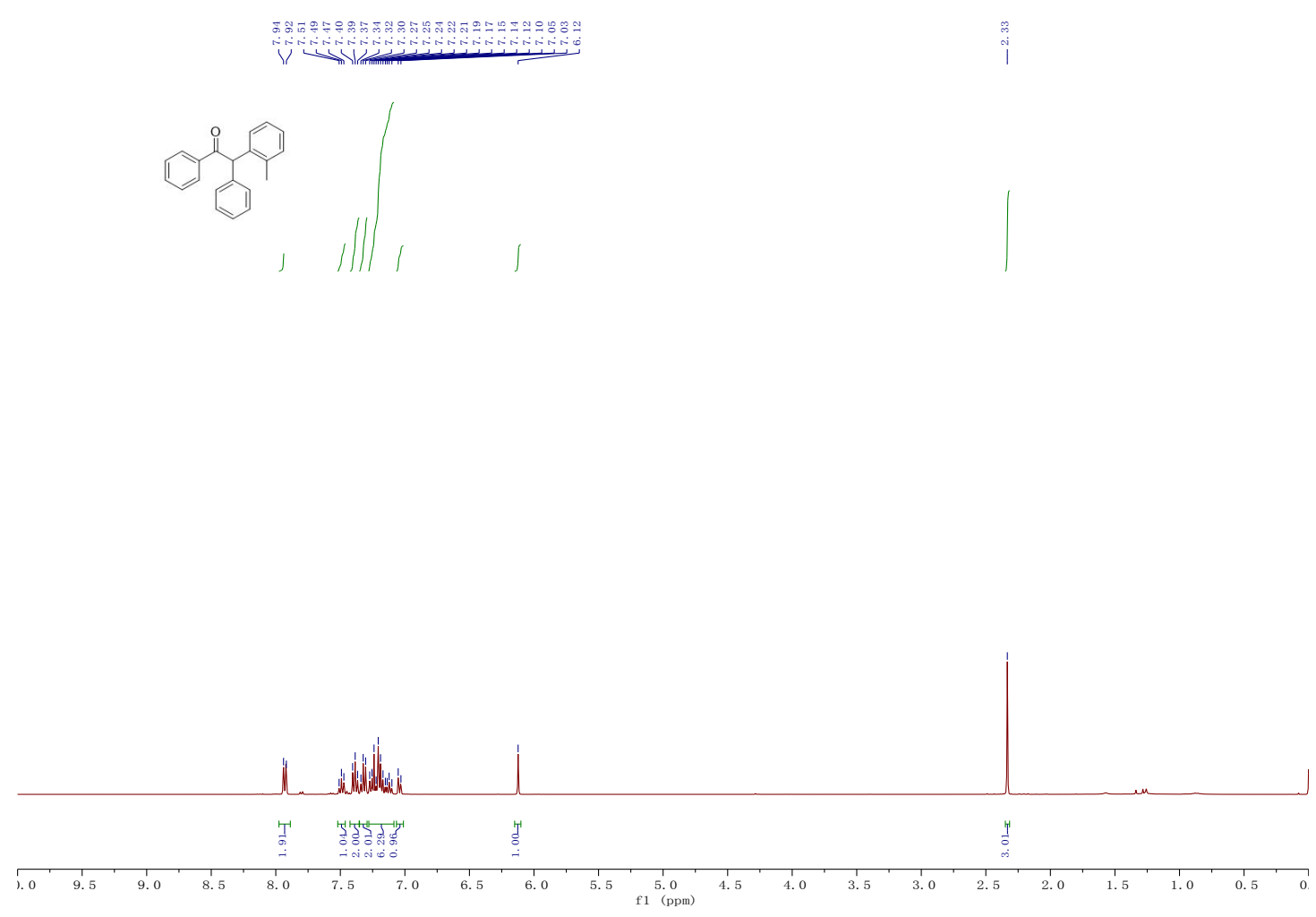

${ }^{13} \mathbf{C}$ NMR spectrum of $\mathbf{3 c}$ in $\mathrm{CDCl}_{3}(100 \mathrm{MHz})$
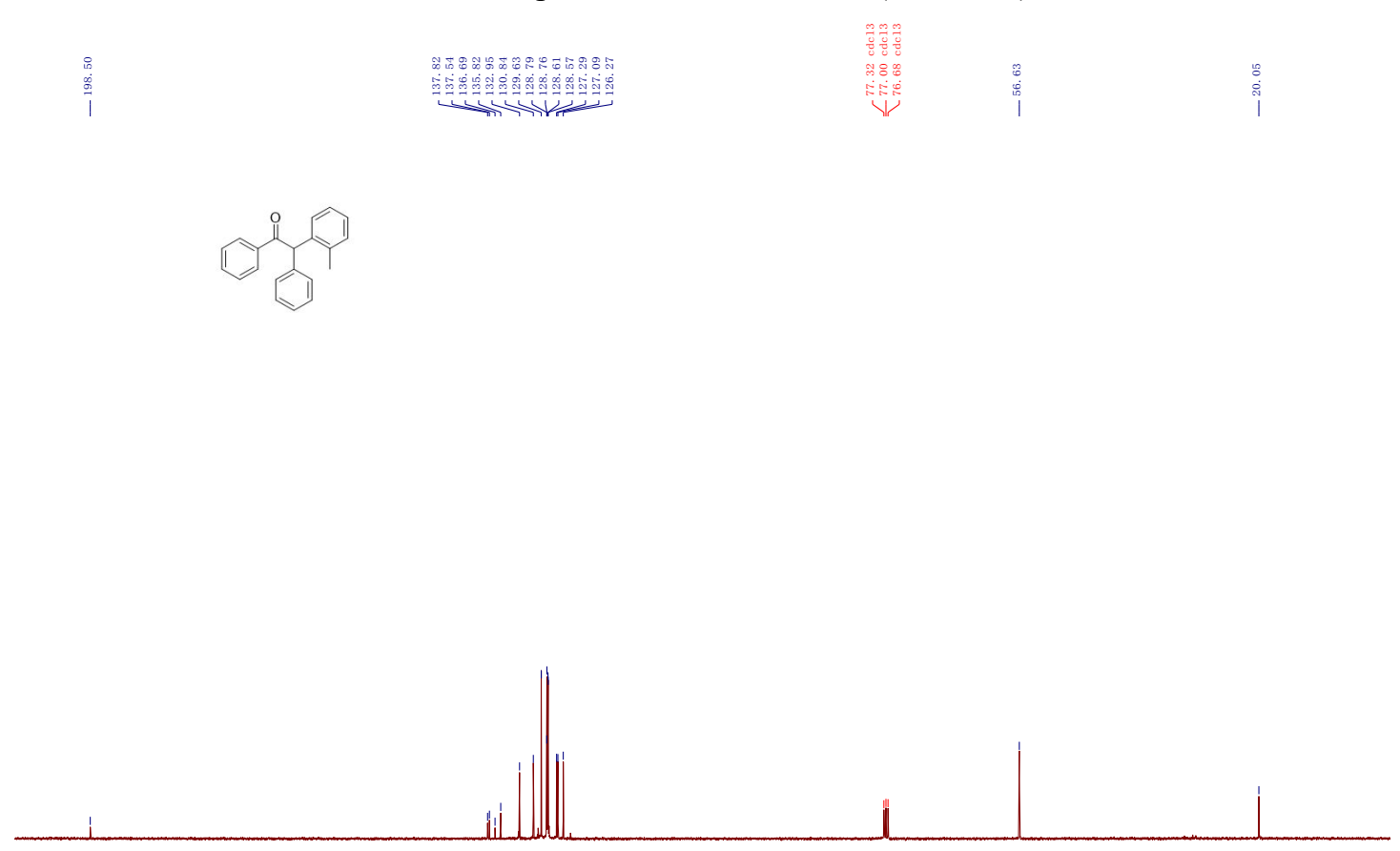

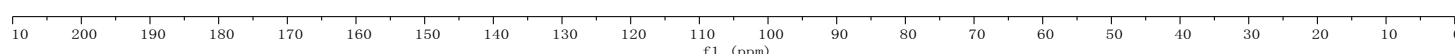


${ }^{1} \mathbf{H}$ NMR spectrum of $\mathbf{3 d}$ in $\mathrm{CDCl}_{3}(400 \mathrm{MHz})$
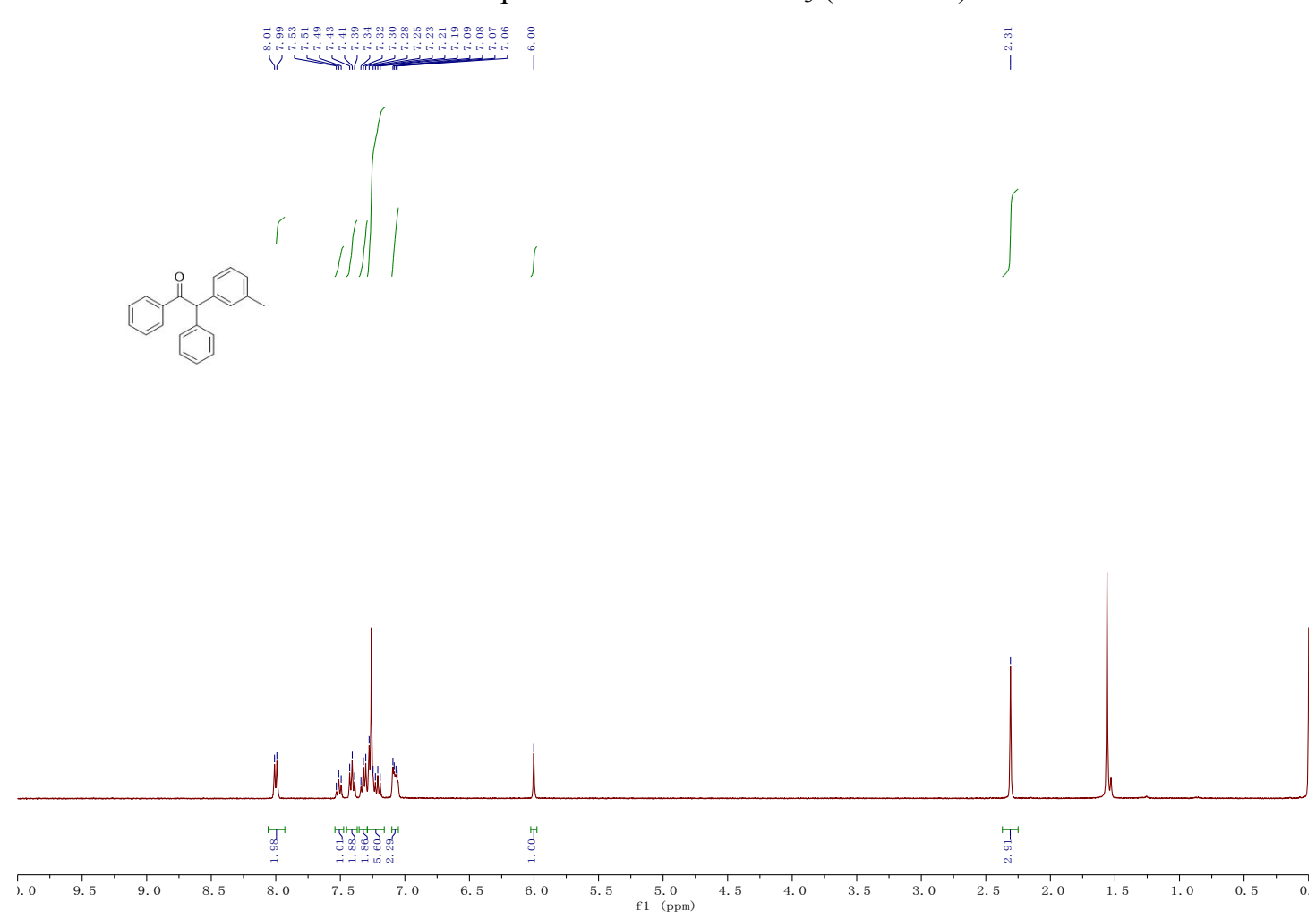

${ }^{13} \mathbf{C}$ NMR spectrum of $\mathbf{3 d}$ in $\mathrm{CDCl}_{3}(100 \mathrm{MHz})$
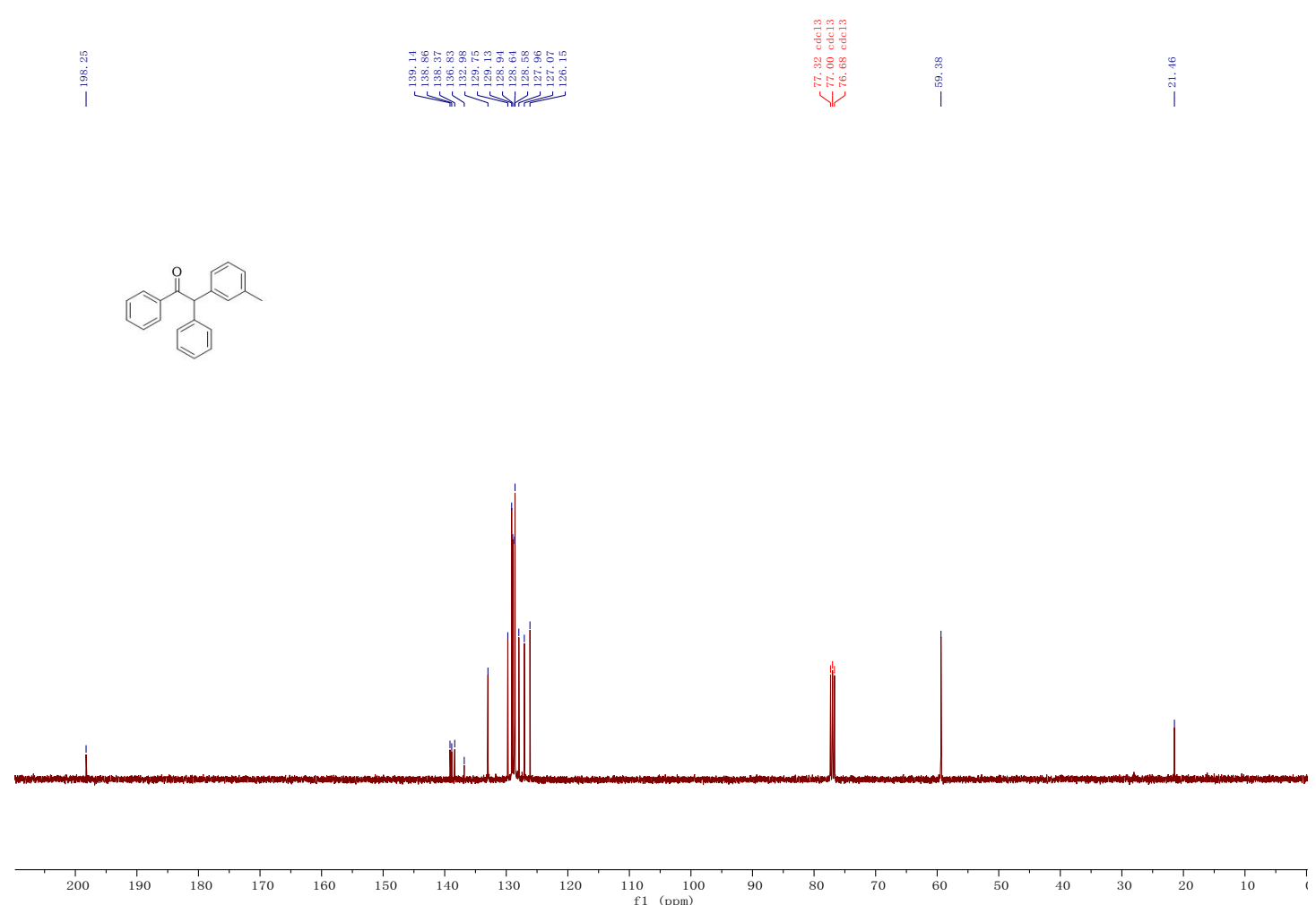
${ }^{1} \mathbf{H}$ NMR spectrum of $\mathbf{3 e}$ in $\mathrm{CDCl}_{3}(400 \mathrm{MHz})$
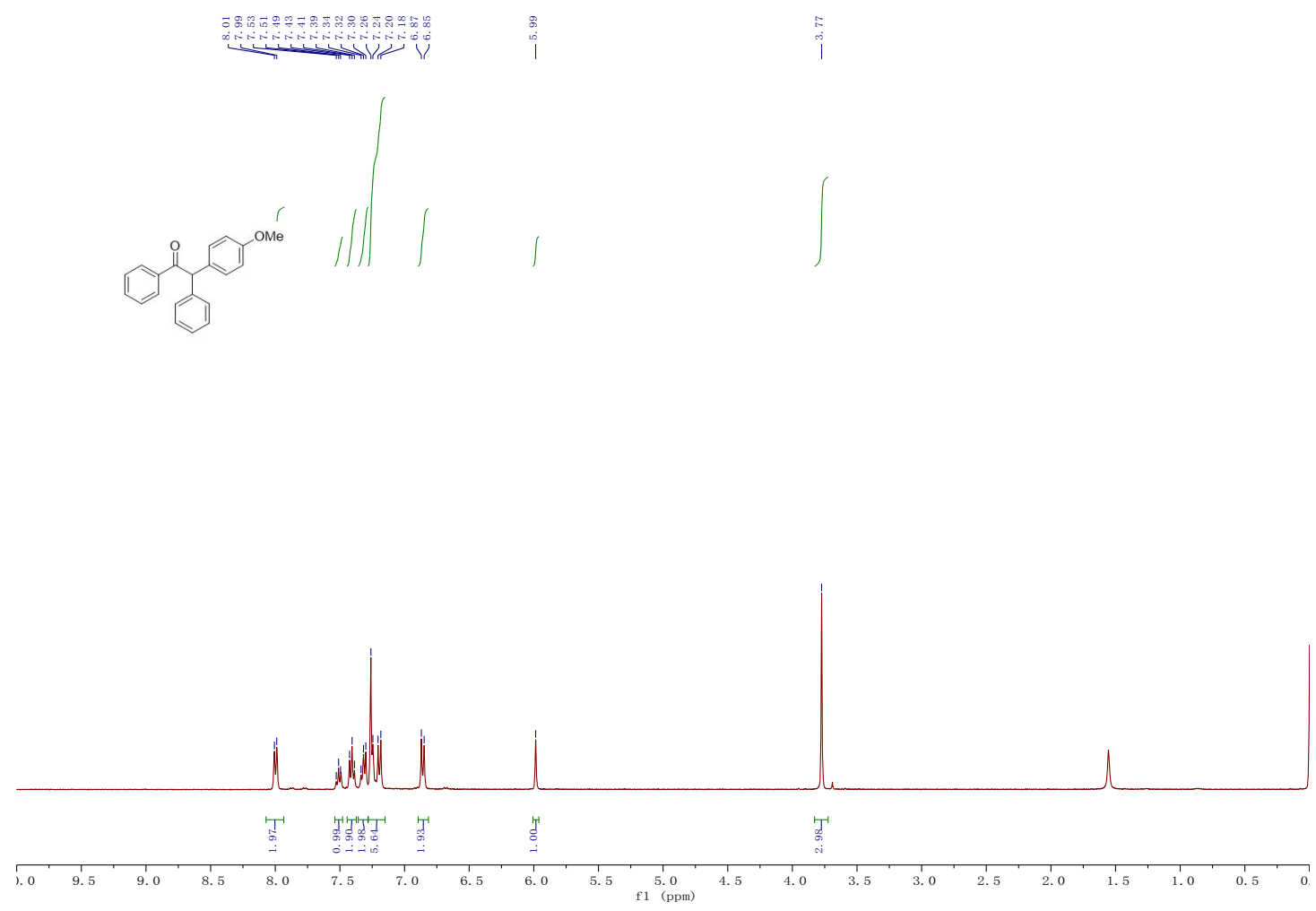

${ }^{13} \mathbf{C}$ NMR spectrum of $\mathbf{3 e}$ in $\mathrm{CDCl}_{3}(100 \mathrm{MHz})$
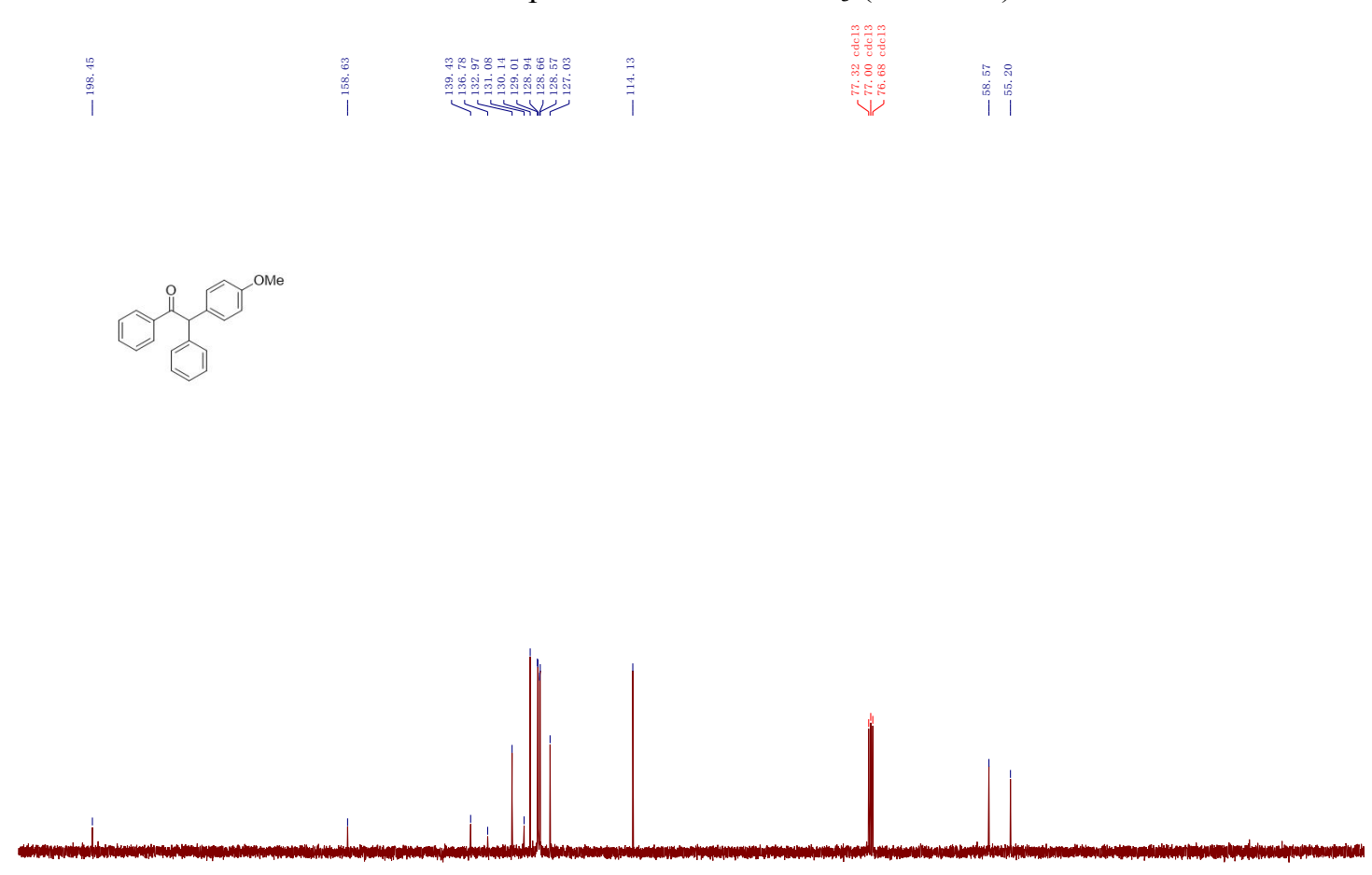

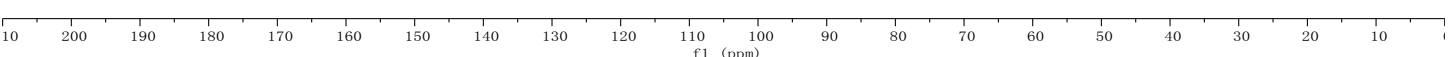


${ }^{\mathbf{1}} \mathbf{H}$ NMR spectrum of $\mathbf{3 f}$ in $\mathrm{CDCl}_{3}(400 \mathrm{MHz})$
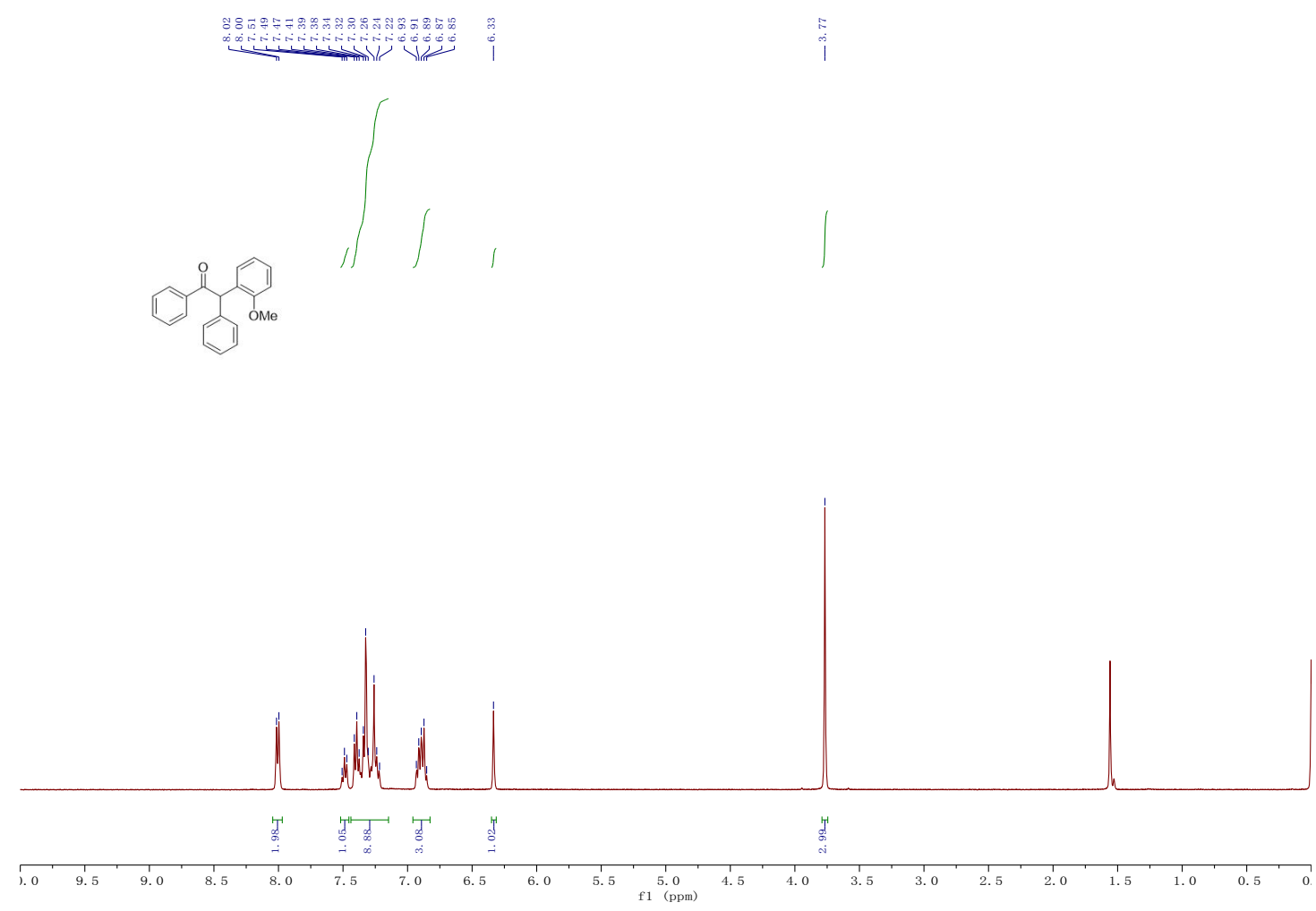

${ }^{13} \mathbf{C}$ NMR spectrum of $\mathbf{3} \mathbf{f}$ in $\mathrm{CDCl}_{3}(100 \mathrm{MHz})$
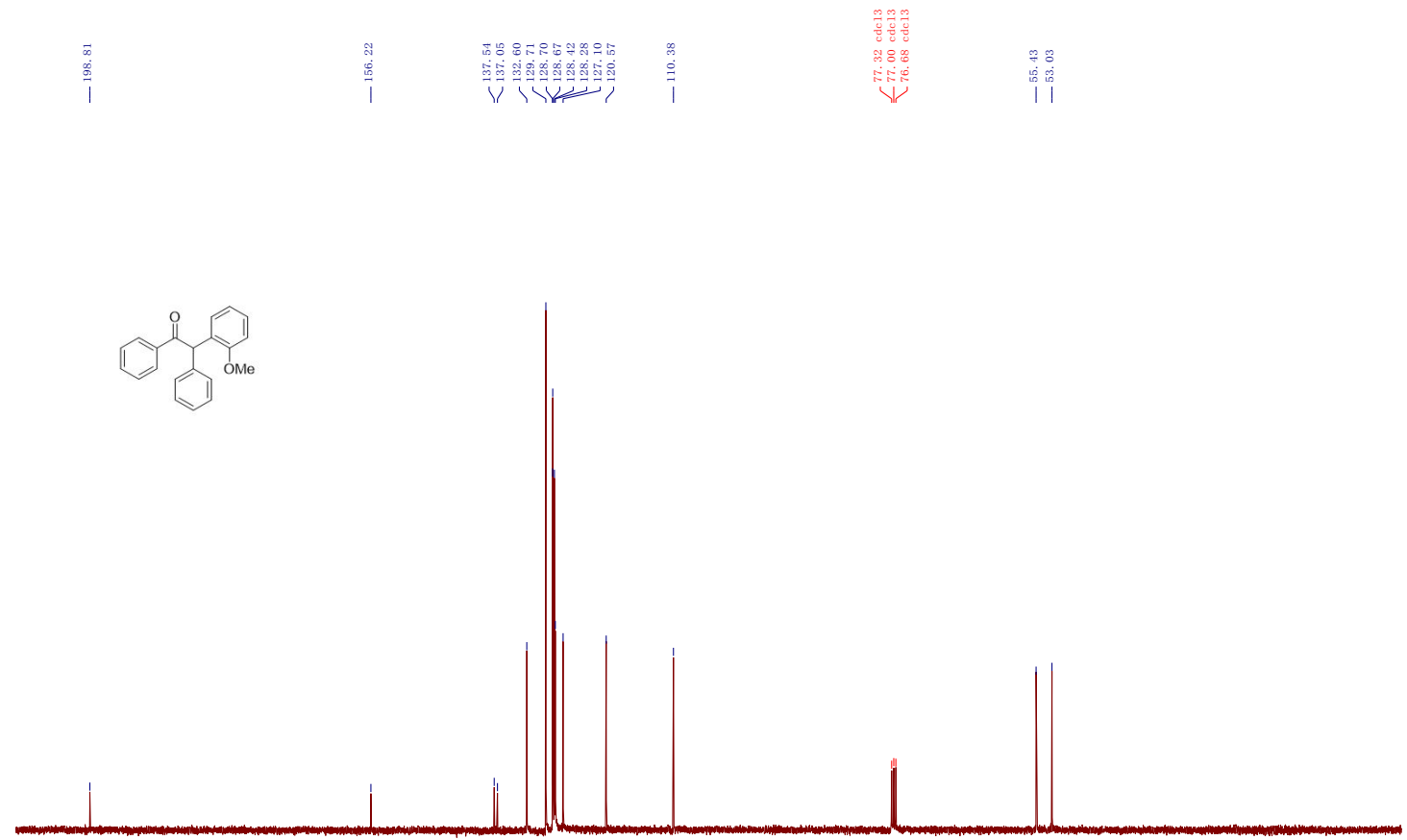
${ }^{1} \mathbf{H}$ NMR spectrum of $\mathbf{3 g}$ in $\mathrm{CDCl}_{3}(400 \mathrm{MHz})$

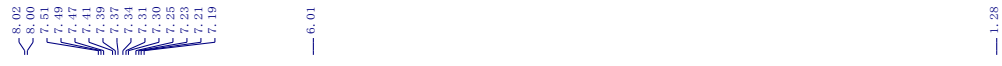
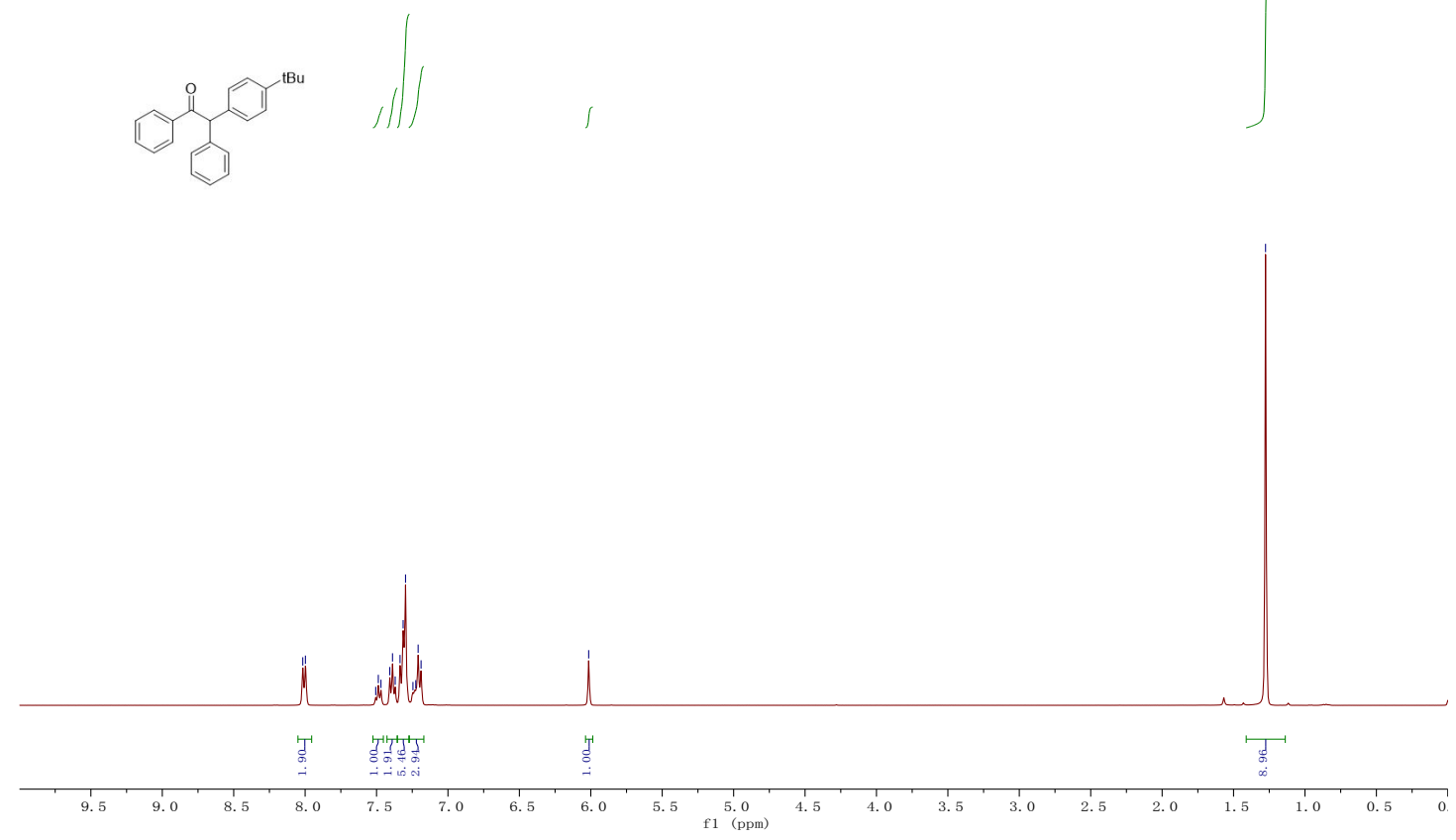

${ }^{13} \mathbf{C}$ NMR spectrum of $\mathbf{3 g}$ in $\mathrm{CDCl}_{3}(100 \mathrm{MHz})$

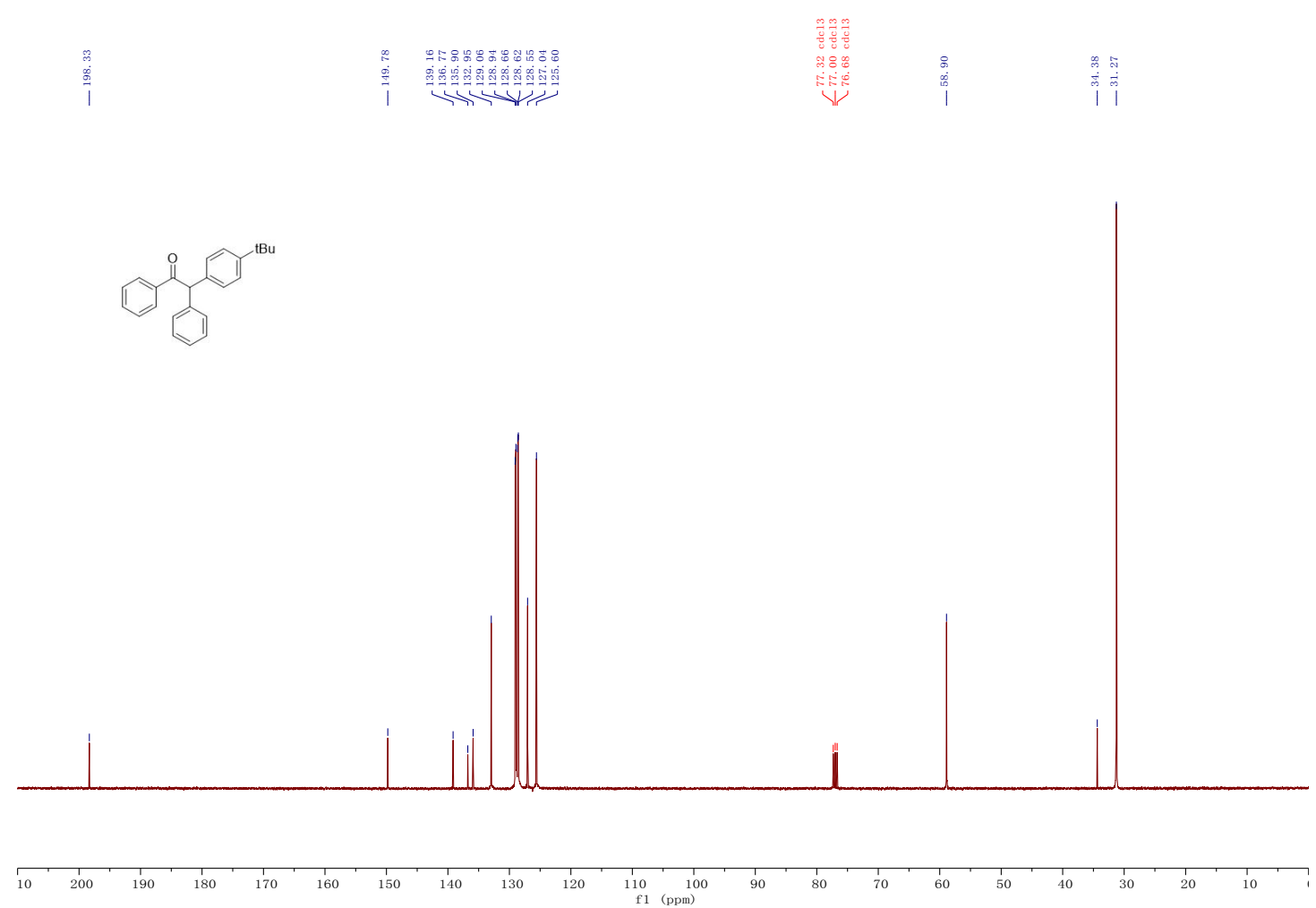


${ }^{\mathbf{1}} \mathbf{H}$ NMR spectrum of $\mathbf{3 h}$ in $\mathrm{CDCl}_{3}(400 \mathrm{MHz})$

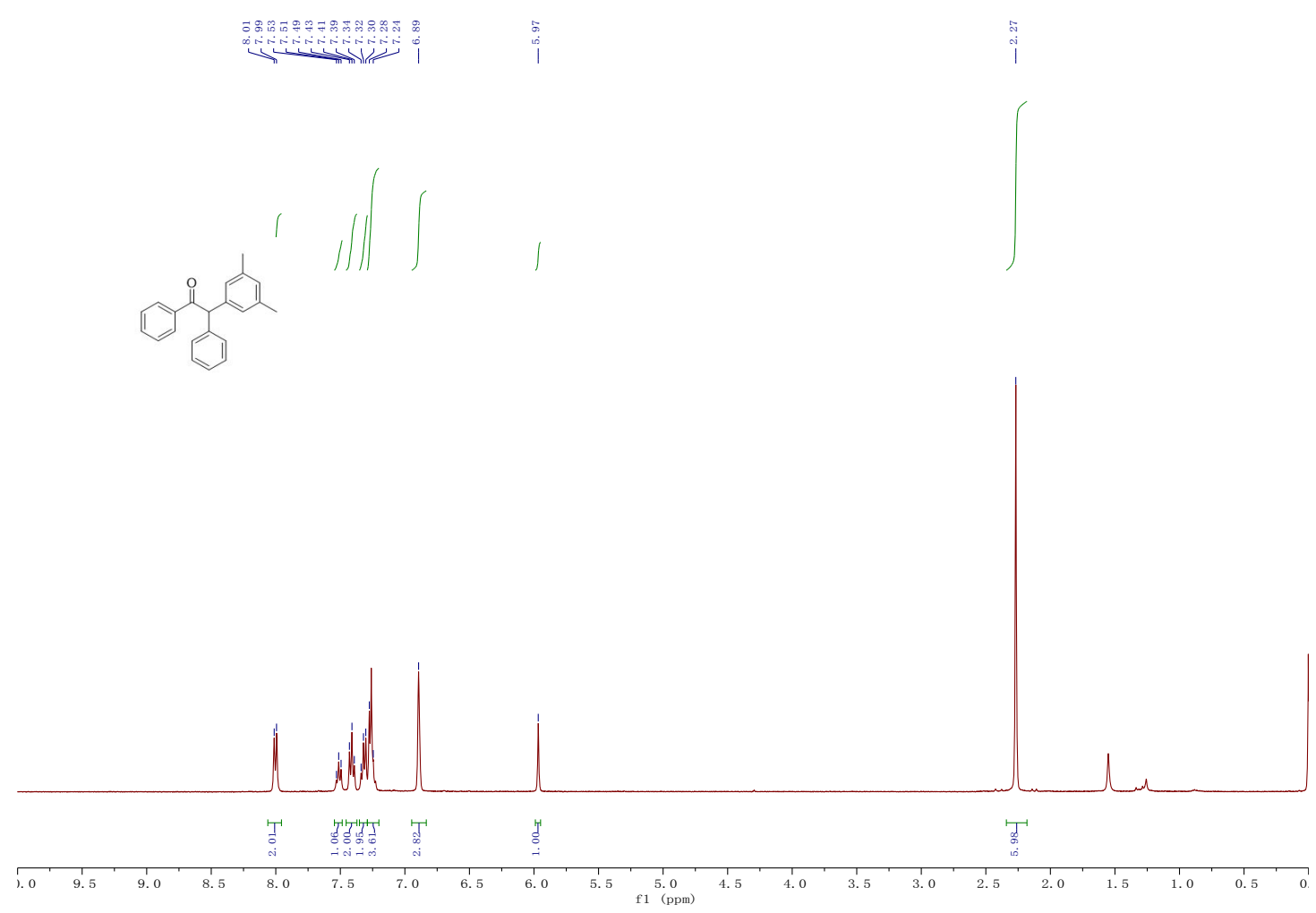

${ }^{13} \mathbf{C}$ NMR spectrum of $\mathbf{3 h}$ in $\mathrm{CDCl}_{3}(100 \mathrm{MHz})$
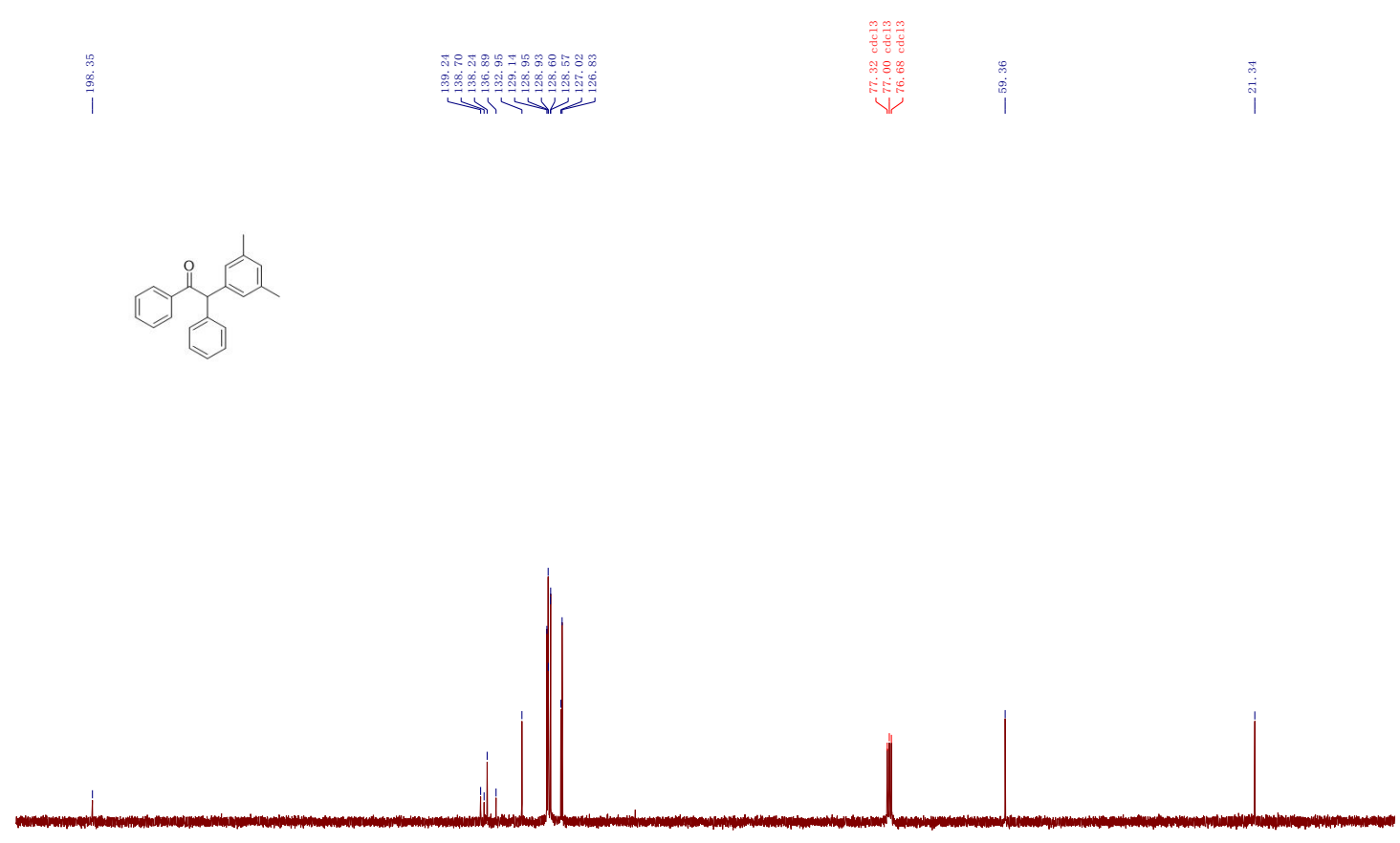

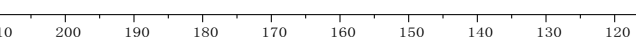


${ }^{\mathbf{1}} \mathbf{H}$ NMR spectrum of $\mathbf{3 i}$ in $\mathrm{CDCl}_{3}(400 \mathrm{MHz})$
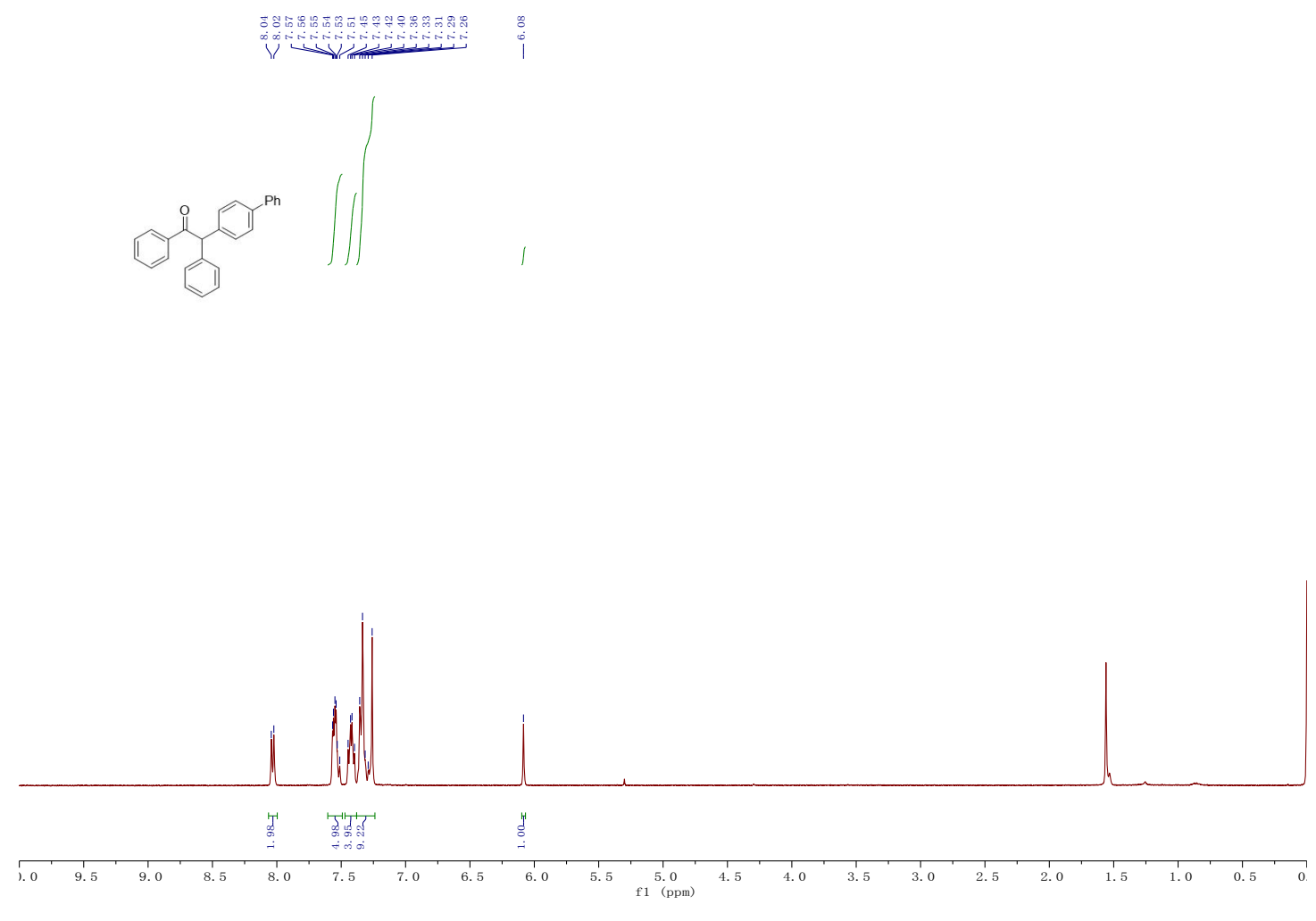

${ }^{13} \mathbf{C}$ NMR spectrum of $\mathbf{3 i}$ in $\mathrm{CDCl}_{3}(100 \mathrm{MHz})$
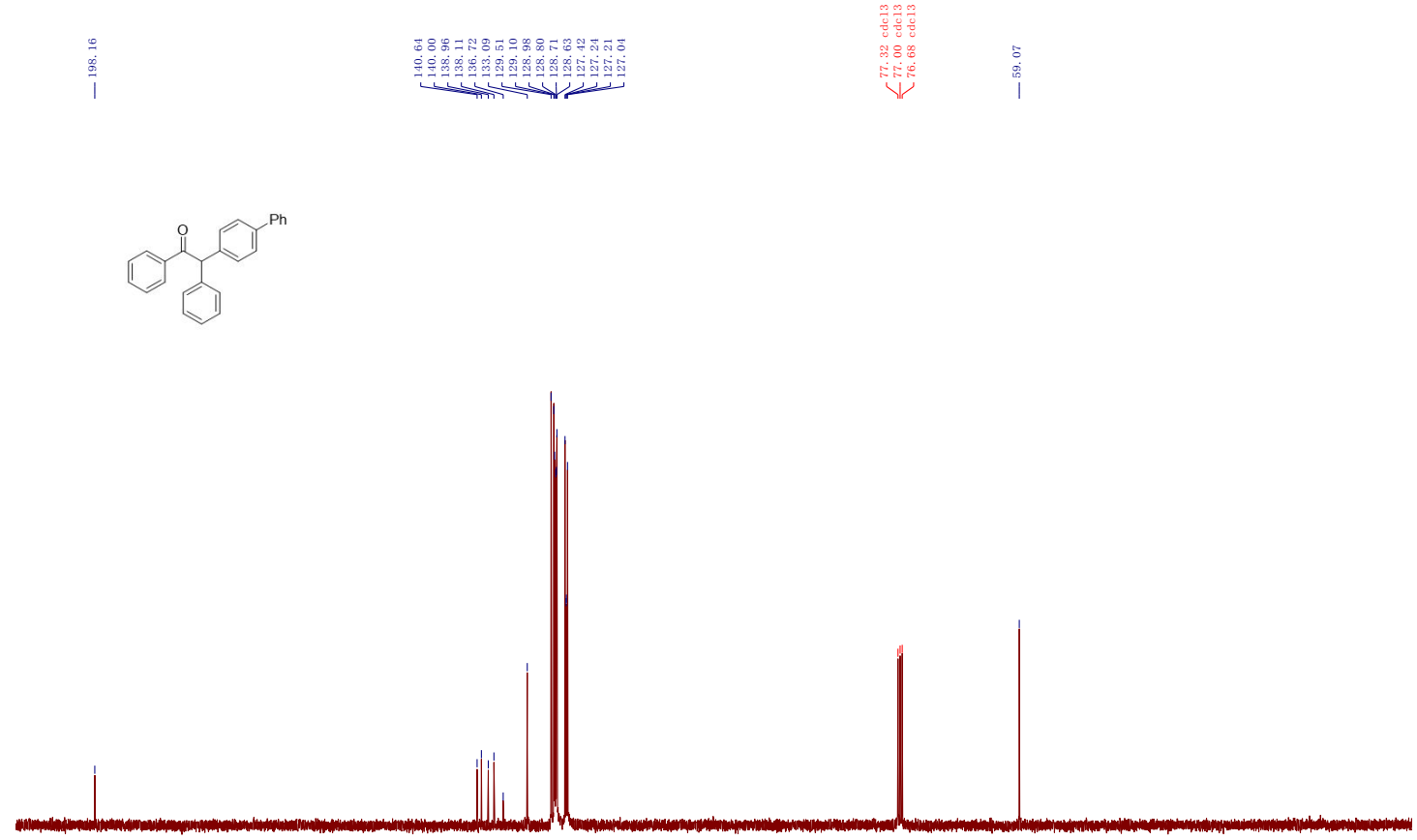

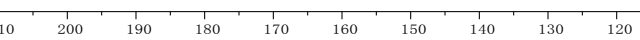

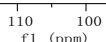


${ }^{\mathbf{1}} \mathbf{H}$ NMR spectrum of $\mathbf{3 j}$ in $\mathrm{CDCl}_{3}(400 \mathrm{MHz})$
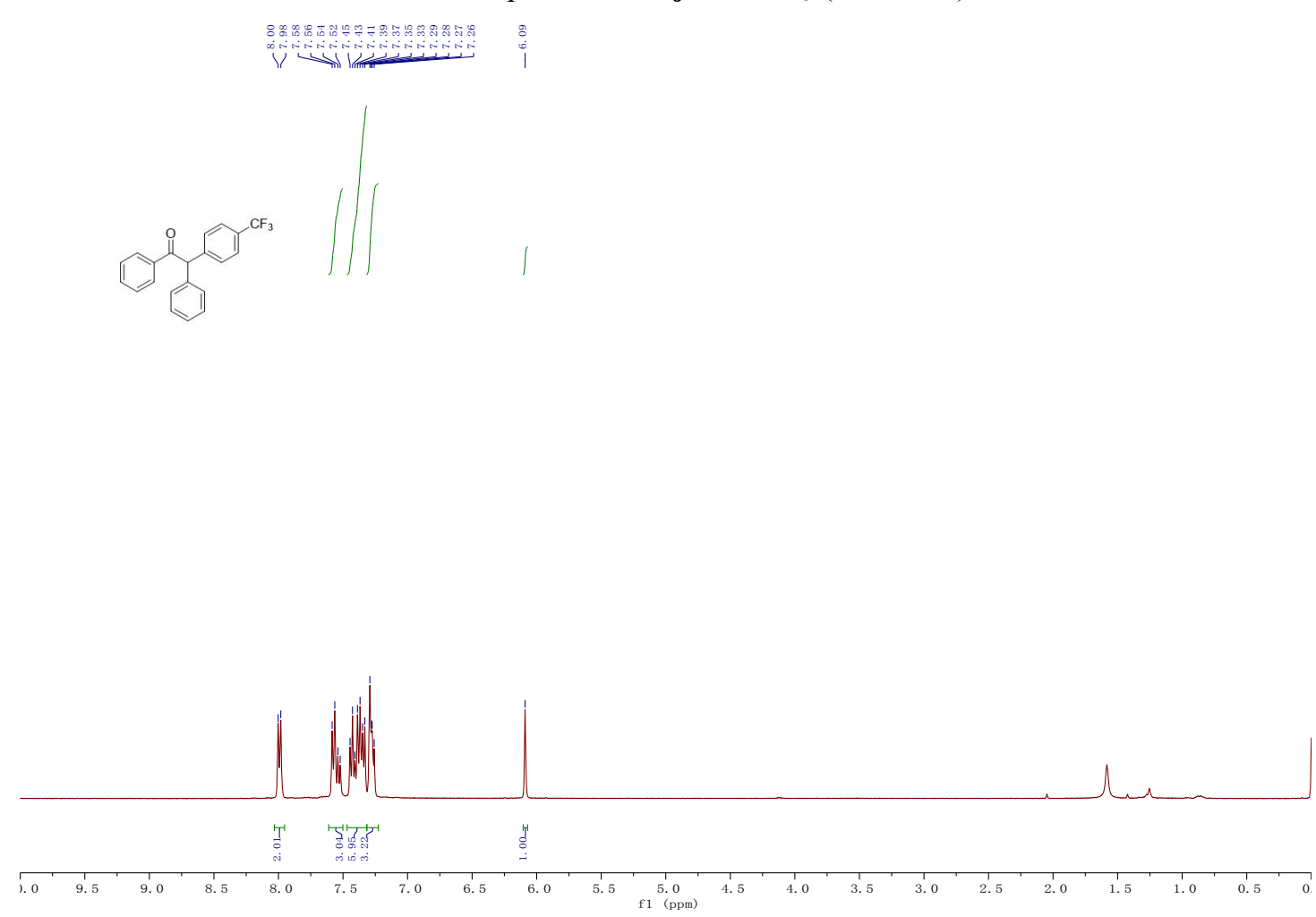

${ }^{13} \mathbf{C}$ NMR spectrum of $\mathbf{3} \mathbf{j}$ in $\mathrm{CDCl}_{3}(100 \mathrm{MHz})$

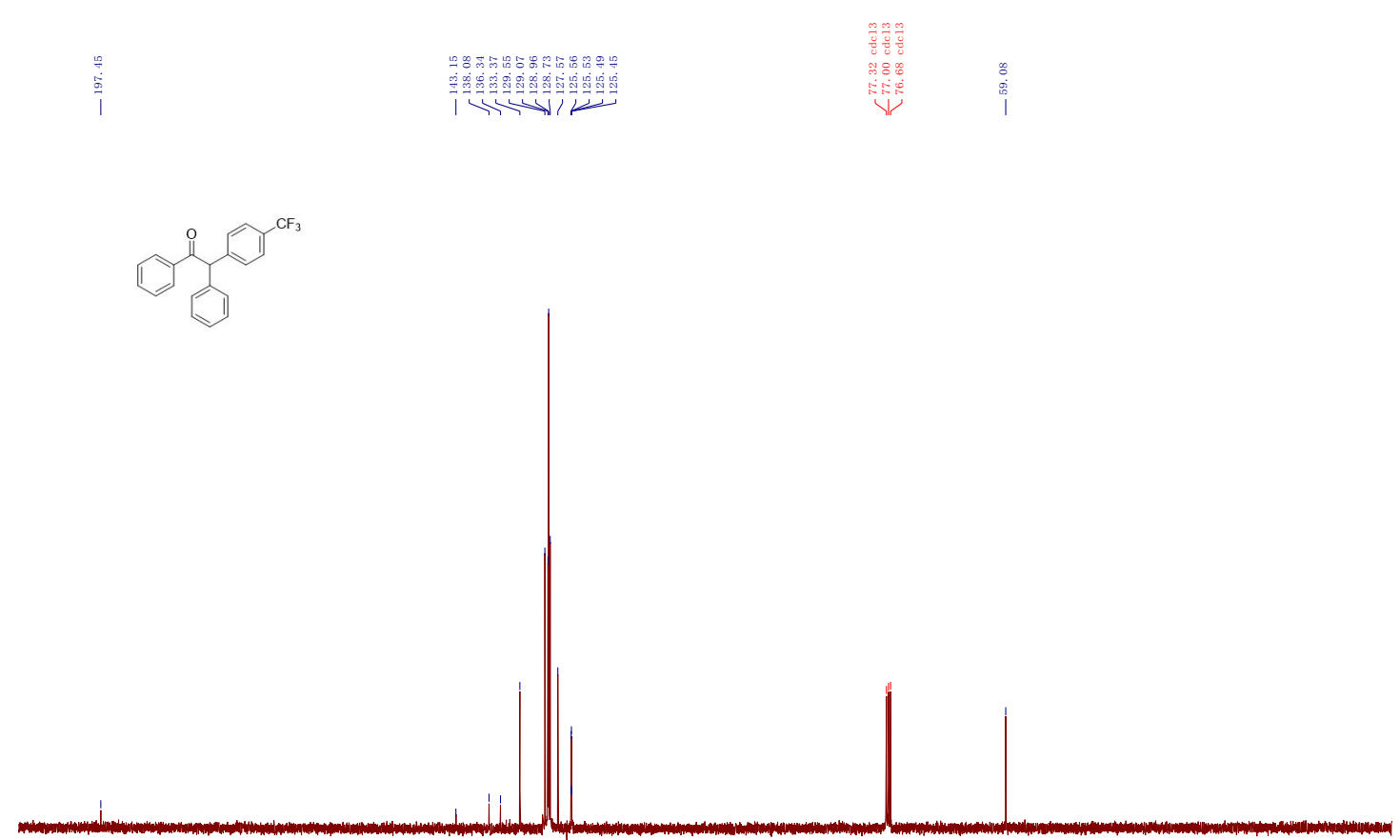

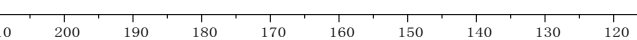

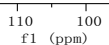


${ }^{19} \mathbf{F}$ NMR spectrum of $\mathbf{3} \mathbf{j}$ in $\mathrm{CDCl}_{3}(376 \mathrm{MHz})$
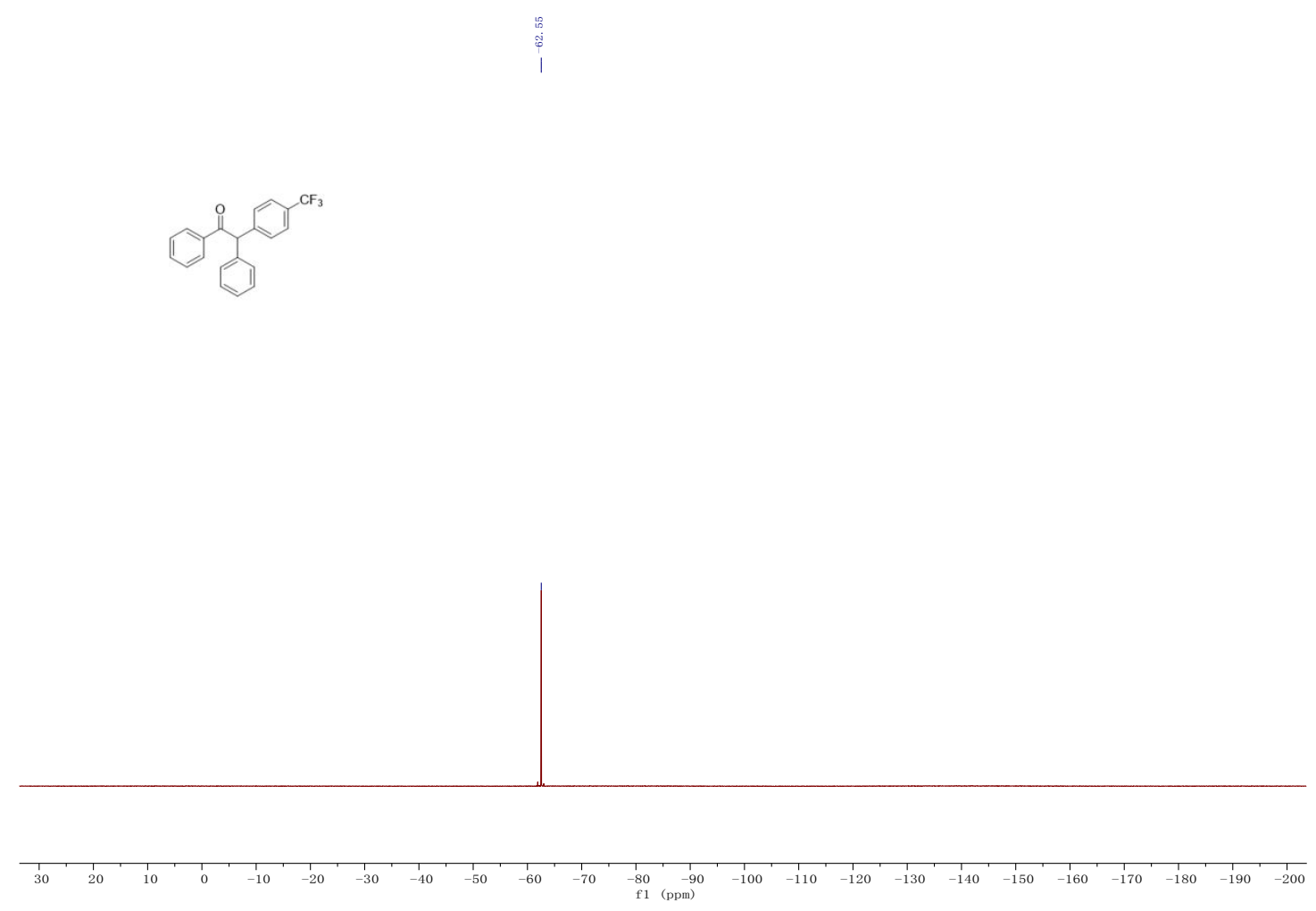

${ }^{\mathbf{1}} \mathbf{H} \mathbf{N M R}$ spectrum of $\mathbf{3 k}$ in $\mathrm{CDCl}_{3}(400 \mathrm{MHz})$
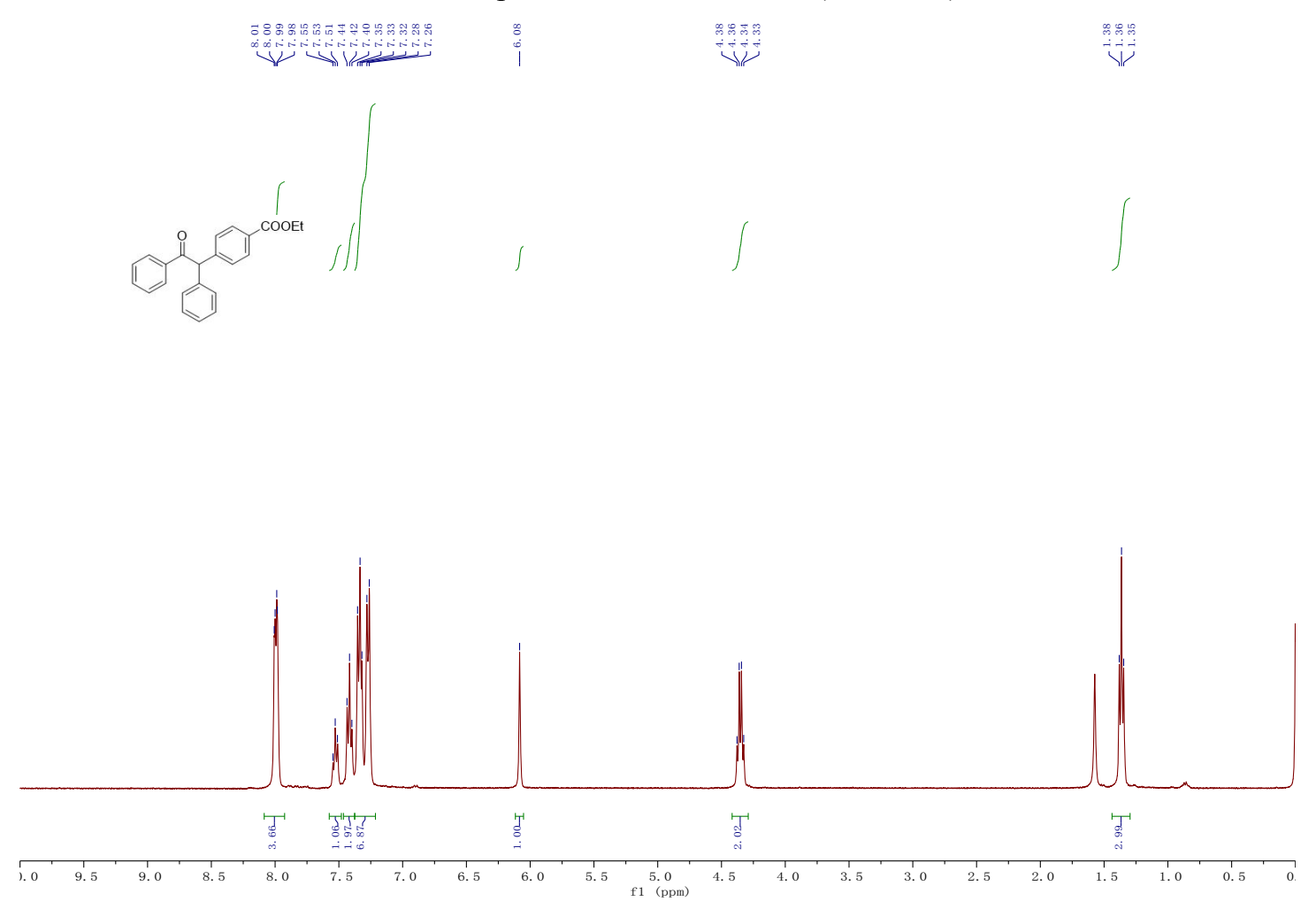
${ }^{13} \mathbf{C}$ NMR spectrum of $\mathbf{3 k}$ in $\mathrm{CDCl}_{3}(100 \mathrm{MHz})$

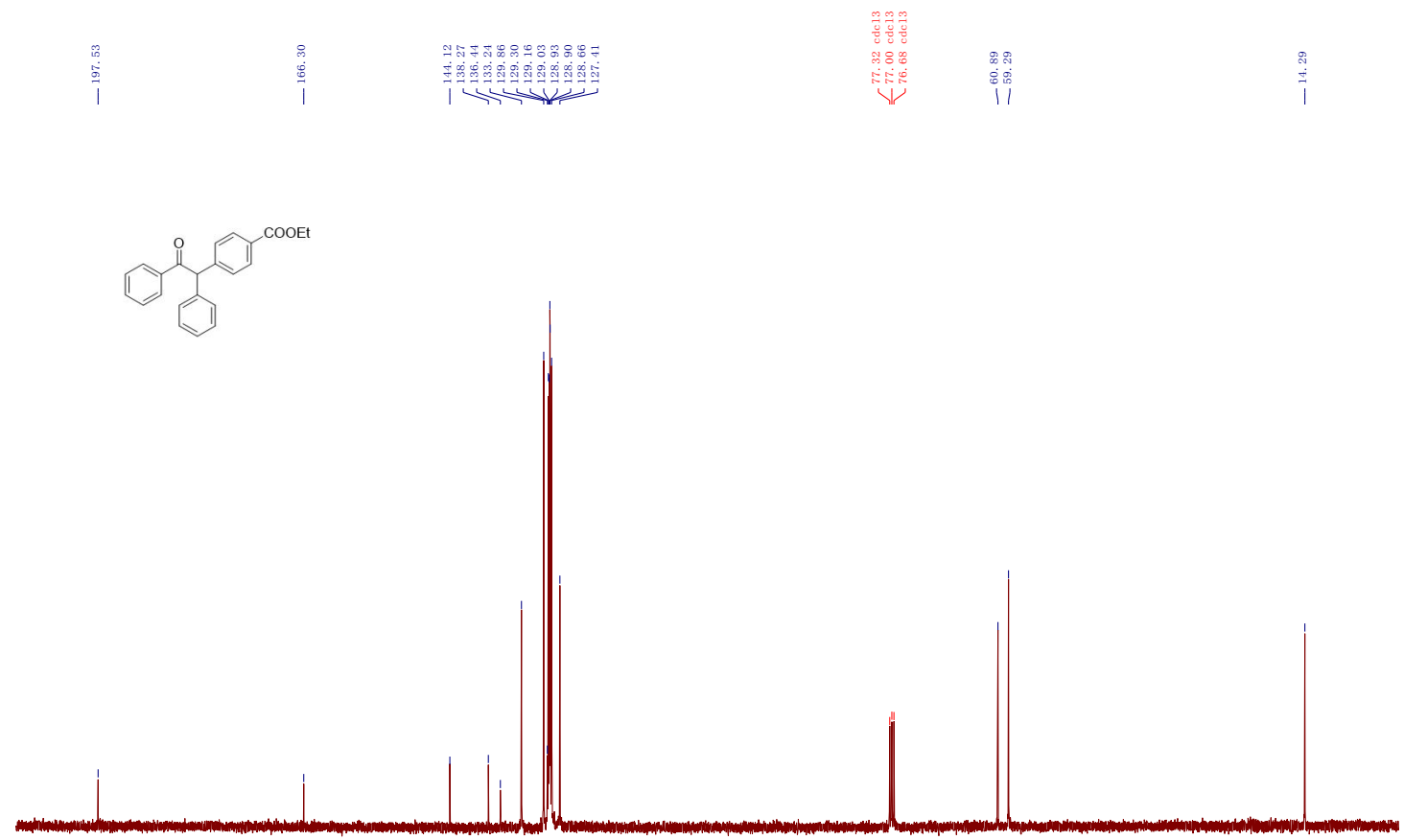

${ }^{\mathbf{1}} \mathbf{H}$ NMR spectrum of $\mathbf{3 l}$ in $\mathrm{CDCl}_{3}(400 \mathrm{MHz})$
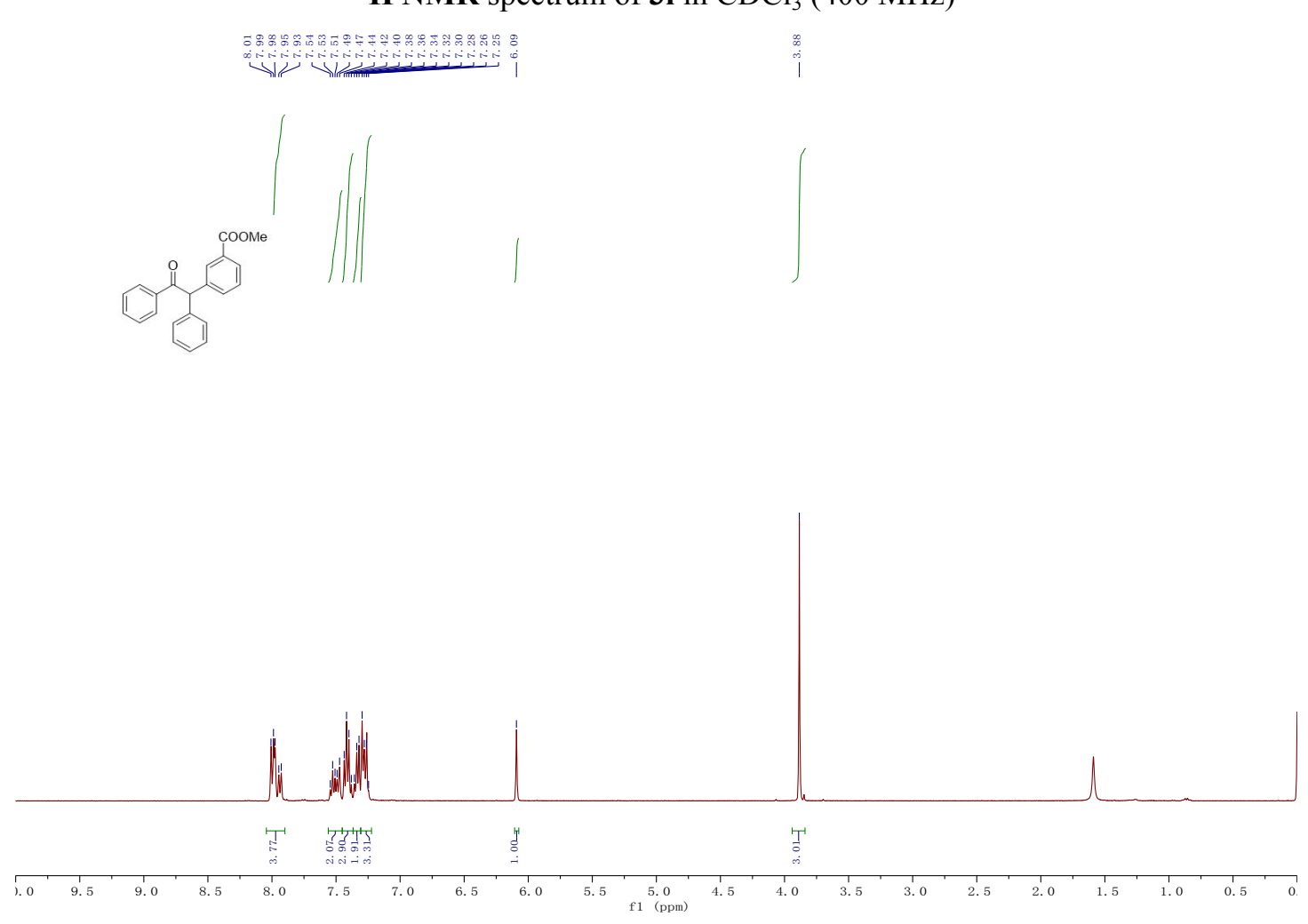
${ }^{13} \mathbf{C}$ NMR spectrum of 31 in $\mathrm{CDCl}_{3}(100 \mathrm{MHz})$
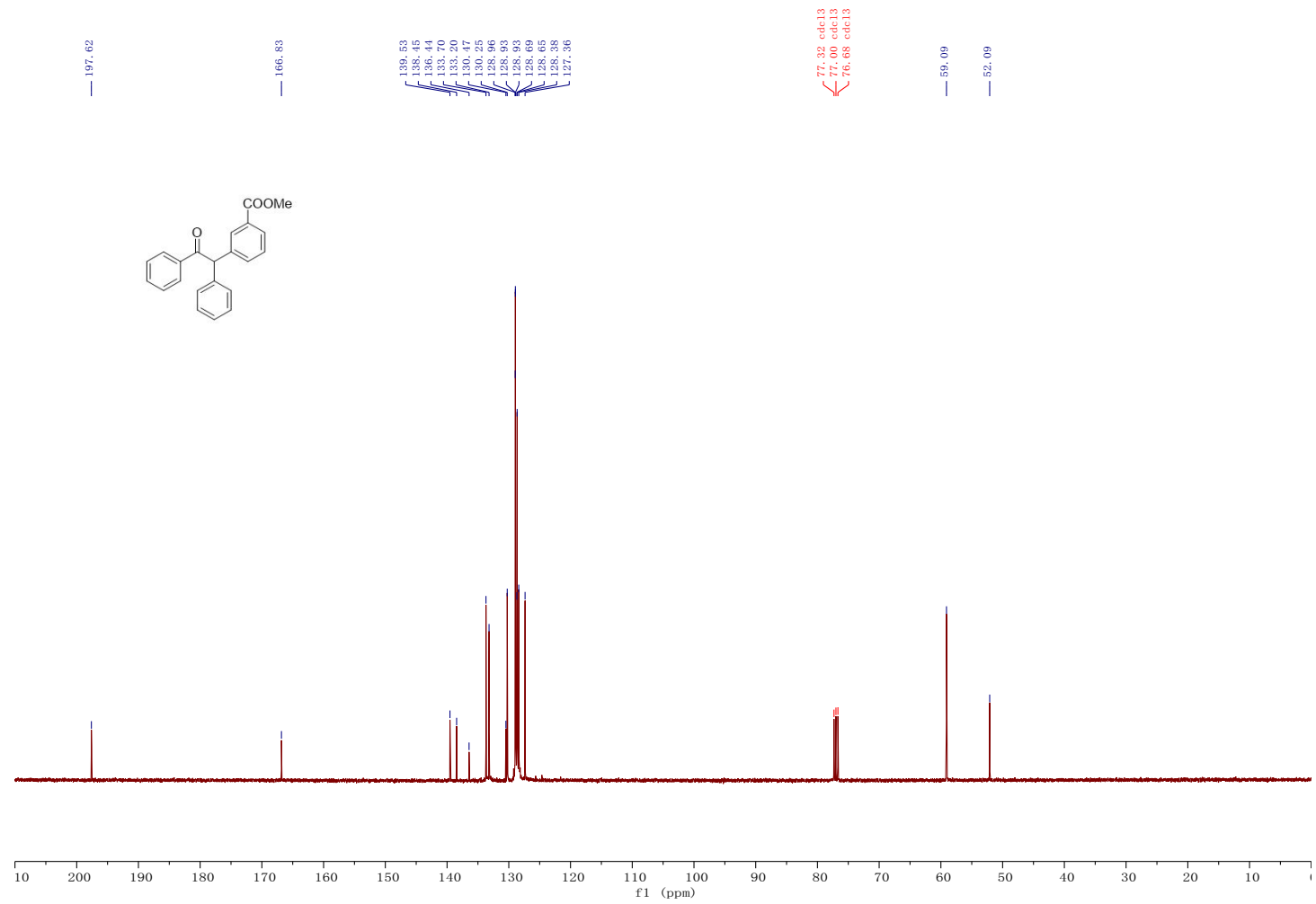

${ }^{1} \mathbf{H}$ NMR spectrum of $\mathbf{3 m}$ in $\mathrm{CDCl}_{3}(400 \mathrm{MHz})$
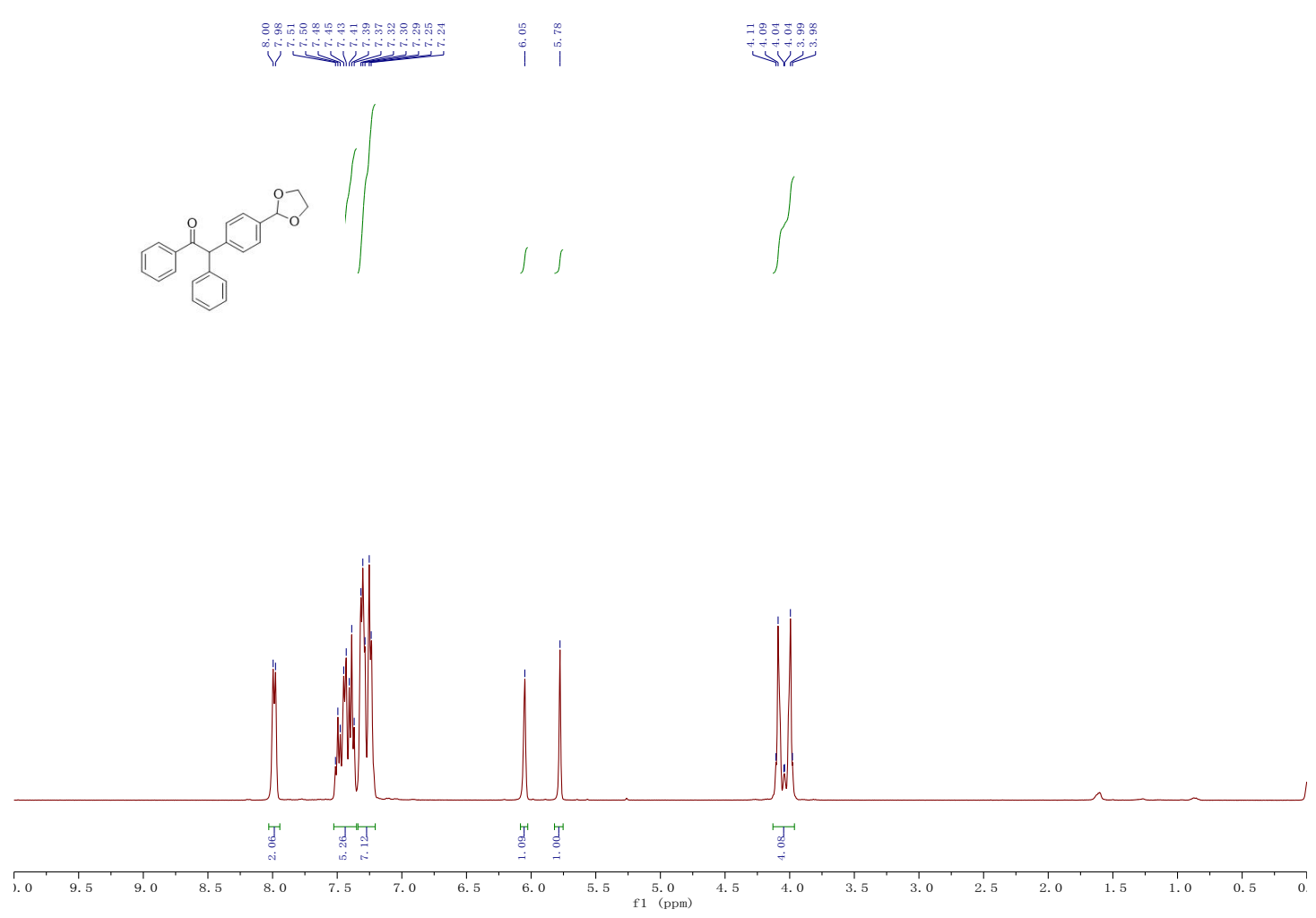
${ }^{13} \mathbf{C}$ NMR spectrum of $\mathbf{3 m}$ in $\mathrm{CDCl}_{3}(100 \mathrm{MHz})$

及๐ละ

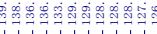

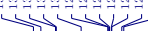

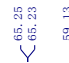
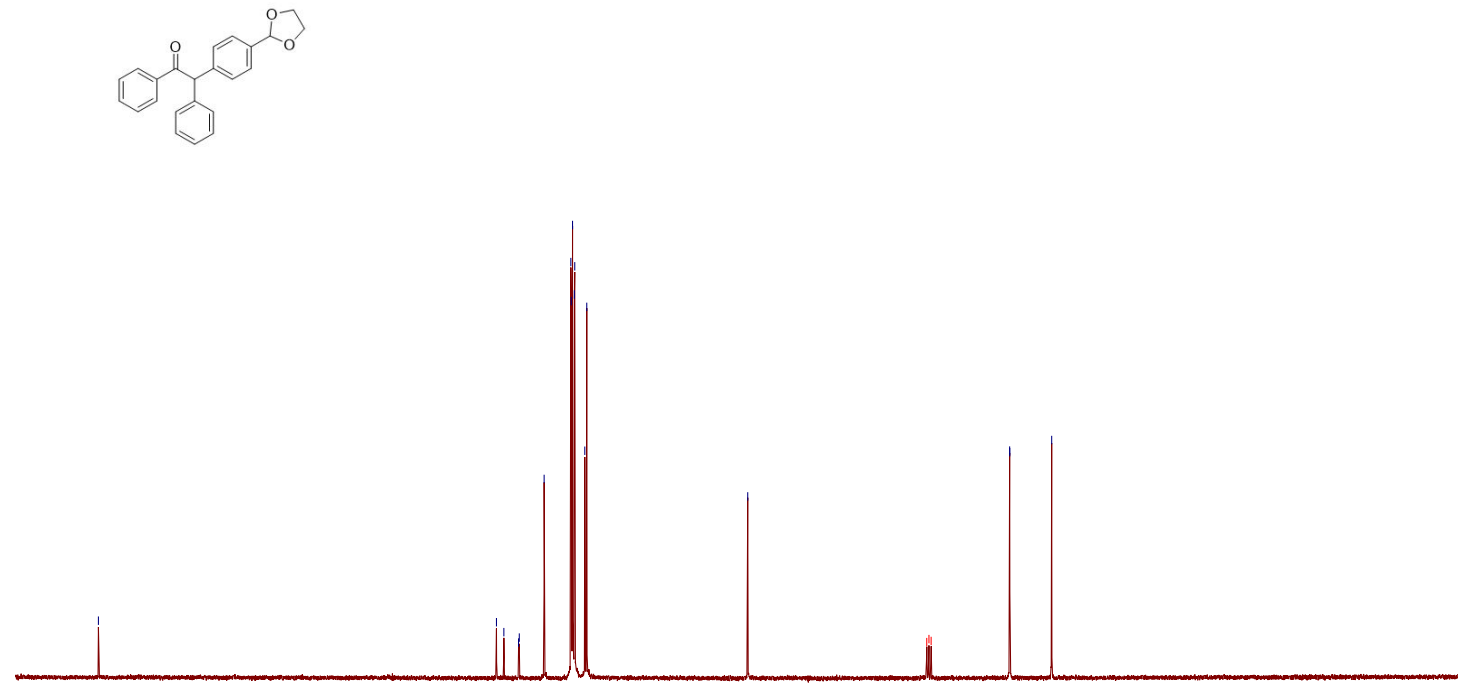

${ }^{1} \mathbf{H}$ NMR spectrum of $\mathbf{3 n}$ in $\mathrm{CDCl}_{3}(400 \mathrm{MHz})$

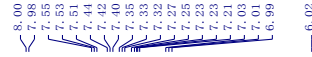
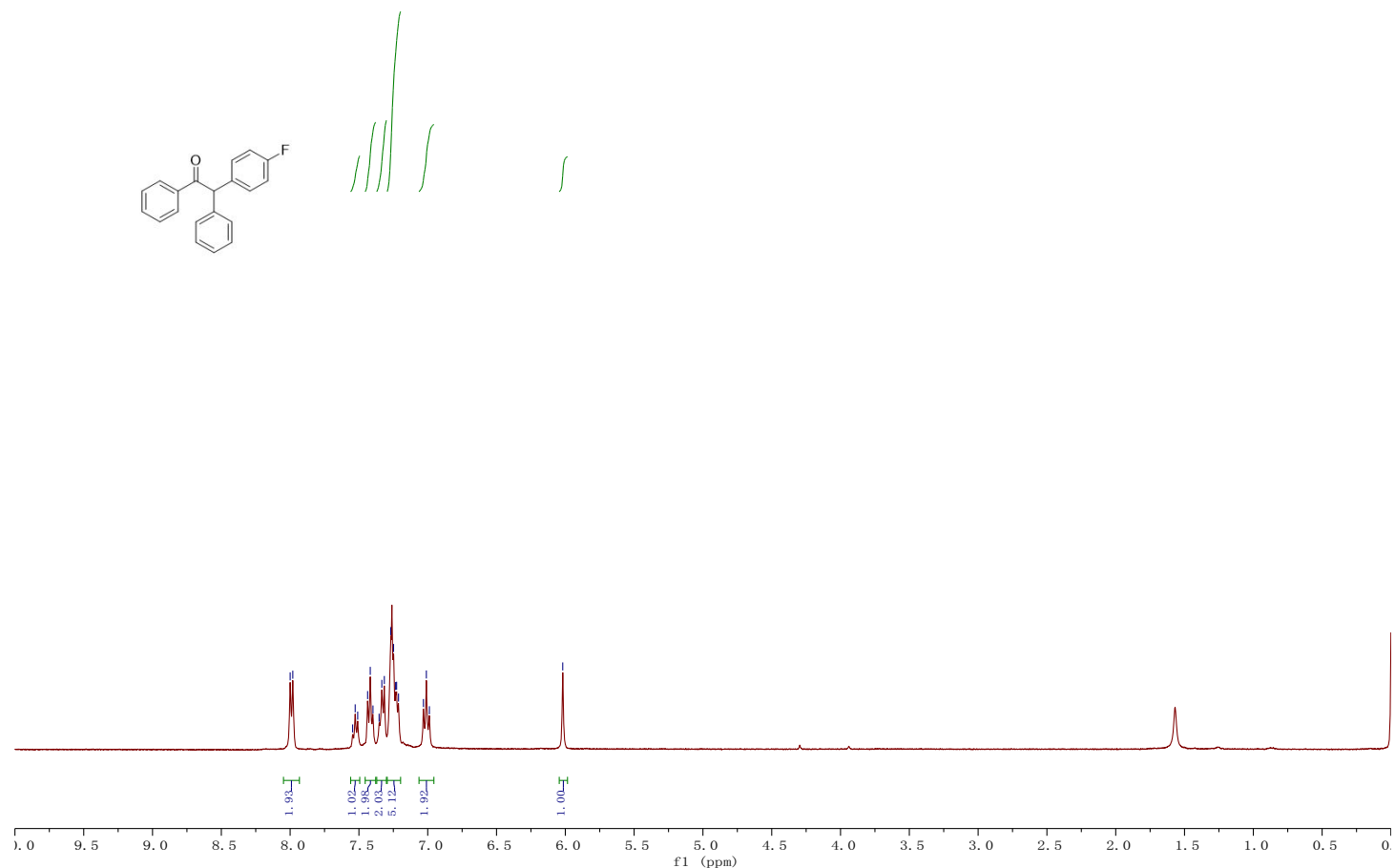
${ }^{13} \mathbf{C}$ NMR spectrum of $\mathbf{3 n}$ in $\mathrm{CDCl}_{3}(100 \mathrm{MHz})$
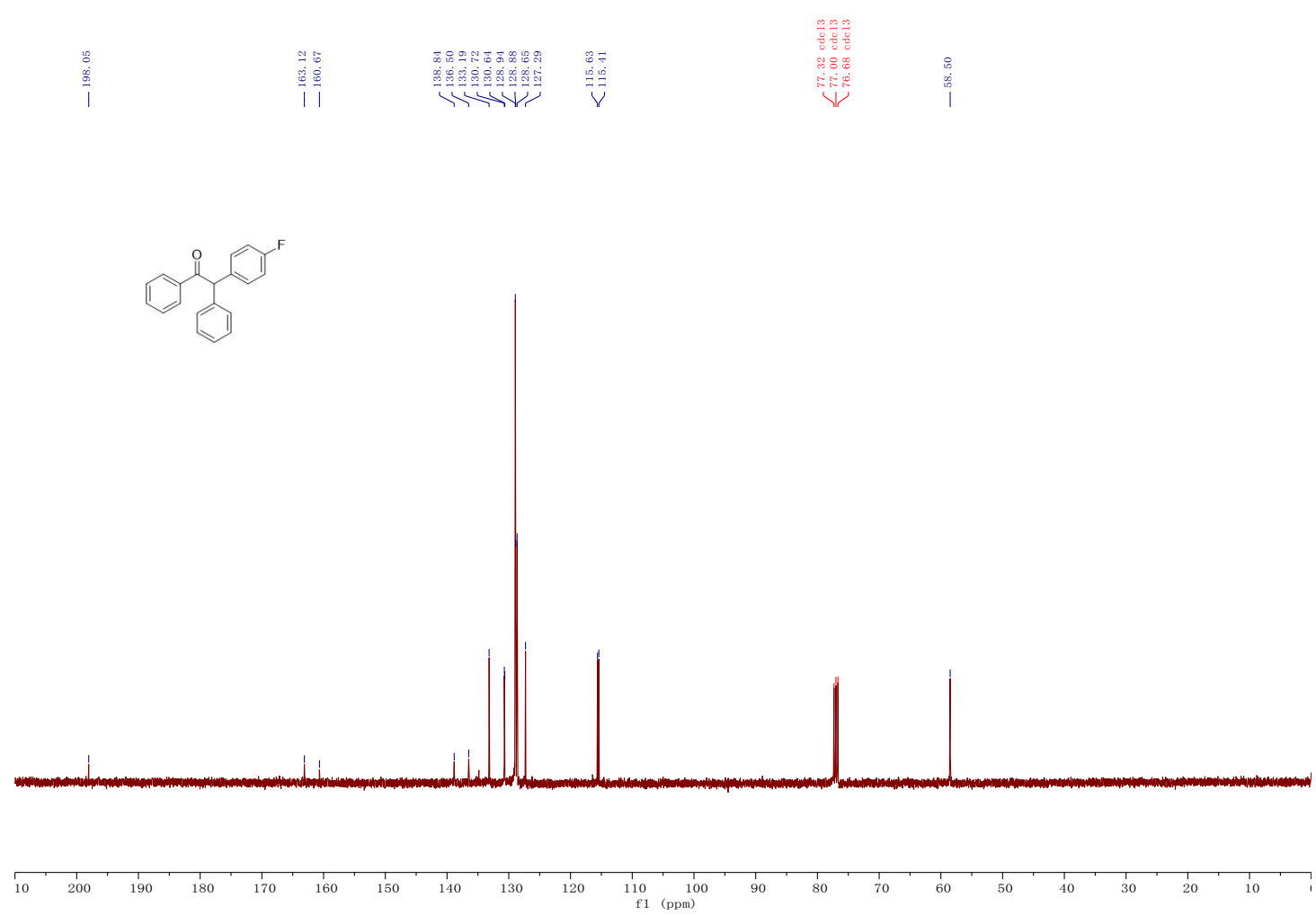

${ }^{19} \mathbf{F}$ NMR spectrum of $\mathbf{3 n}$ in $\mathrm{CDCl}_{3}(376 \mathrm{MHz})$

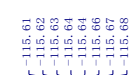

它
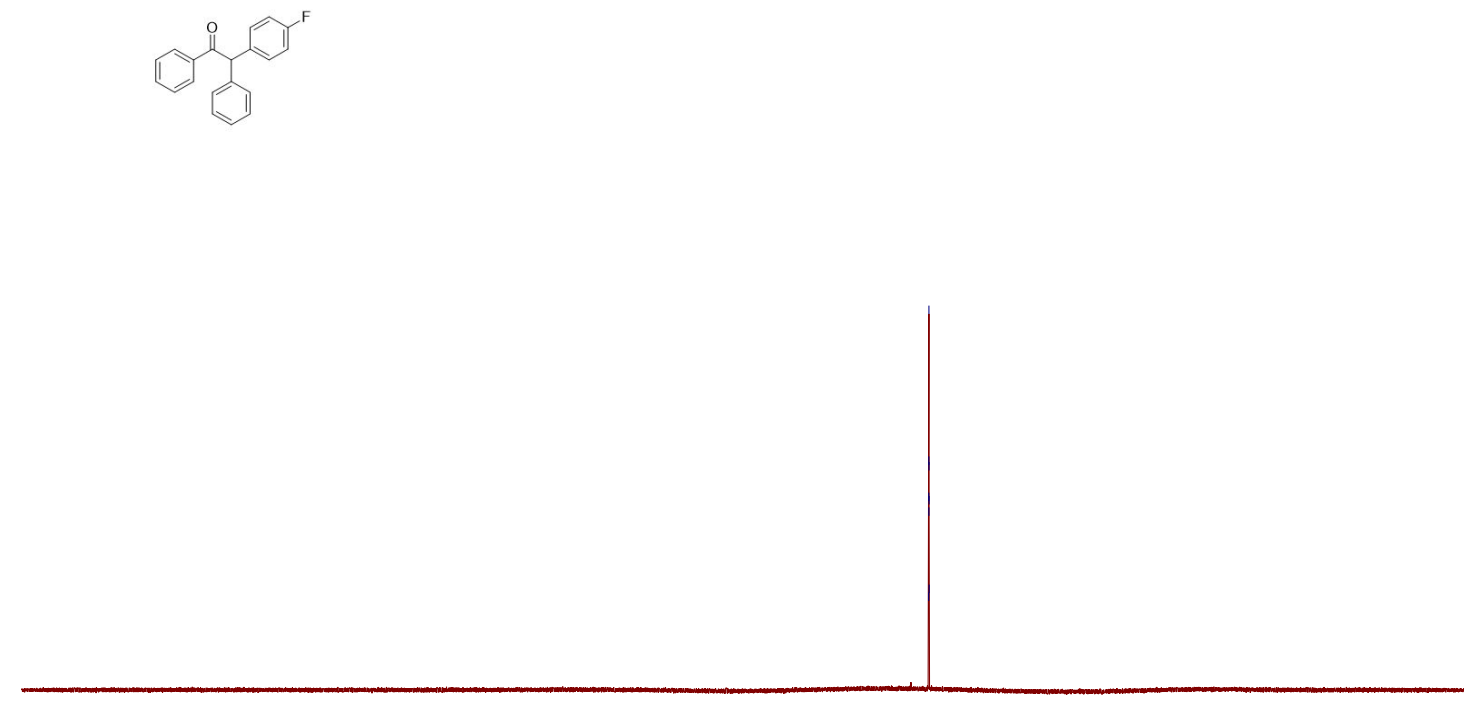

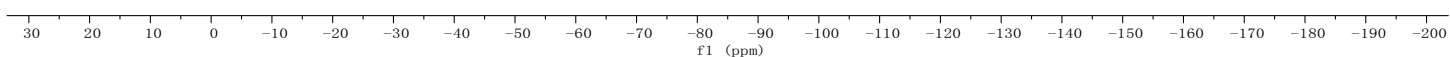


${ }^{1} \mathbf{H}$ NMR spectrum of $\mathbf{3 o}$ in $\mathrm{CDCl}_{3}(400 \mathrm{MHz})$

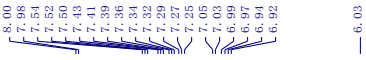
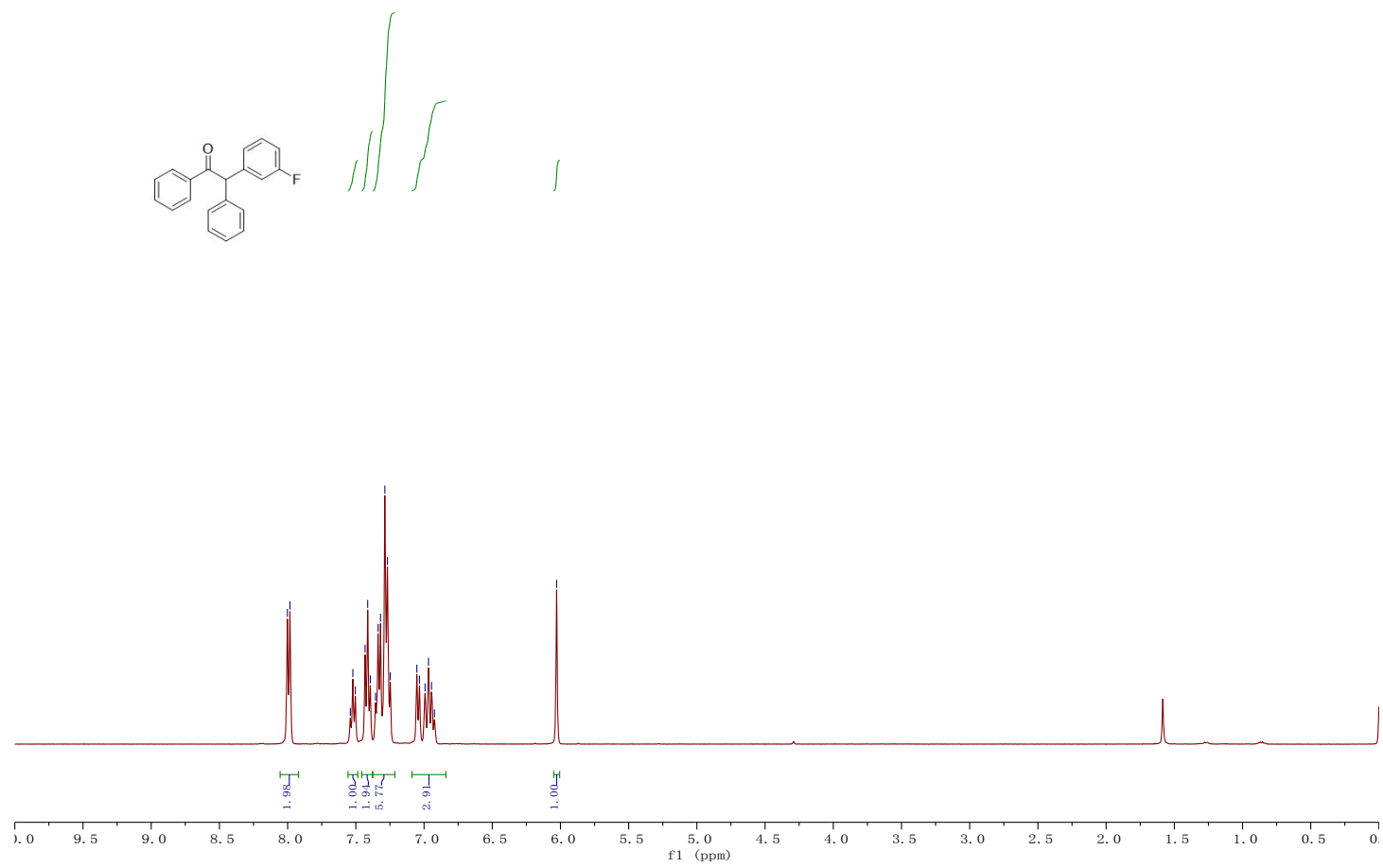

${ }^{13} \mathbf{C}$ NMR spectrum of 30 in $\mathrm{CDCl}_{3}(100 \mathrm{MHz})$

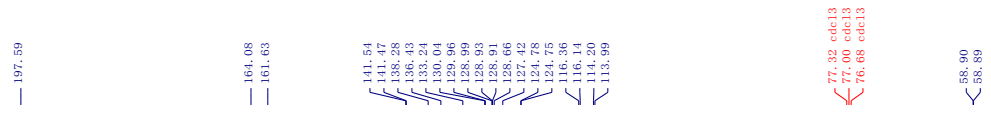

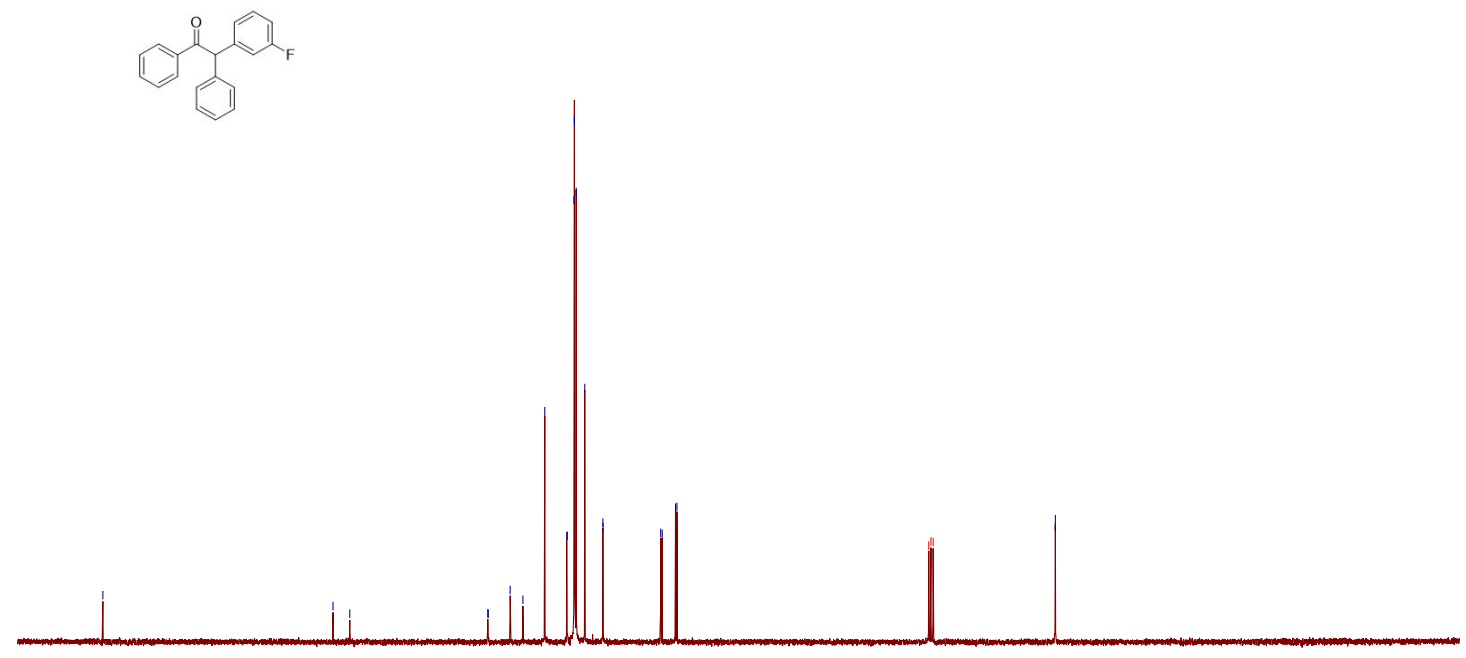

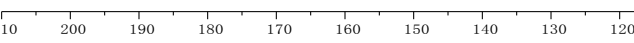


${ }^{19} \mathbf{F}$ NMR spectrum of 30 in $\mathrm{CDCl}_{3}(376 \mathrm{MHz})$

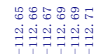

w
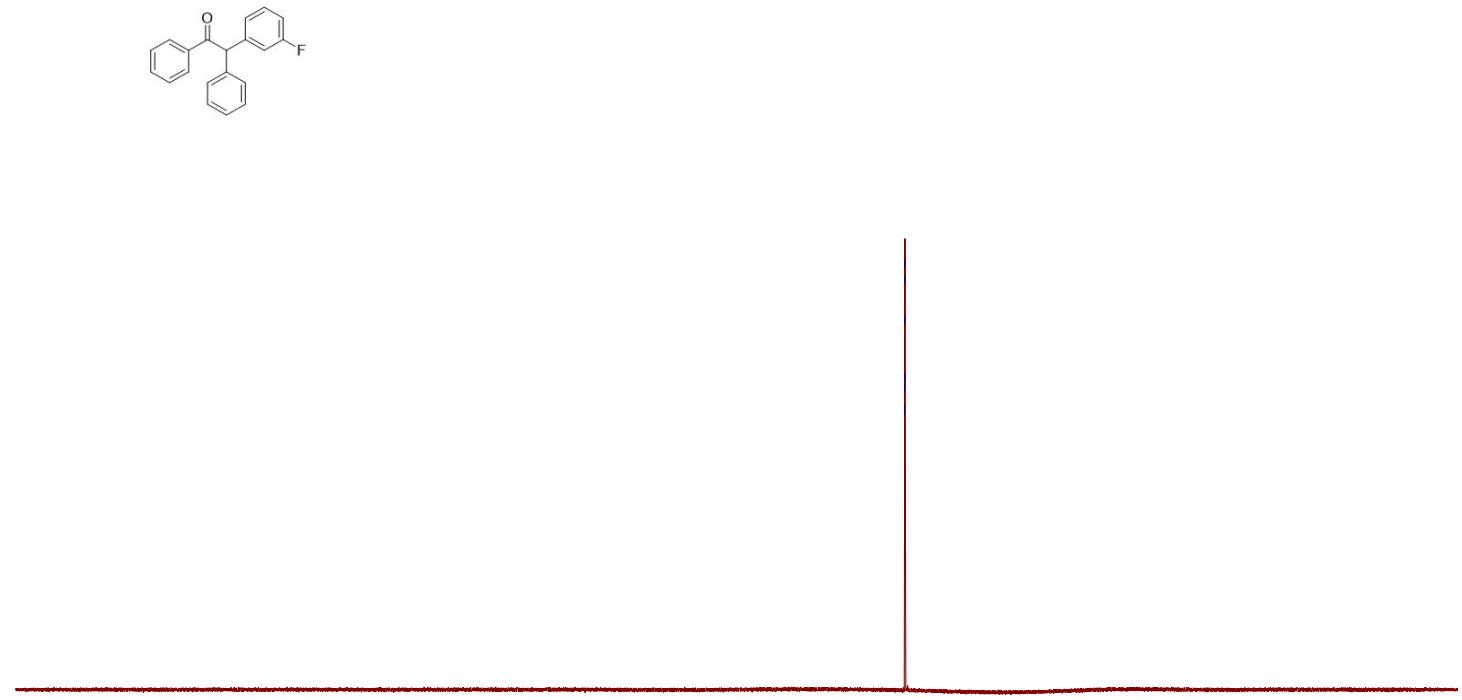

${ }^{1} \mathbf{H}$ NMR spectrum of $\mathbf{3 p}$ in $\mathrm{CDCl}_{3}(400 \mathrm{MHz})$

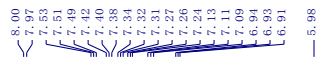
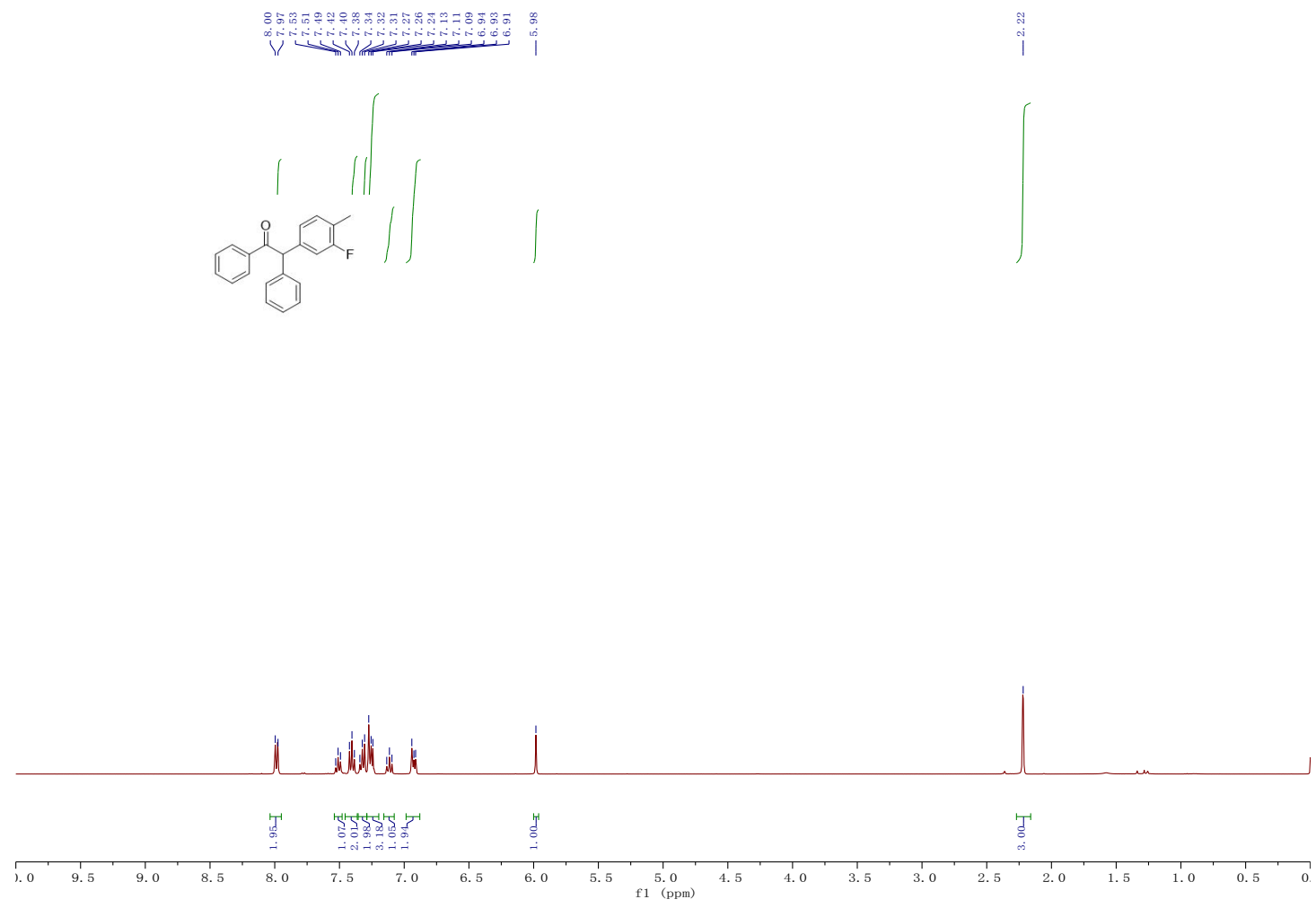
${ }^{13} \mathbf{C}$ NMR spectrum of $\mathbf{3 p}$ in $\mathrm{CDCl}_{3}(100 \mathrm{MHz})$
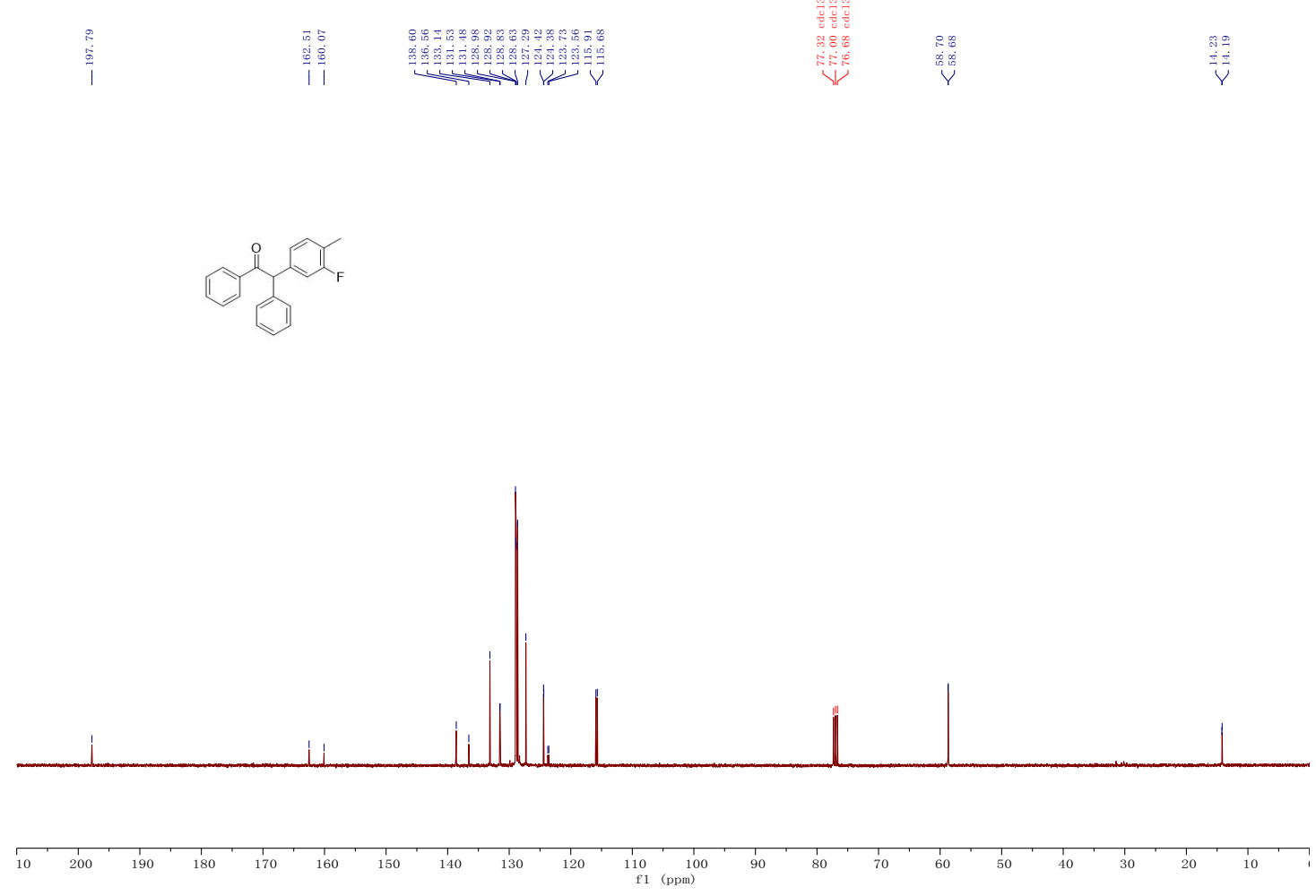

${ }^{19} \mathbf{F}$ NMR spectrum of $\mathbf{3 p}$ in $\mathrm{CDCl}_{3}(376 \mathrm{MHz})$
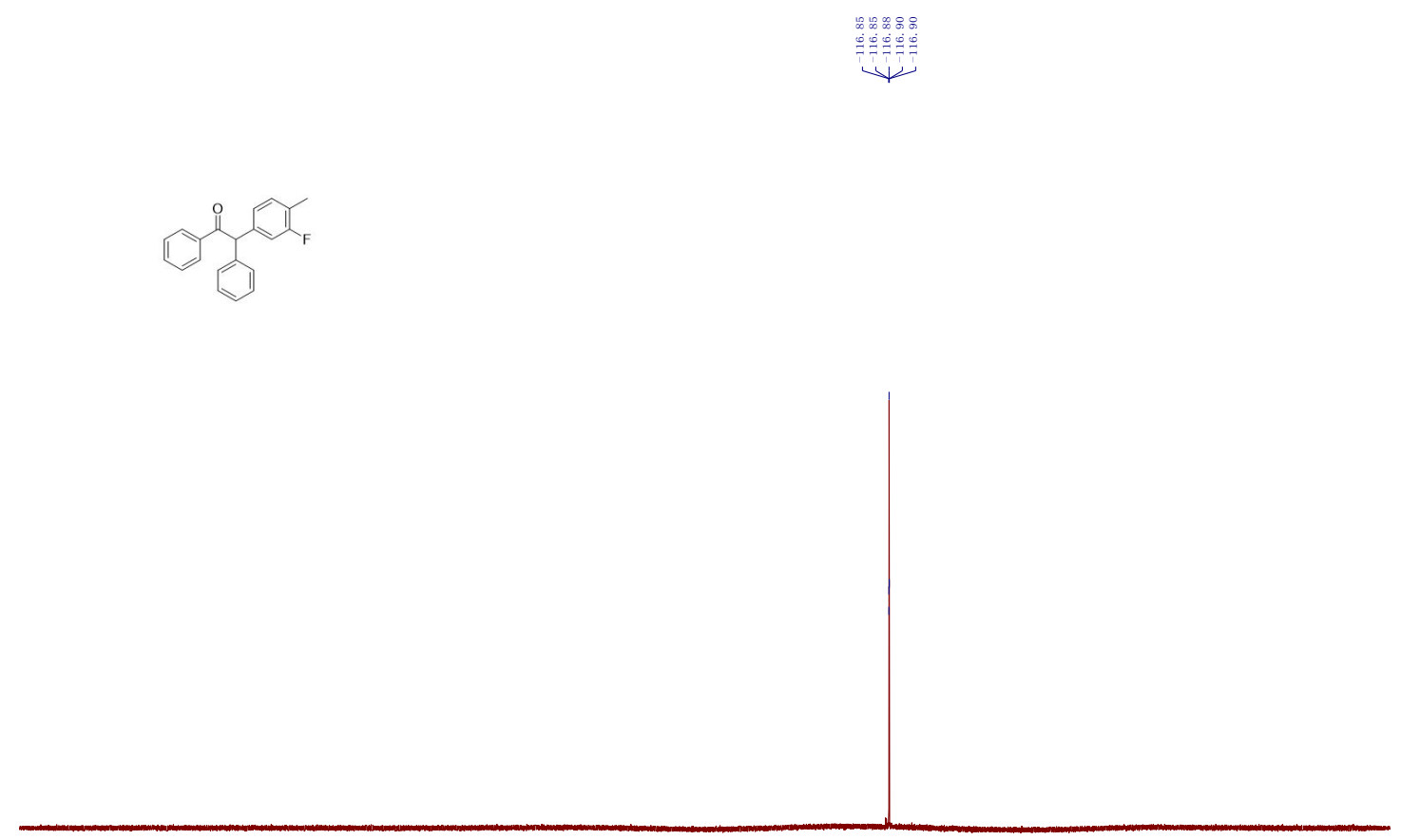

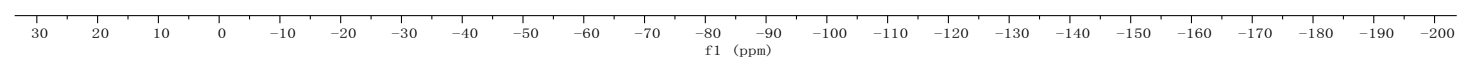


${ }^{\mathbf{1}} \mathbf{H}$ NMR spectrum of $\mathbf{3 q}$ in $\mathrm{CDCl}_{3}(400 \mathrm{MHz})$

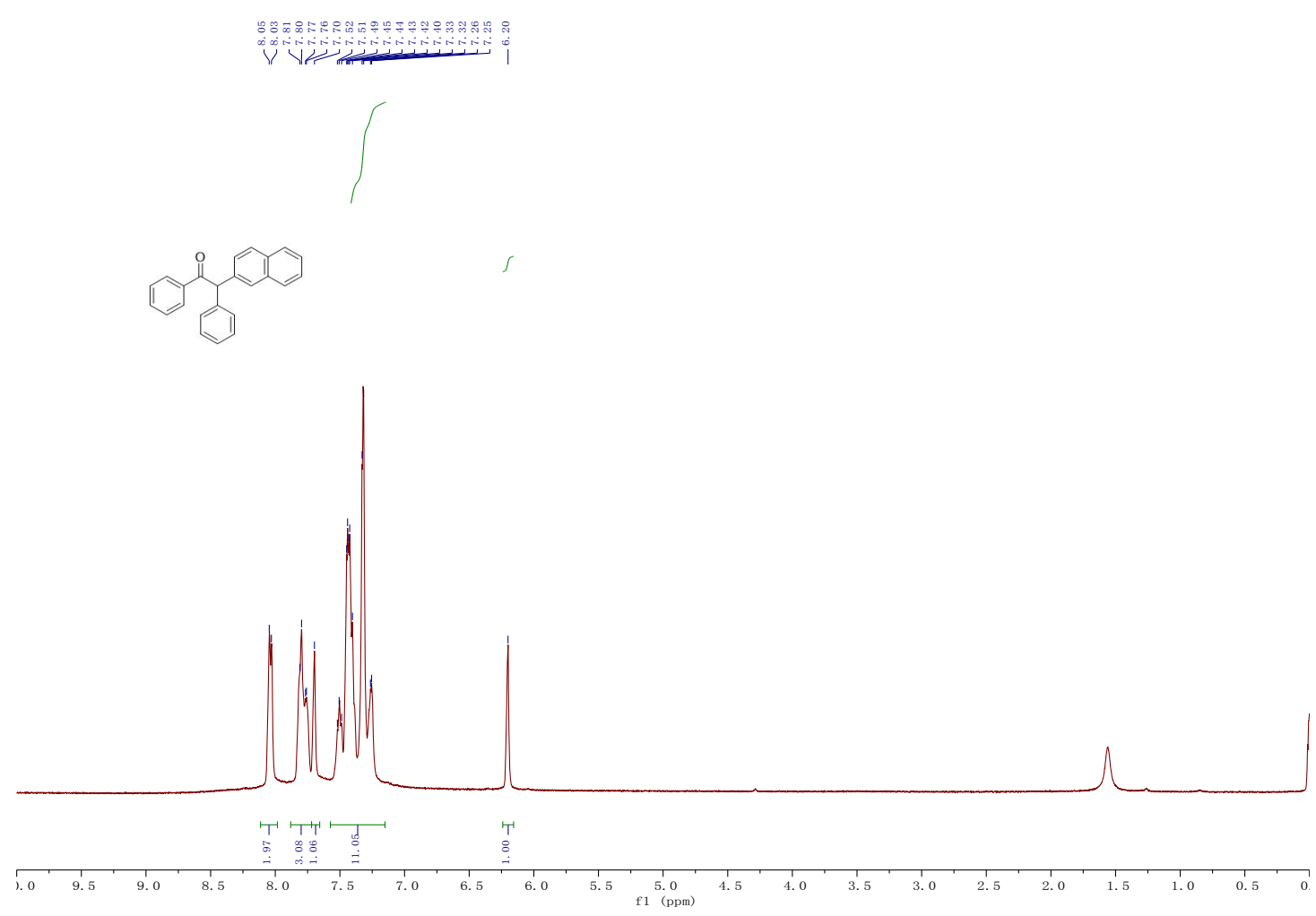

${ }^{13} \mathbf{C}$ NMR spectrum of $\mathbf{3 q}$ in $\mathrm{CDCl}_{3}(100 \mathrm{MHz})$

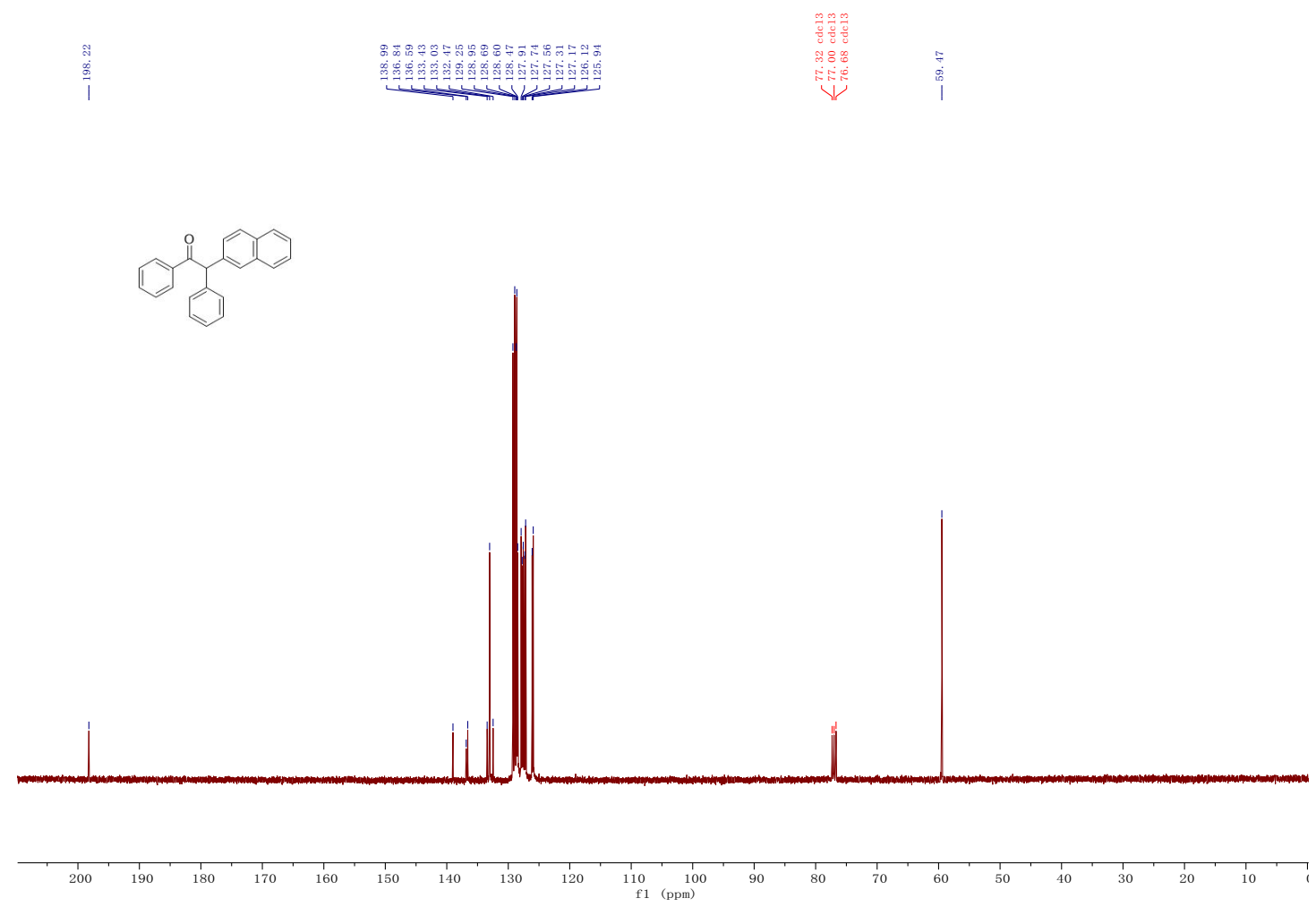


${ }^{1} \mathbf{H}$ NMR spectrum of $\mathbf{3 r}$ in $\mathrm{CDCl}_{3}(400 \mathrm{MHz})$
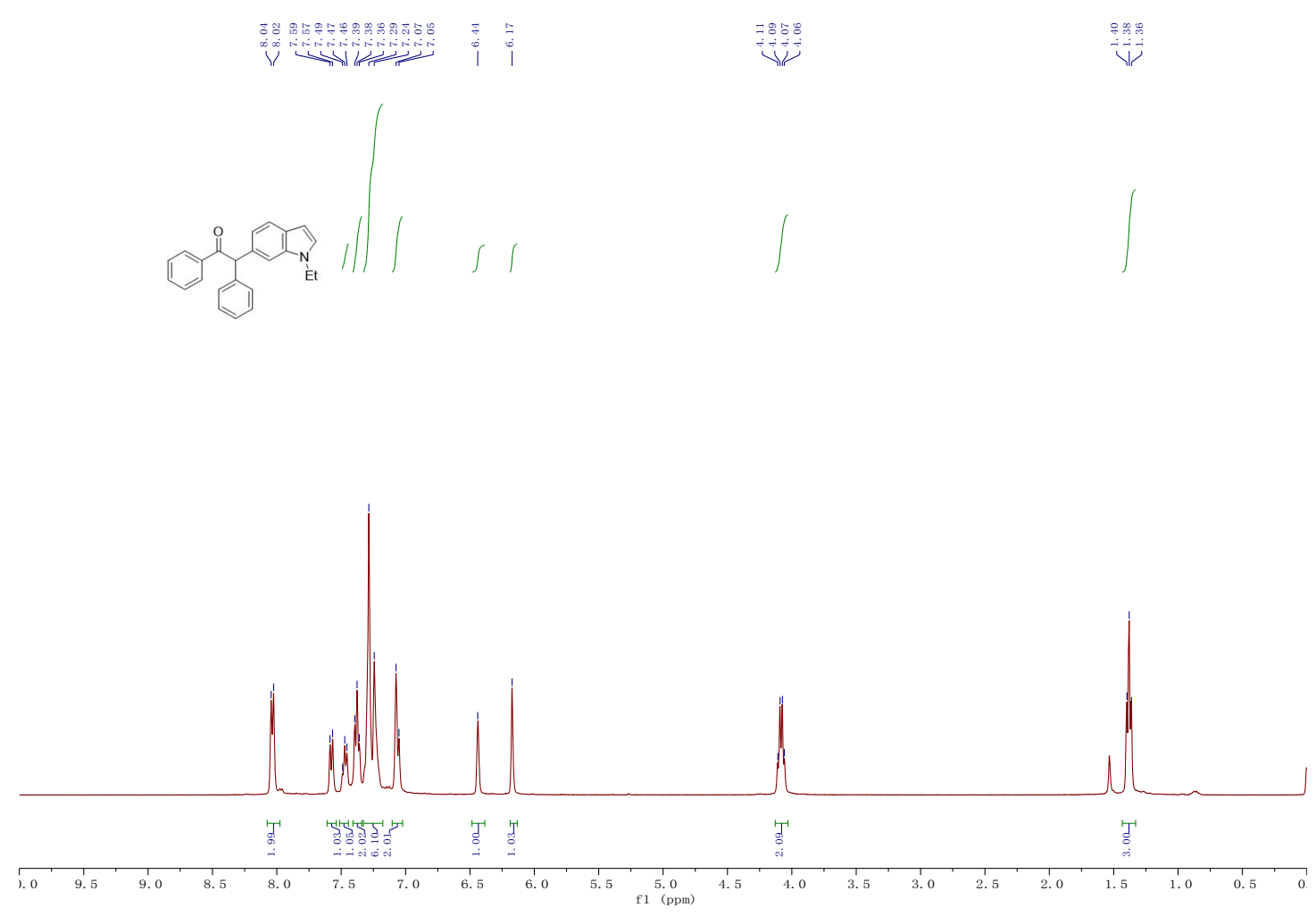

${ }^{13} \mathbf{C}$ NMR spectrum of $3 \mathbf{r}$ in $\mathrm{CDCl}_{3}(100 \mathrm{MHz})$

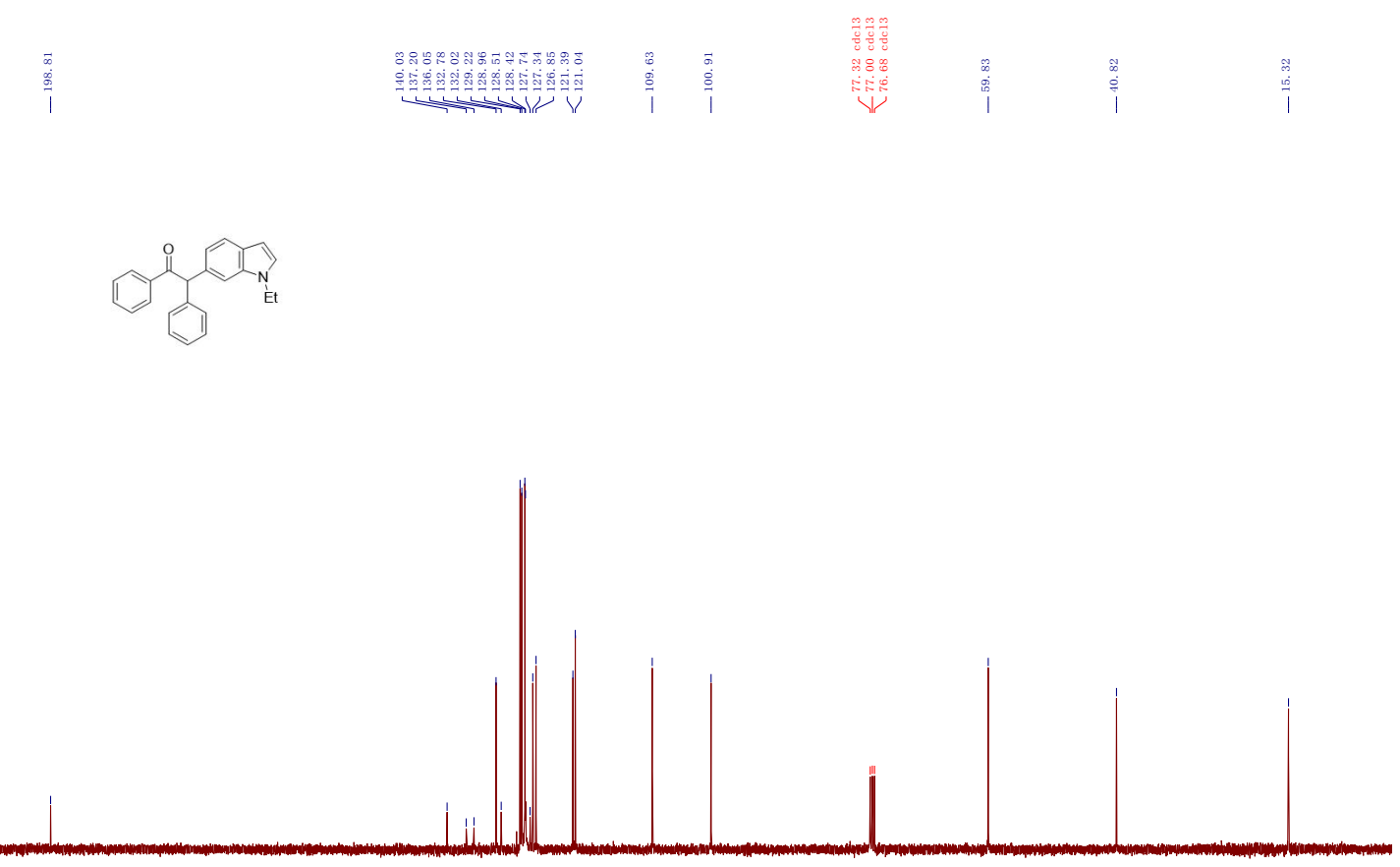

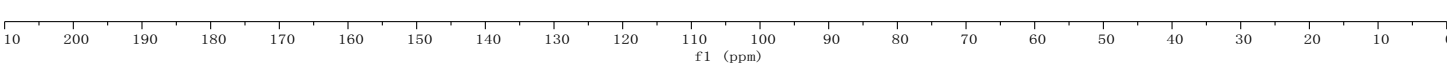


${ }^{1} \mathbf{H}$ NMR spectrum of $3 \mathbf{s}$ in $\mathrm{CDCl}_{3}(400 \mathrm{MHz})$
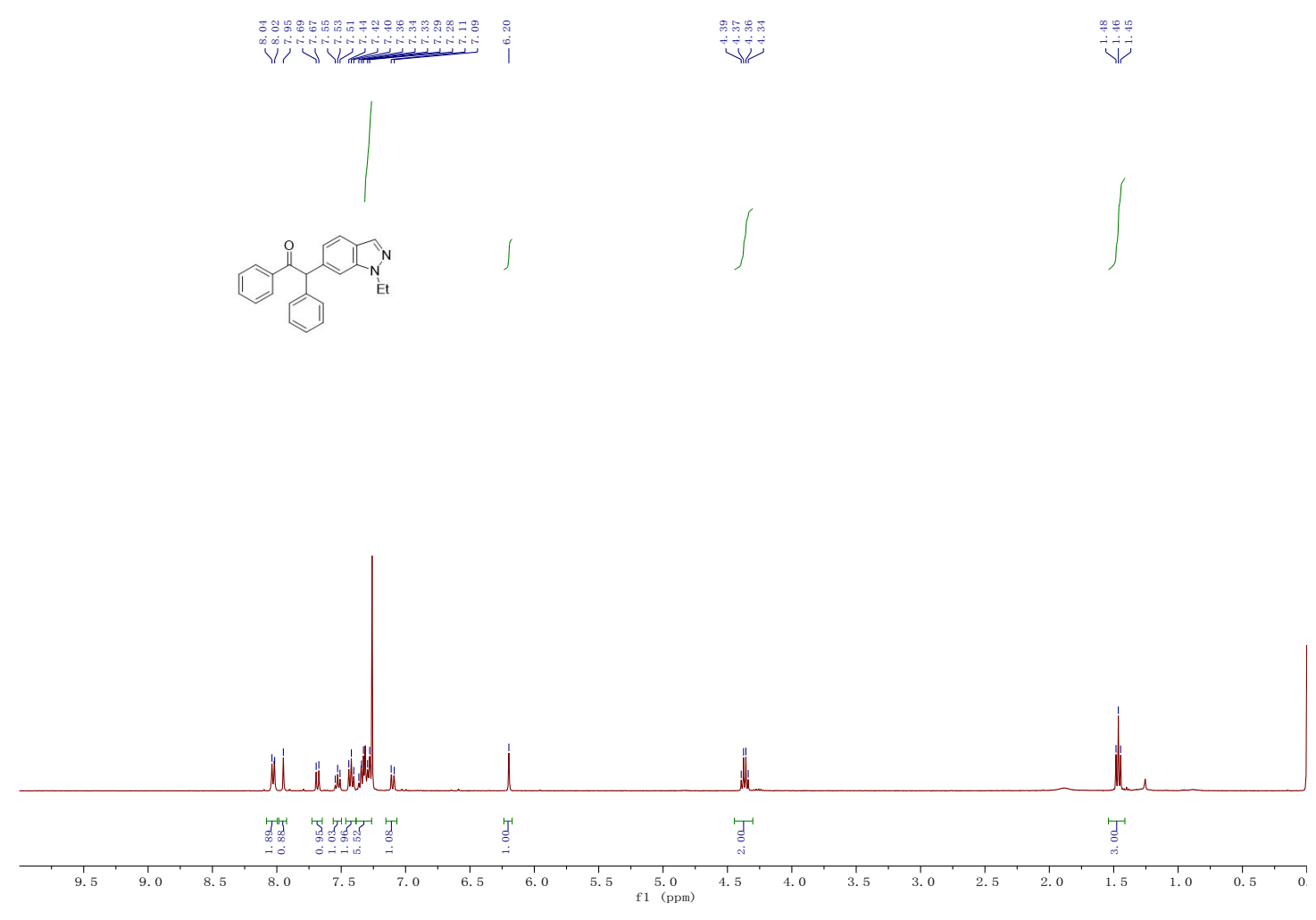

${ }^{13} \mathbf{C}$ NMR spectrum of $3 \mathrm{~s}$ in $\mathrm{CDCl}_{3}(100 \mathrm{MHz})$

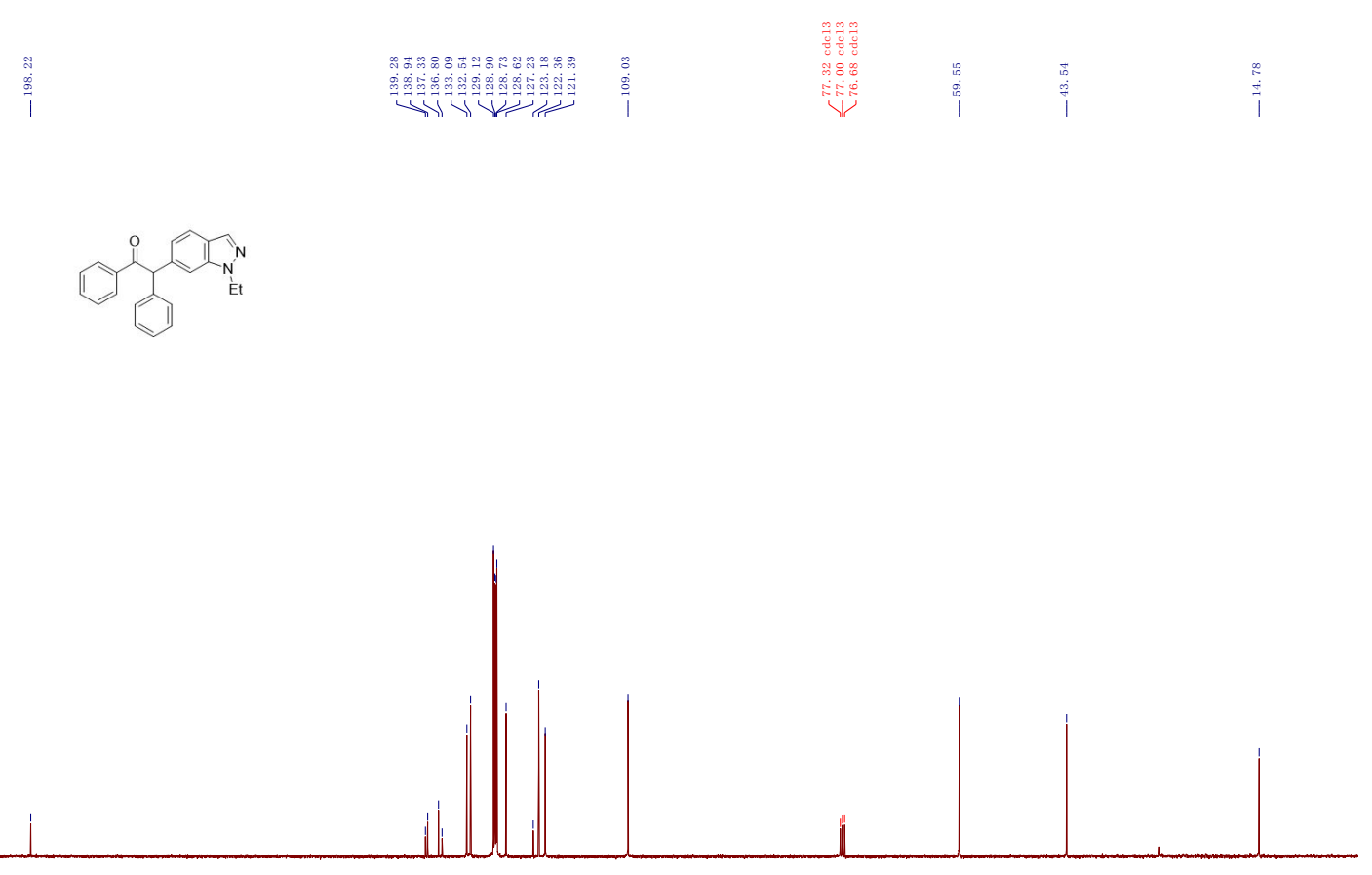

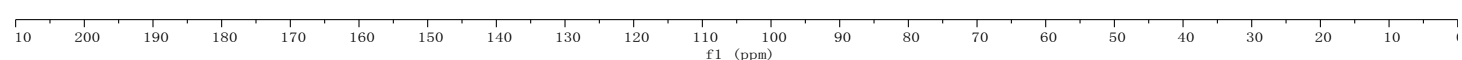


${ }^{\mathbf{1}} \mathbf{H}$ NMR spectrum of $\mathbf{5 a}$ in $\mathrm{CDCl}_{3}(400 \mathrm{MHz})$
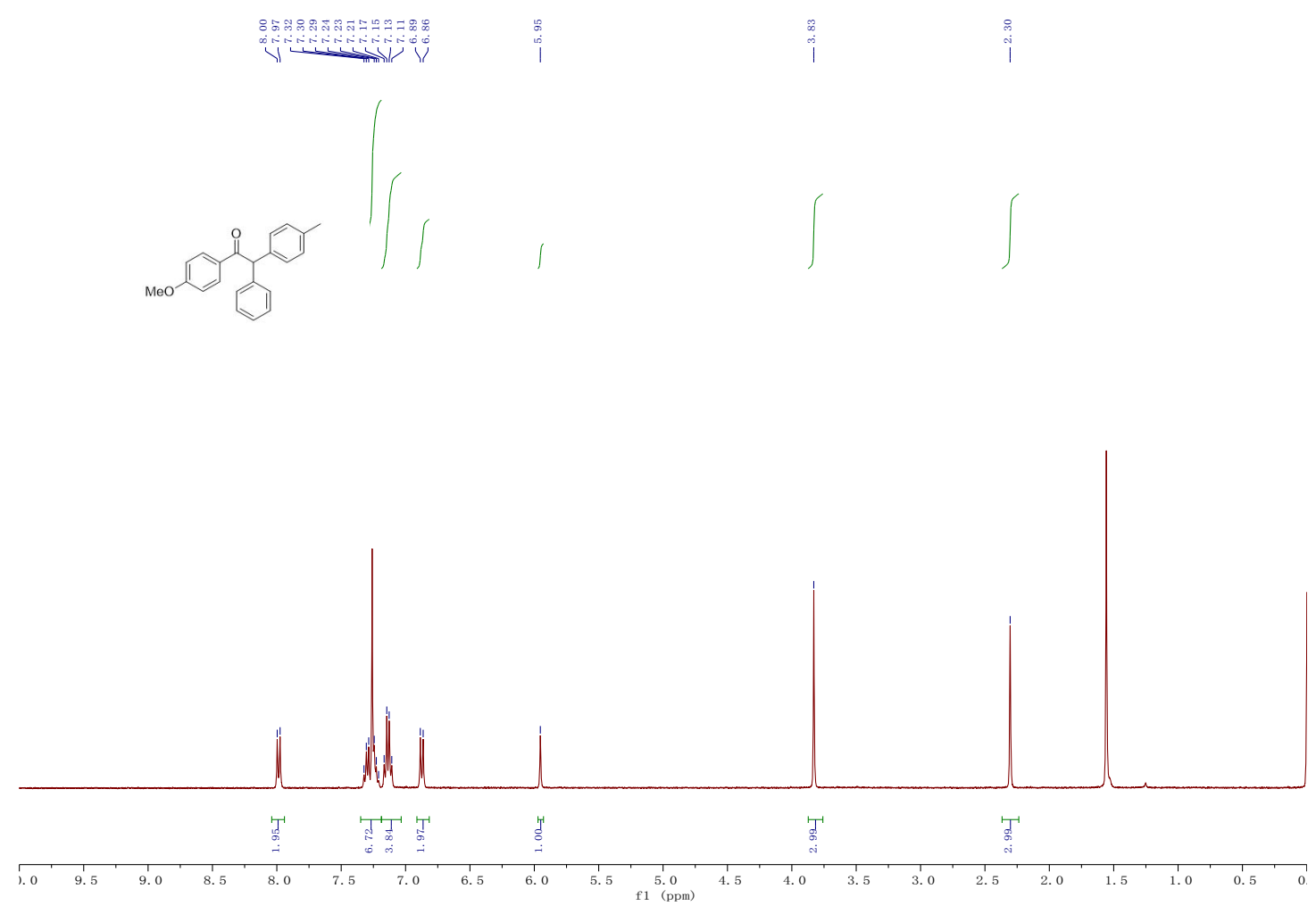

${ }^{13} \mathbf{C}$ NMR spectrum of $\mathbf{5 a}$ in $\mathrm{CDCl}_{3}(100 \mathrm{MHz})$

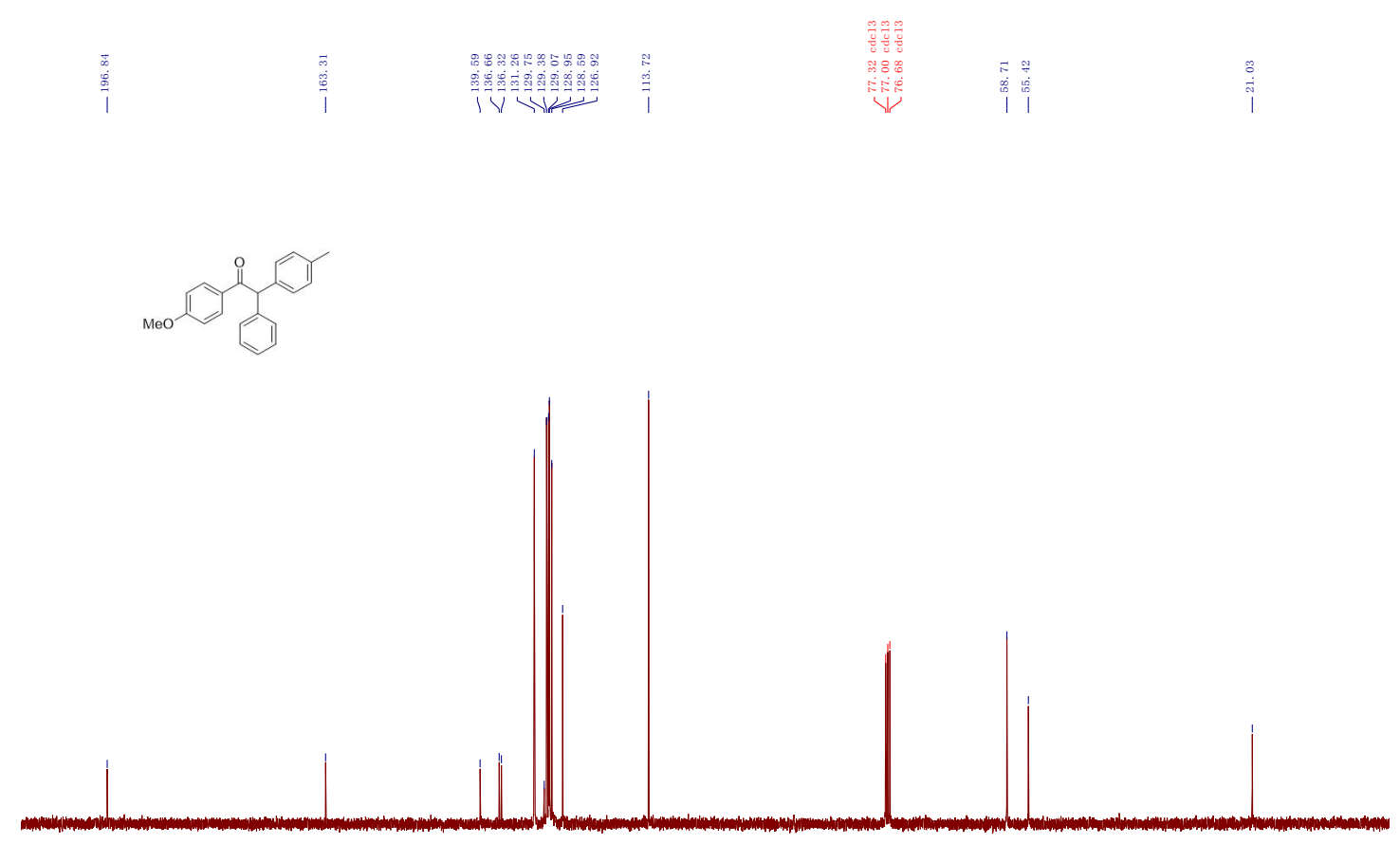

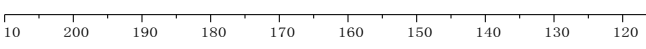

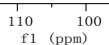


${ }^{\mathbf{1}} \mathbf{H}$ NMR spectrum of $\mathbf{5 b}$ in $\mathrm{CDCl}_{3}(400 \mathrm{MHz})$

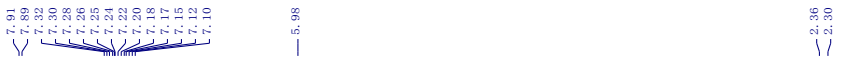
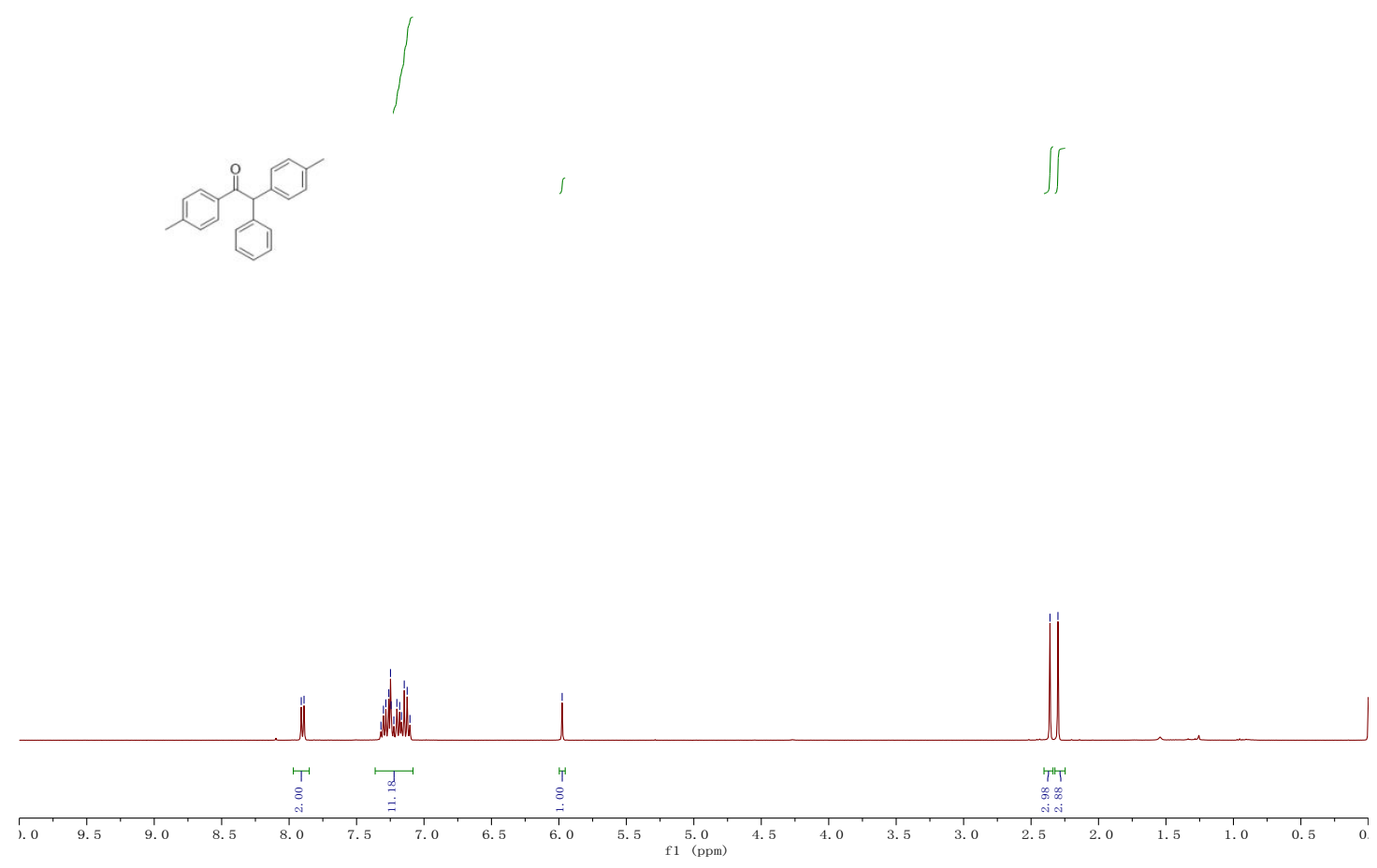

${ }^{13} \mathbf{C}$ NMR spectrum of $\mathbf{5 b}$ in $\mathrm{CDCl}_{3}(100 \mathrm{MHz})$

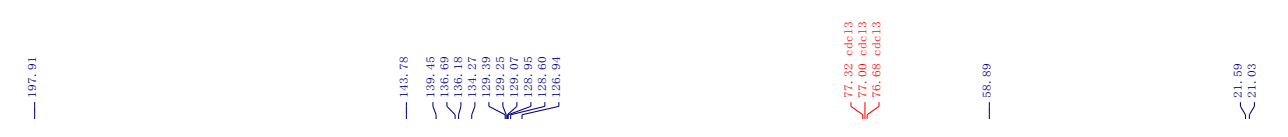

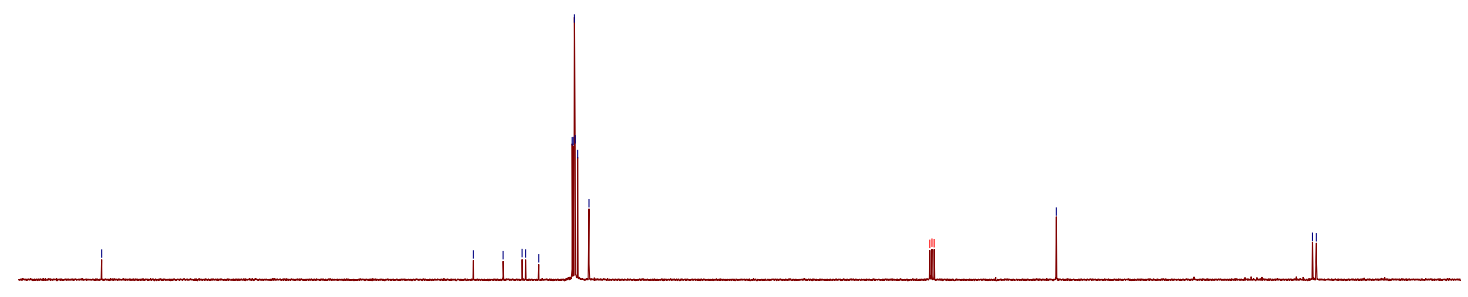

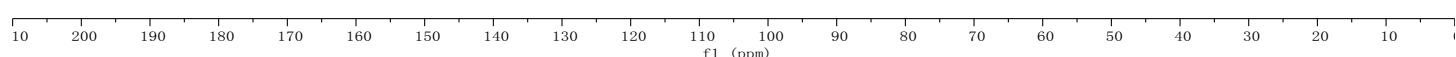


${ }^{1} \mathbf{H}$ NMR spectrum of $\mathbf{5 c}$ in $\mathrm{CDCl}_{3}(400 \mathrm{MHz})$
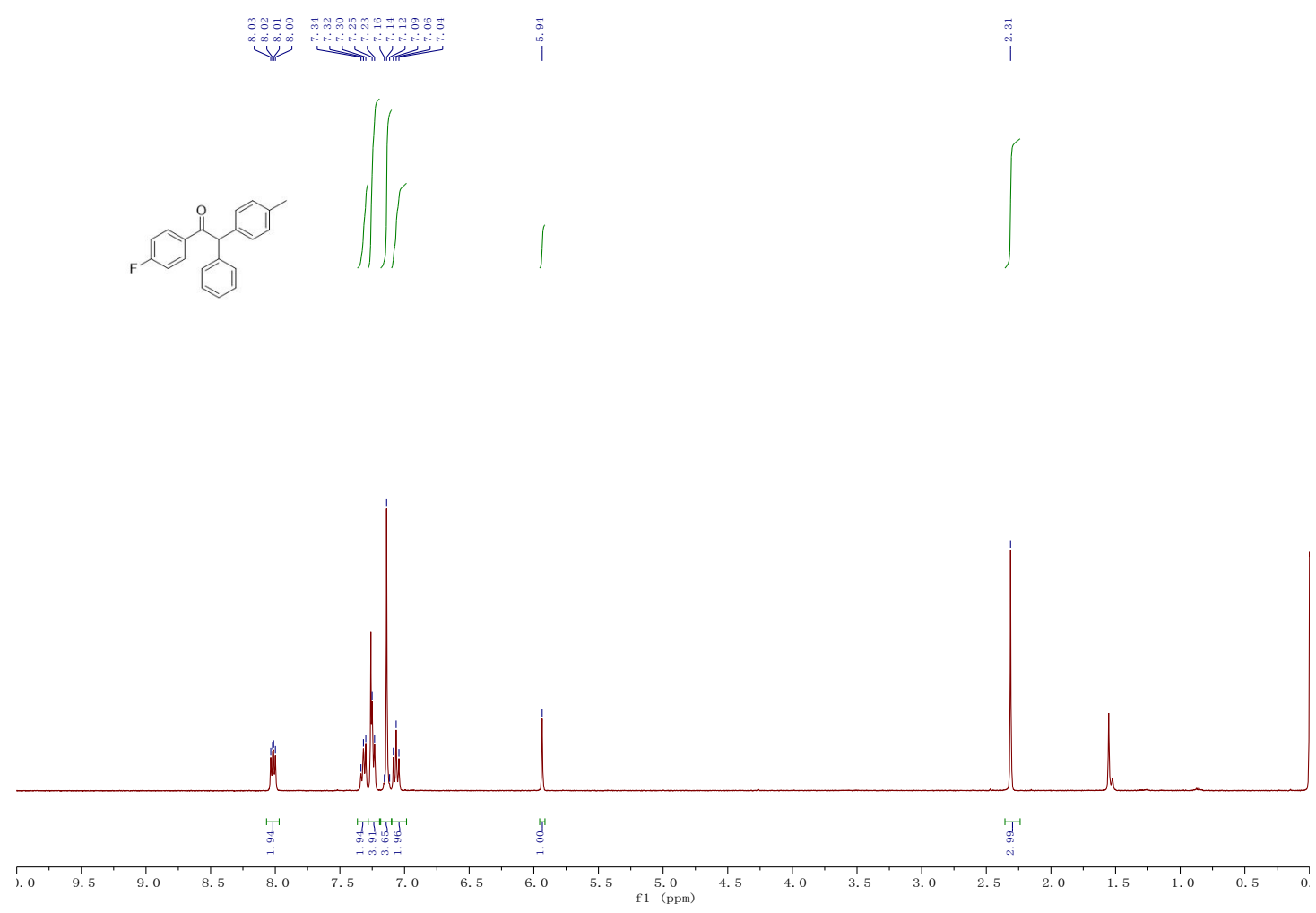

${ }^{13} \mathbf{C}$ NMR spectrum of $\mathbf{5 c}$ in $\mathrm{CDCl}_{3}(100 \mathrm{MHz})$

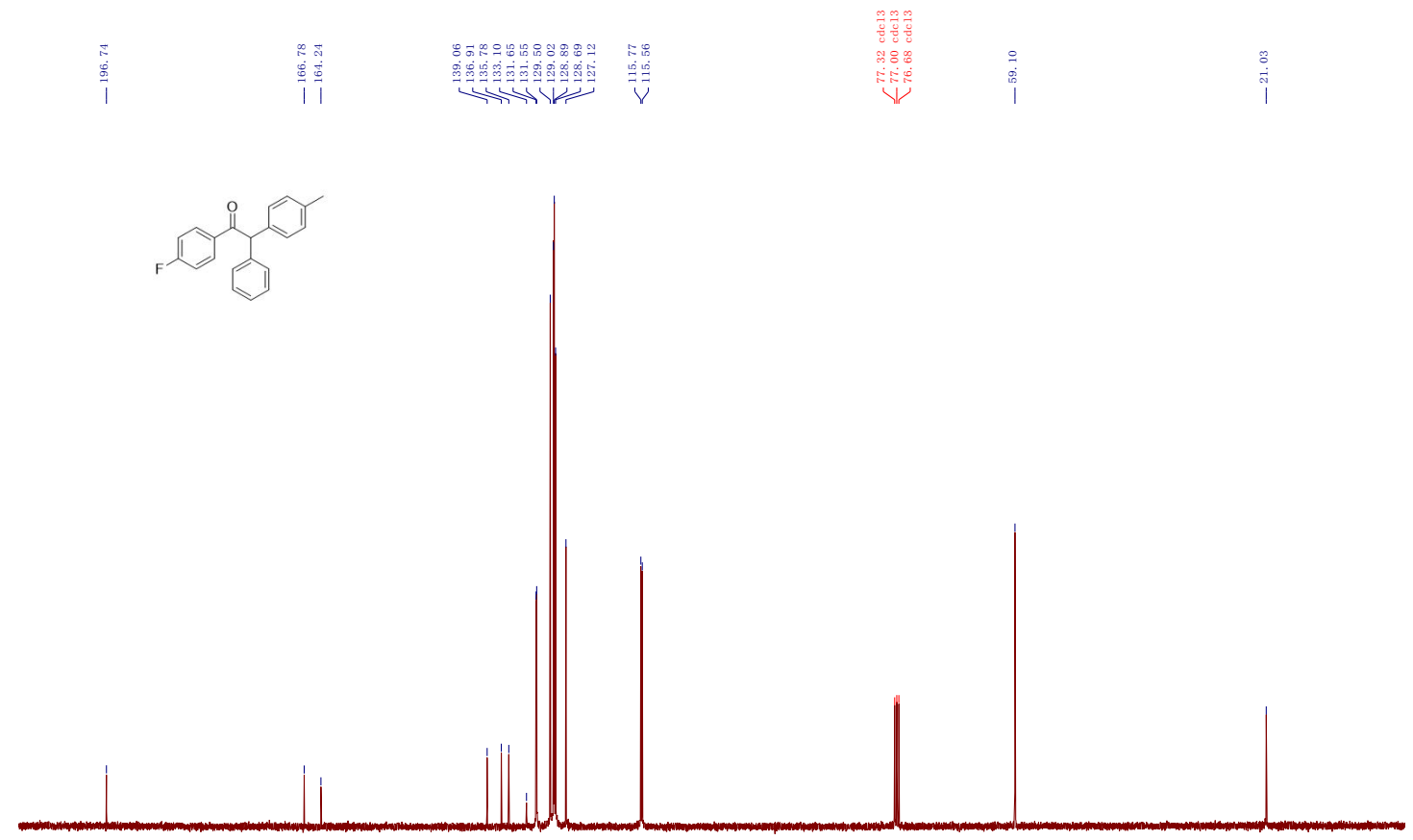

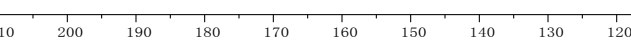


${ }^{19} \mathbf{F}$ NMR spectrum of $\mathbf{5 c}$ in $\mathrm{CDCl}_{3}(376 \mathrm{MHz})$

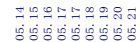

yisus
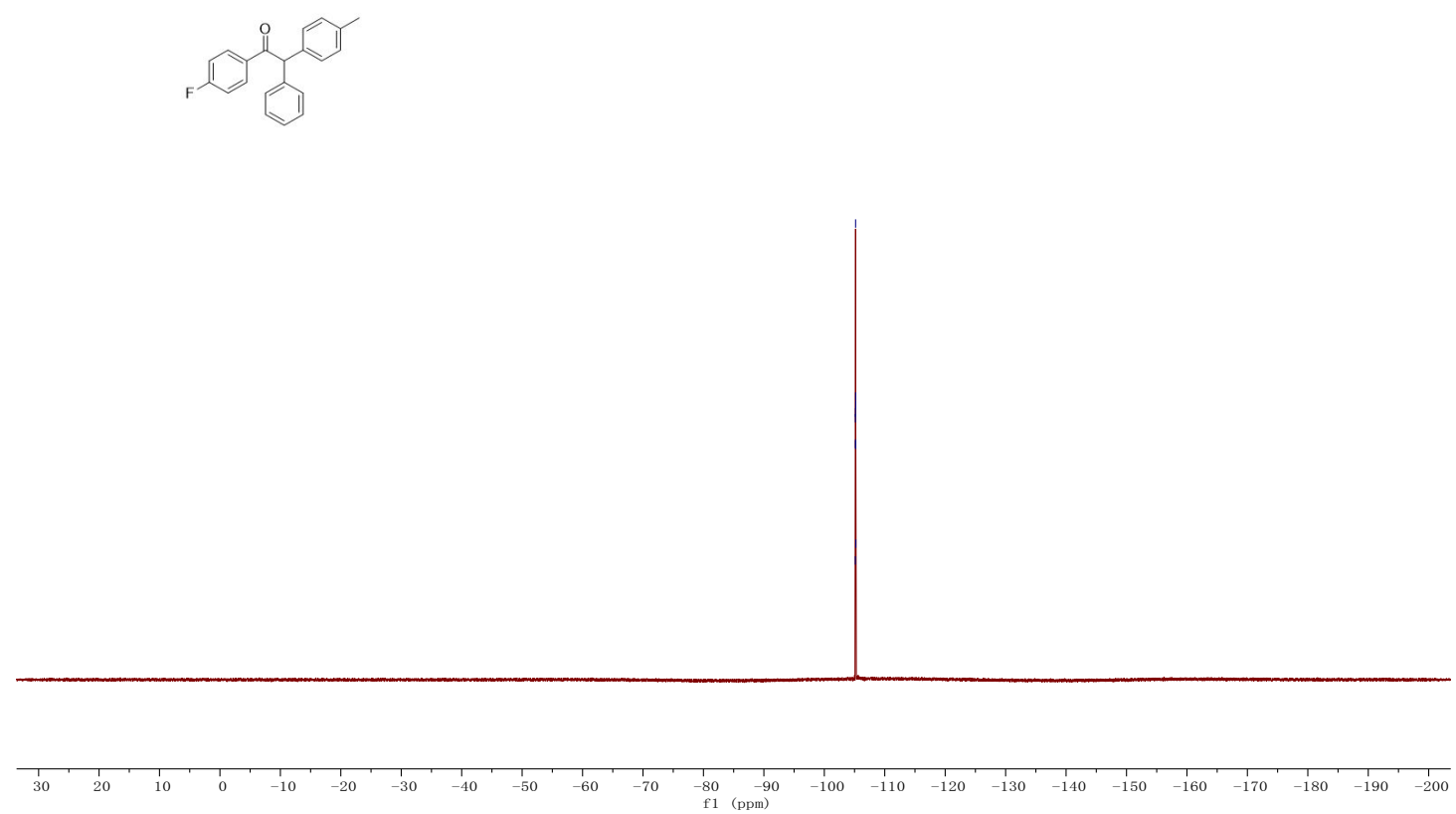

${ }^{1} \mathbf{H}$ NMR spectrum of $\mathbf{5 d}$ in $\mathrm{CDCl}_{3}(400 \mathrm{MHz})$

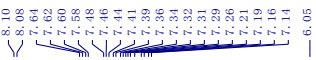
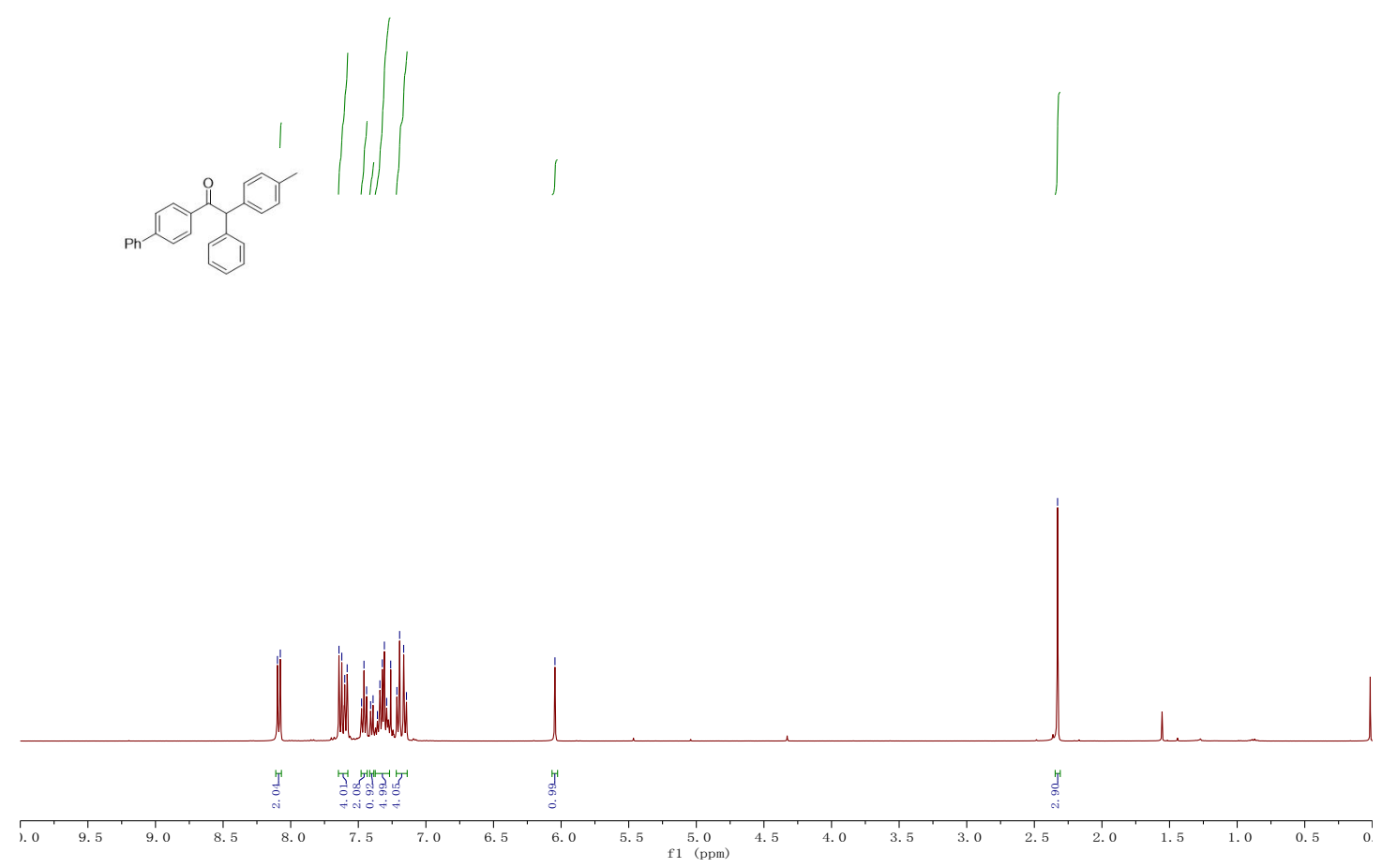
${ }^{13} \mathbf{C}$ NMR spectrum of $\mathbf{5 d}$ in $\mathrm{CDCl}_{3}(100 \mathrm{MHz})$

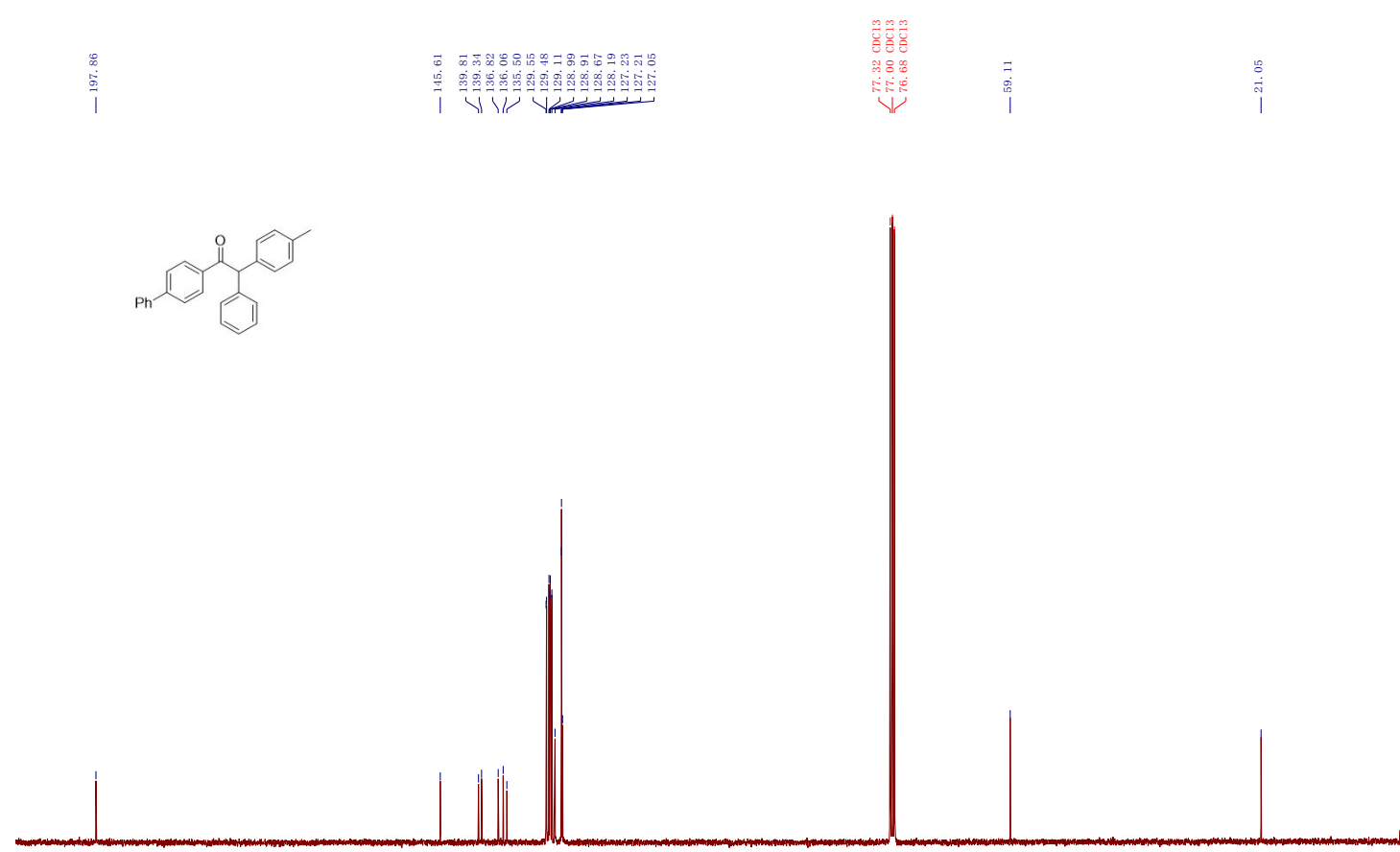

${ }^{1} \mathbf{H}$ NMR spectrum of $5 \mathbf{e}$ in $\mathrm{CDCl}_{3}(400 \mathrm{MHz})$

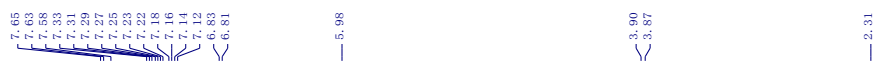
(1)

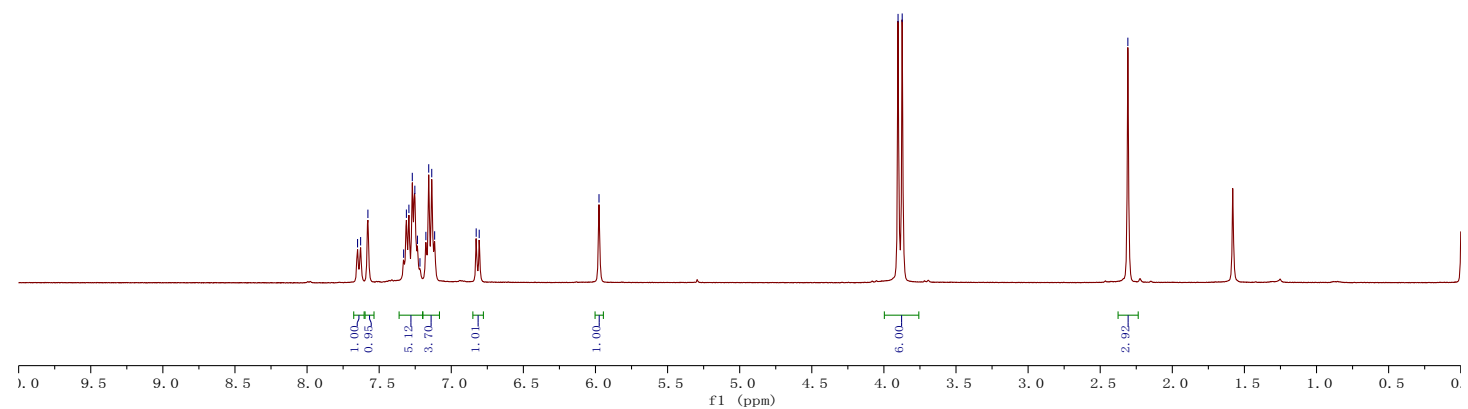


${ }^{13} \mathbf{C}$ NMR spectrum of $\mathbf{5 e}$ in $\mathrm{CDCl}_{3}(100 \mathrm{MHz})$

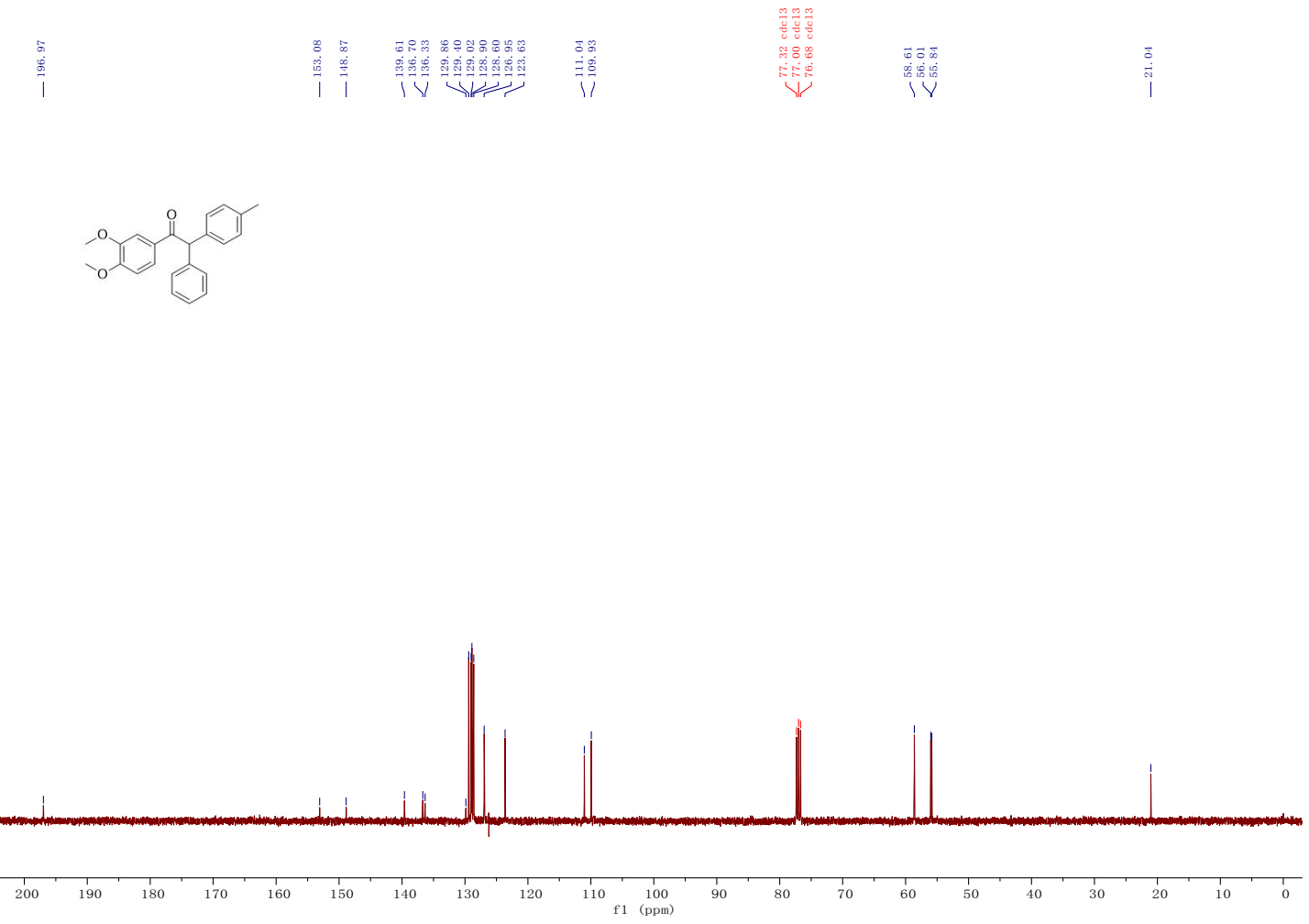

${ }^{1} \mathbf{H}$ NMR spectrum of $\mathbf{5 f}$ in $\mathrm{CDCl}_{3}(400 \mathrm{MHz})$
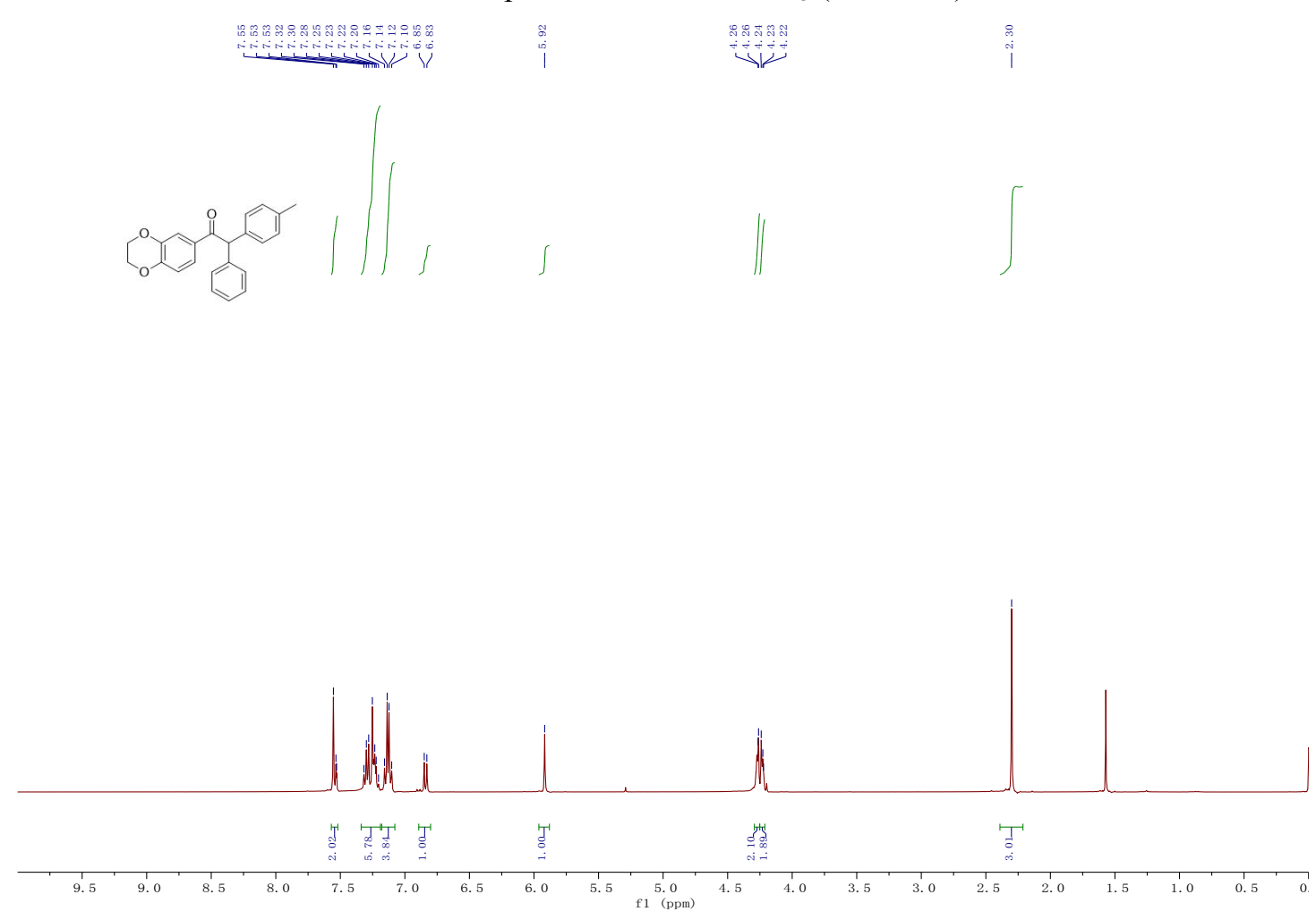
${ }^{13} \mathbf{C}$ NMR spectrum of $\mathbf{5 f}$ in $\mathrm{CDCl}_{3}(100 \mathrm{MHz})$

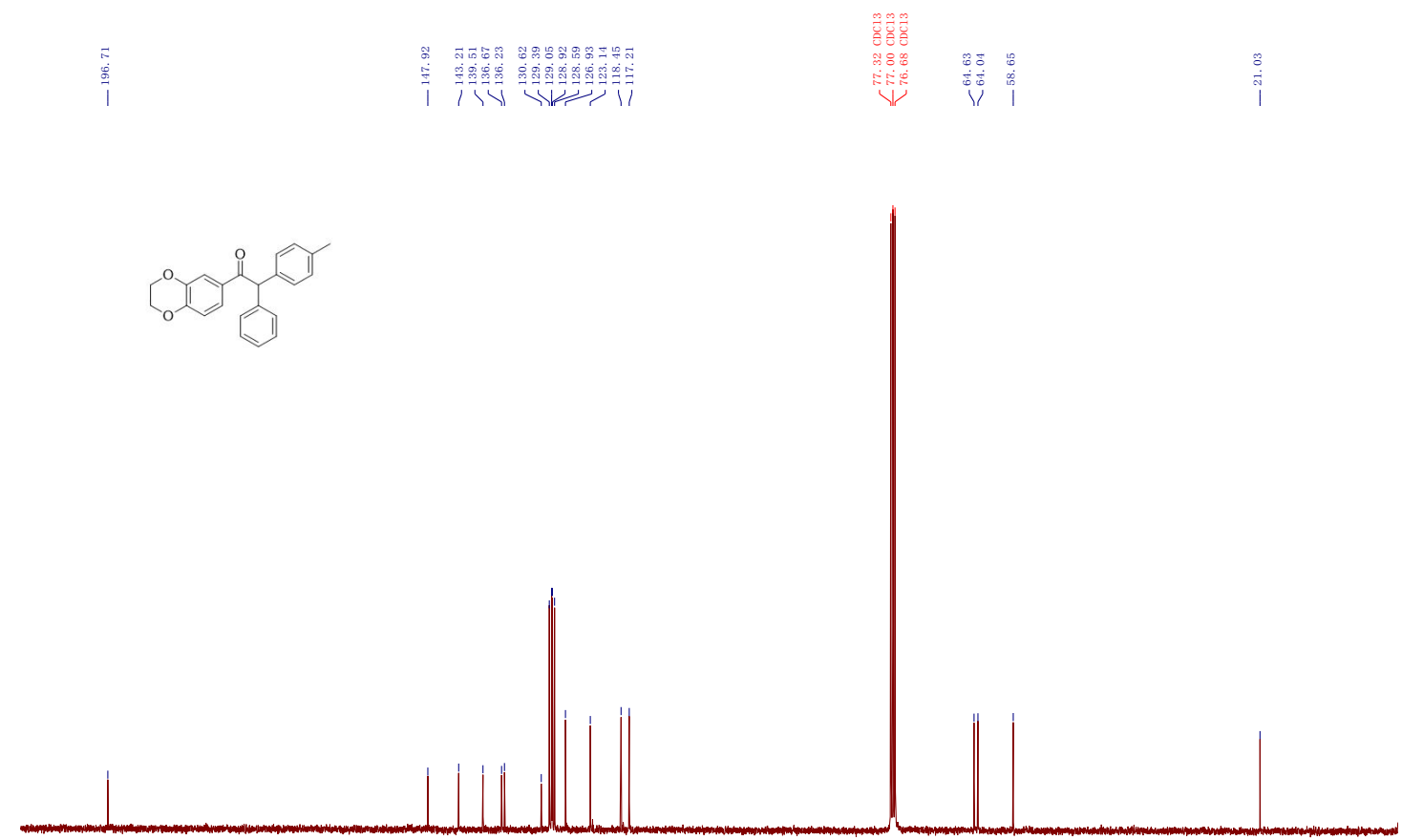

${ }^{\mathbf{1}} \mathbf{H}$ NMR spectrum of $\mathbf{5 g}$ in $\mathrm{CDCl}_{3}(400 \mathrm{MHz})$
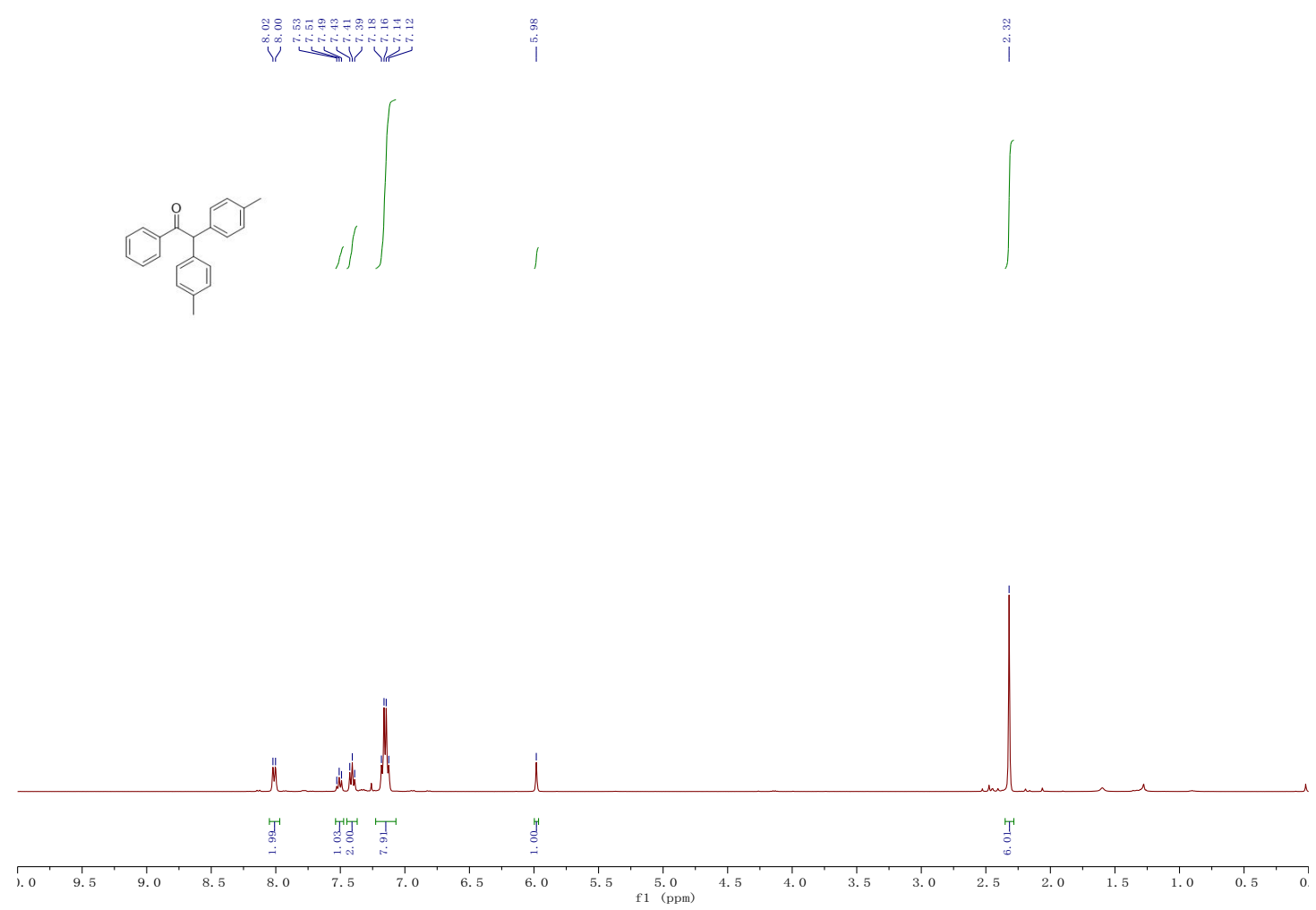
${ }^{13} \mathbf{C}$ NMR spectrum of $\mathbf{5 g}$ in $\mathrm{CDCl}_{3}(100 \mathrm{MHz})$

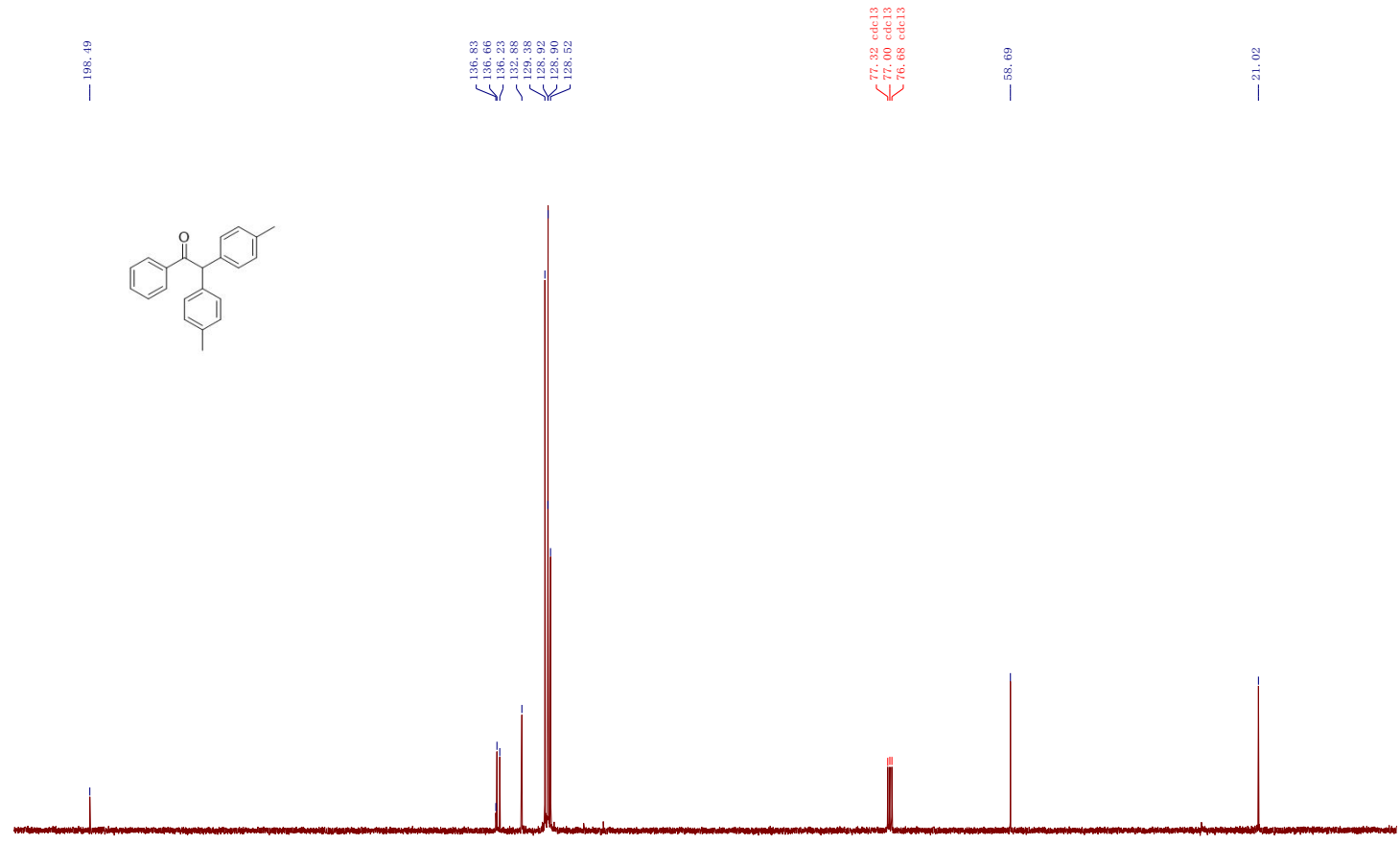

${ }^{\mathbf{1}} \mathbf{H}$ NMR spectrum of $\mathbf{5 h}$ in $\mathrm{CDCl}_{3}(400 \mathrm{MHz})$
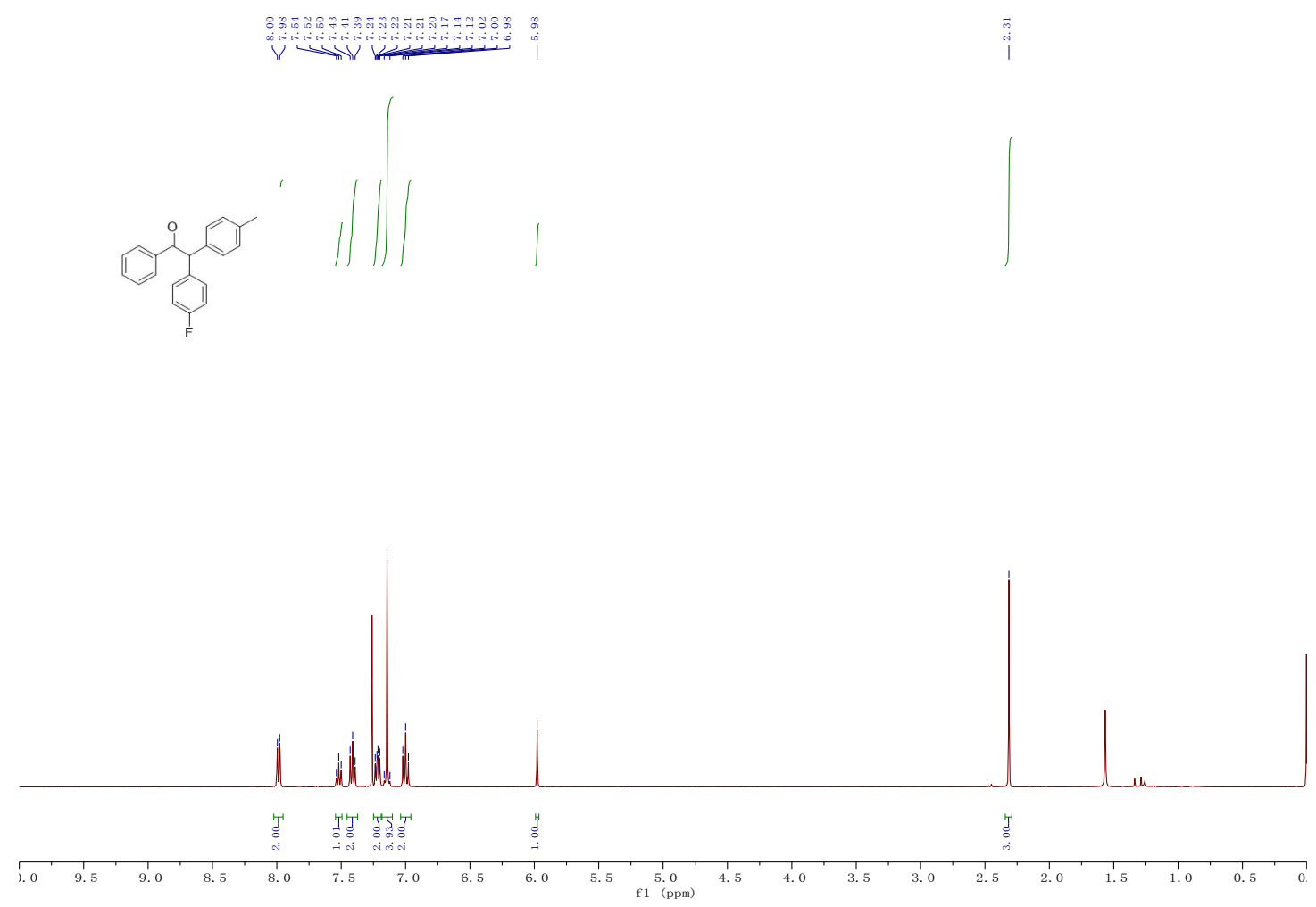
${ }^{13} \mathbf{C}$ NMR spectrum of $\mathbf{5 h}$ in $\mathrm{CDCl}_{3}(100 \mathrm{MHz})$

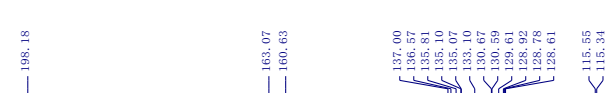
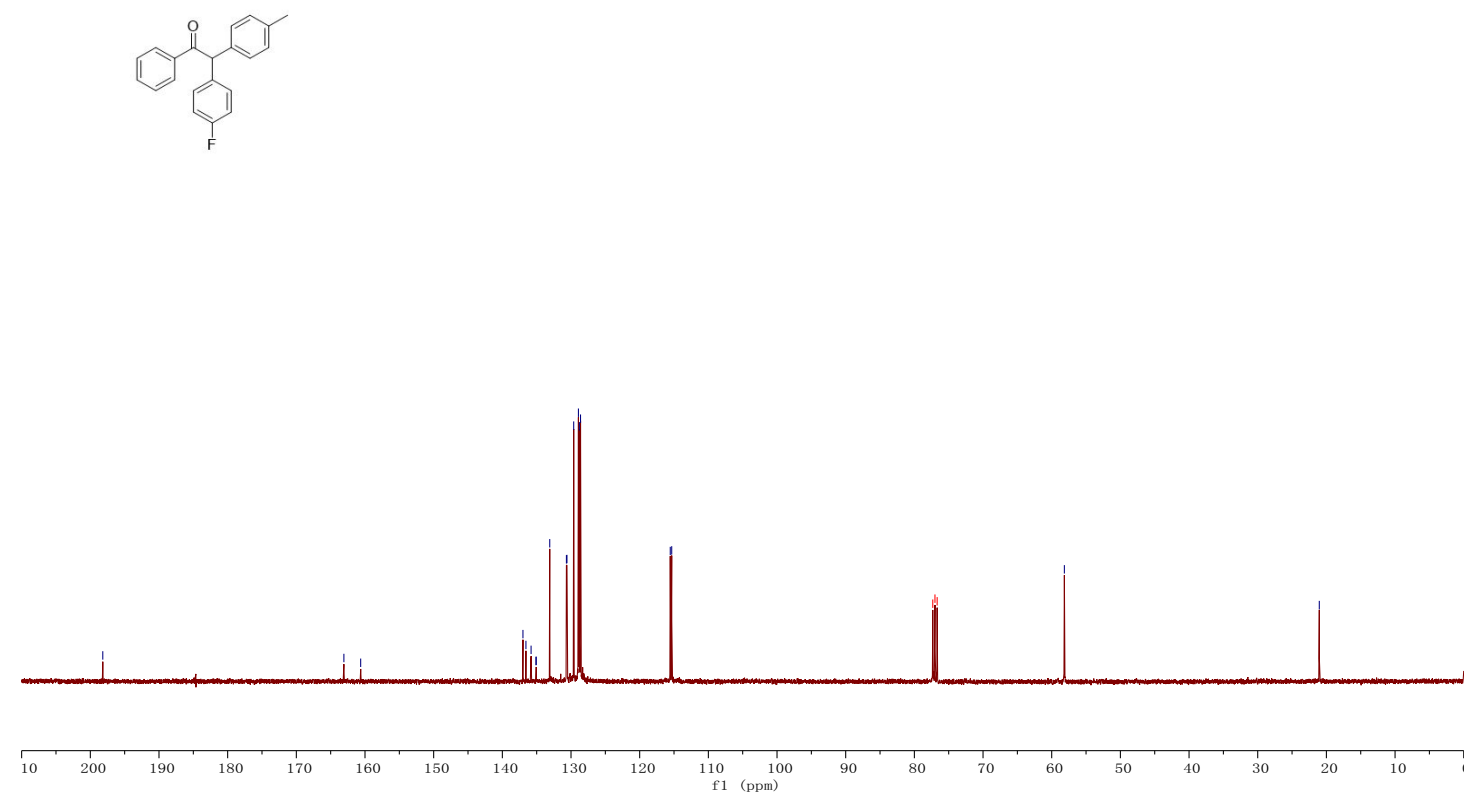

${ }^{19} \mathbf{F}$ NMR spectrum of $\mathbf{5 h}$ in $\mathrm{CDCl}_{3}(376 \mathrm{MHz})$

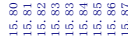

近
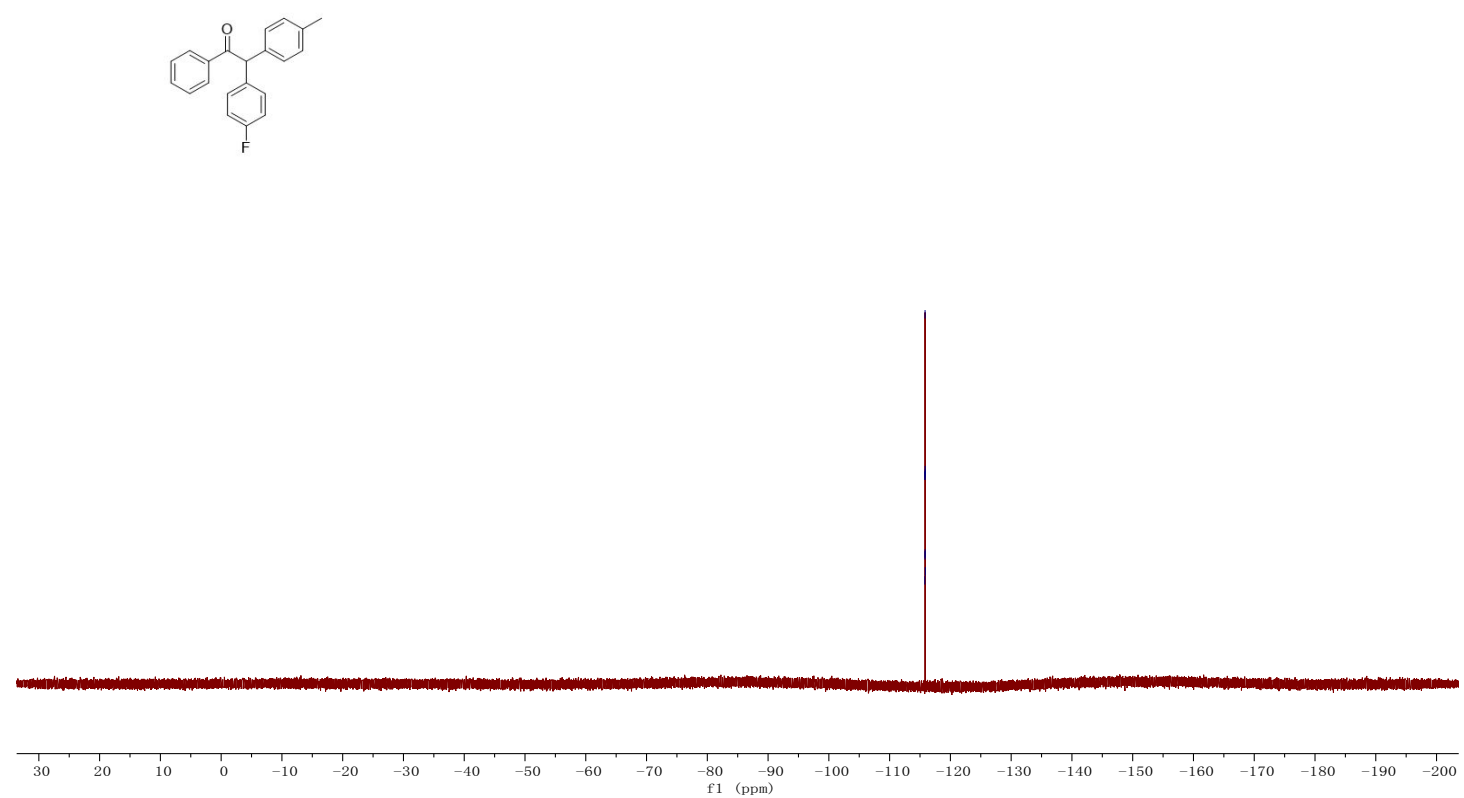


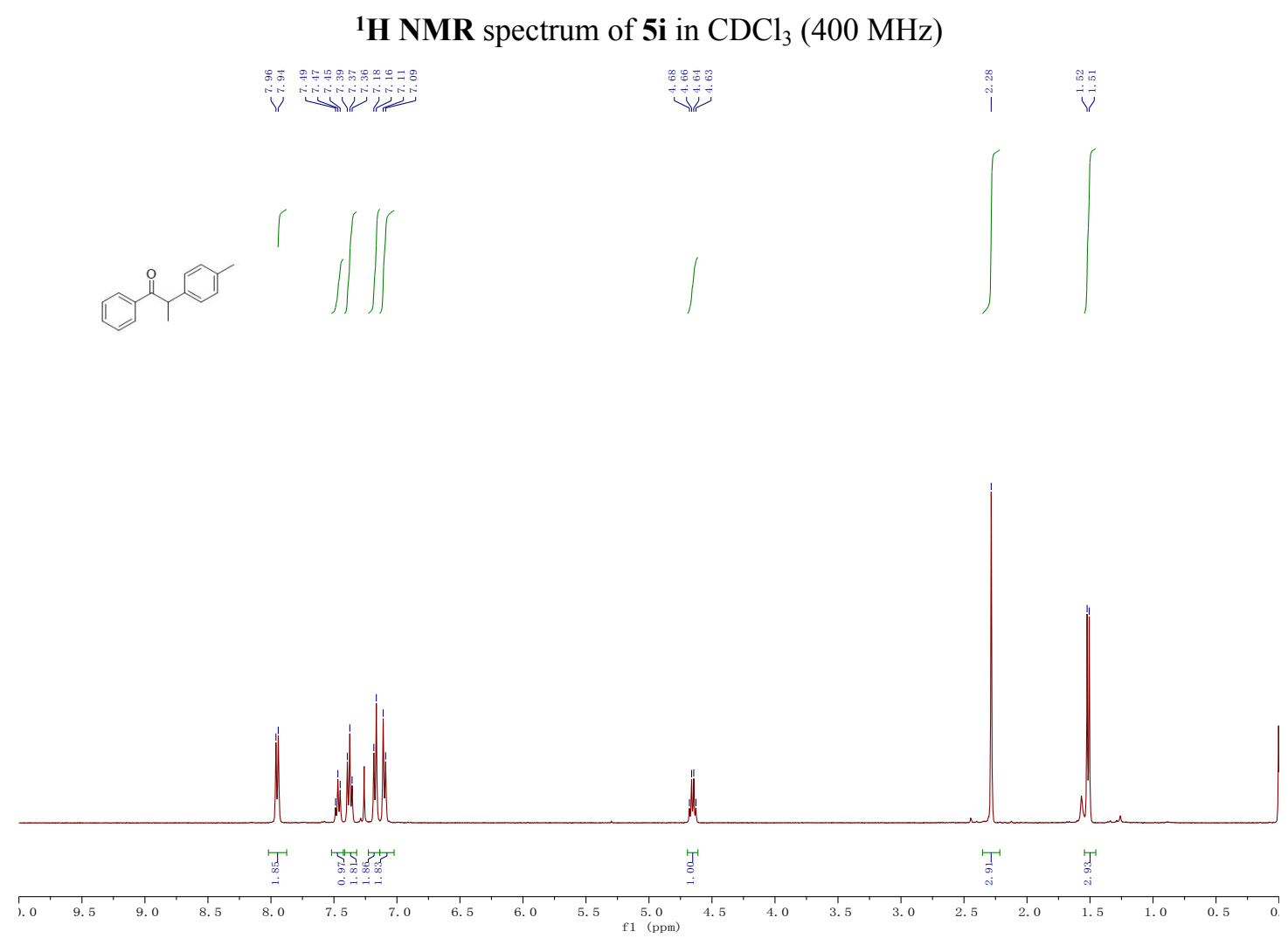

${ }^{13} \mathbf{C}$ NMR spectrum of $\mathbf{5 i}$ in $\mathrm{CDCl}_{3}(100 \mathrm{MHz})$

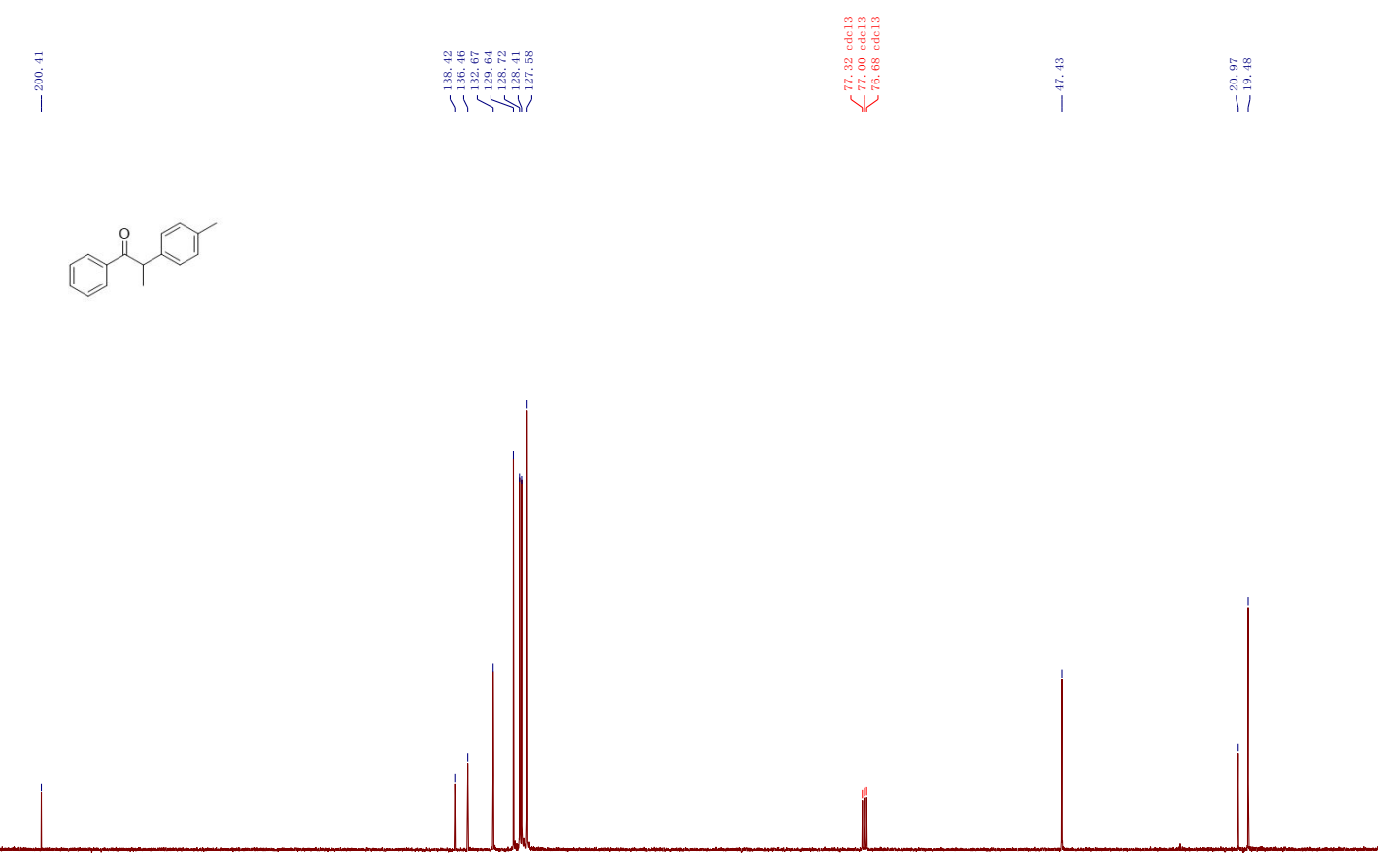

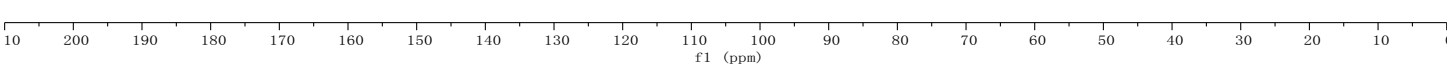


${ }^{\mathbf{1}} \mathbf{H}$ NMR spectrum of $\mathbf{5 j}$ in $\mathrm{CDCl}_{3}(400 \mathrm{MHz})$
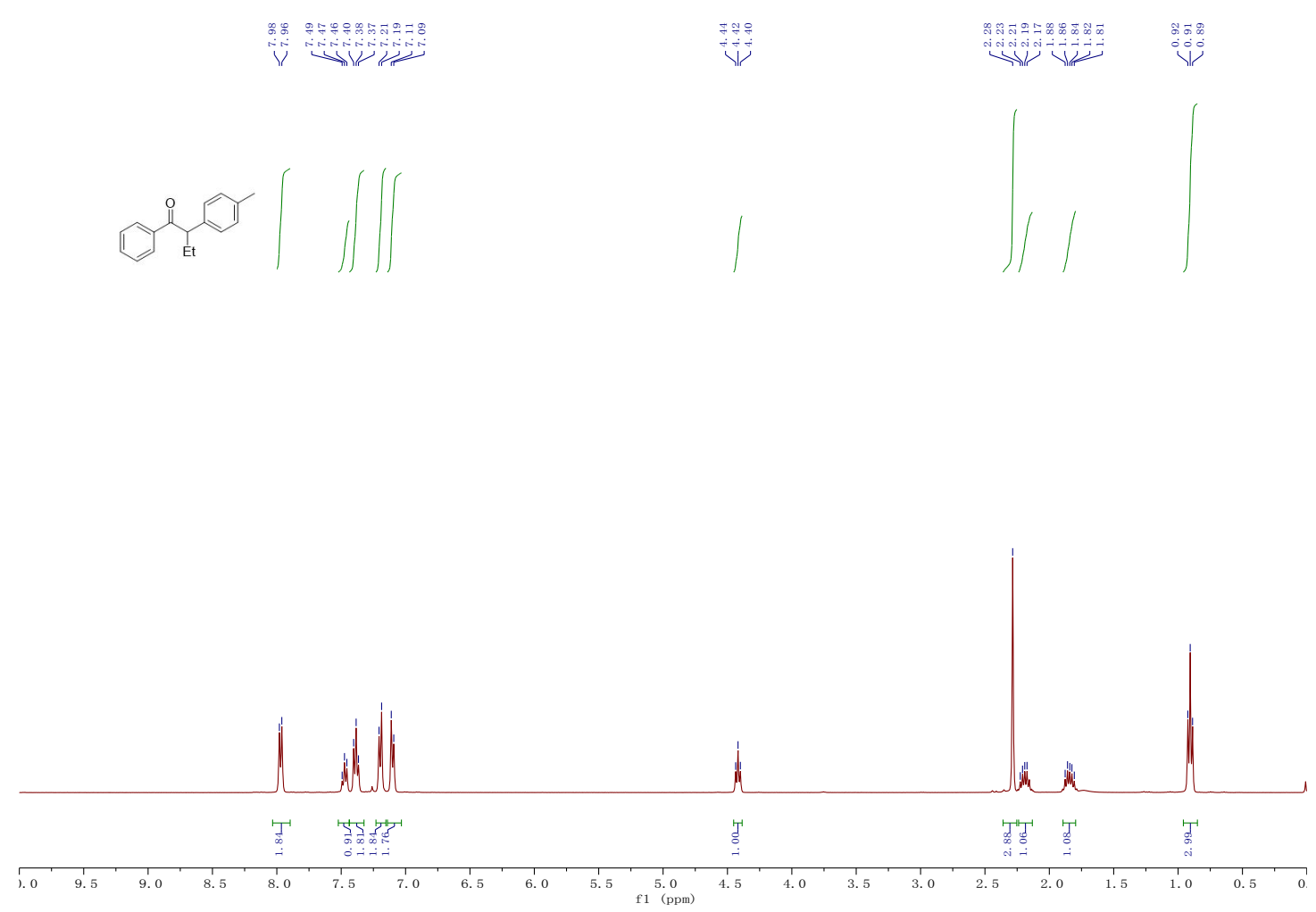

${ }^{13} \mathbf{C}$ NMR spectrum of $\mathbf{5 j}$ in $\mathrm{CDCl}_{3}(100 \mathrm{MHz})$

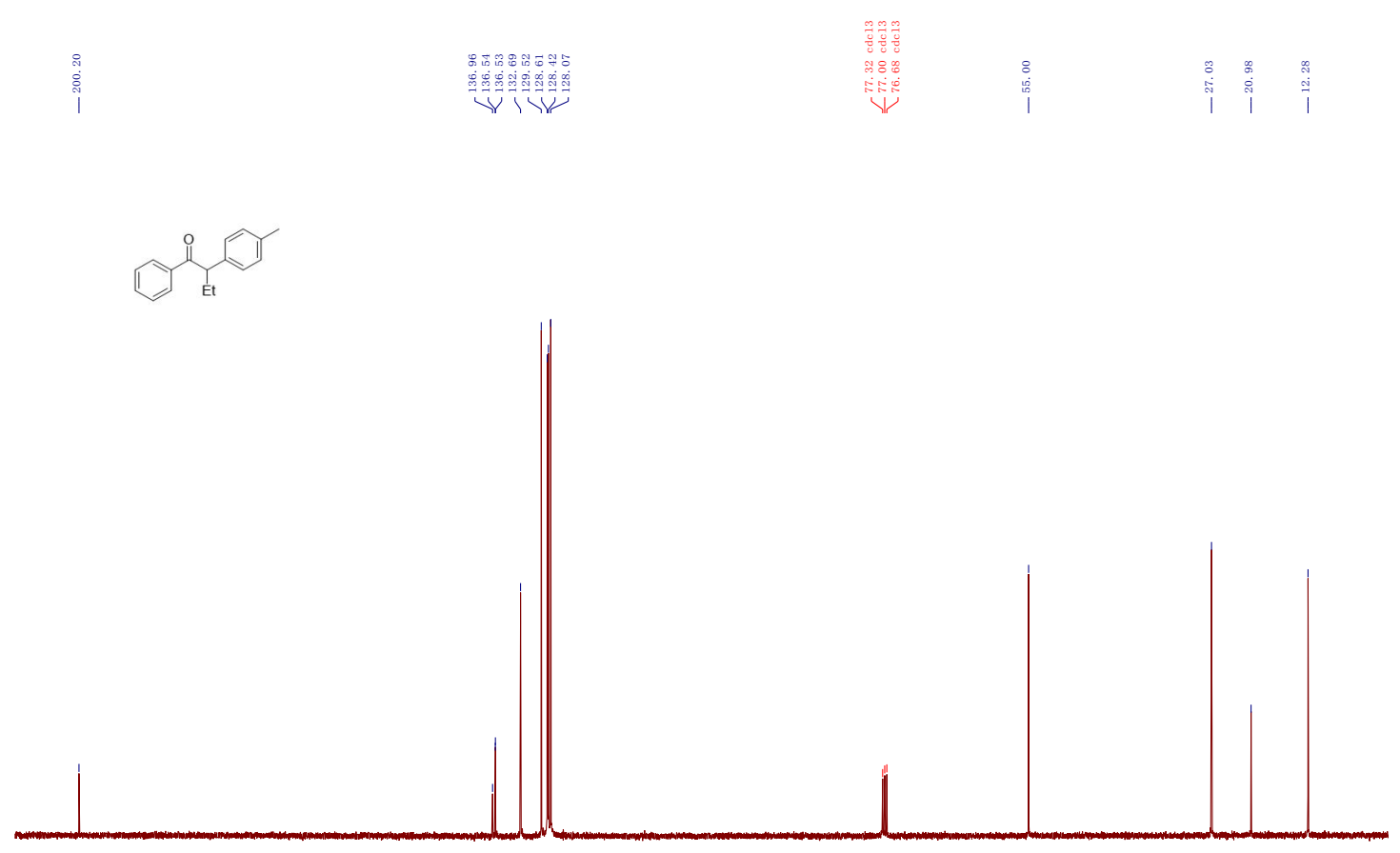

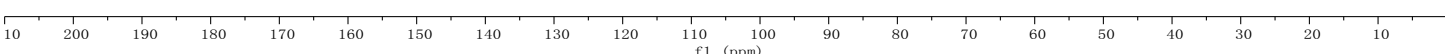


${ }^{\mathbf{1}} \mathbf{H}$ NMR spectrum of $\mathbf{5 k}$ in $\mathrm{CDCl}_{3}(400 \mathrm{MHz})$

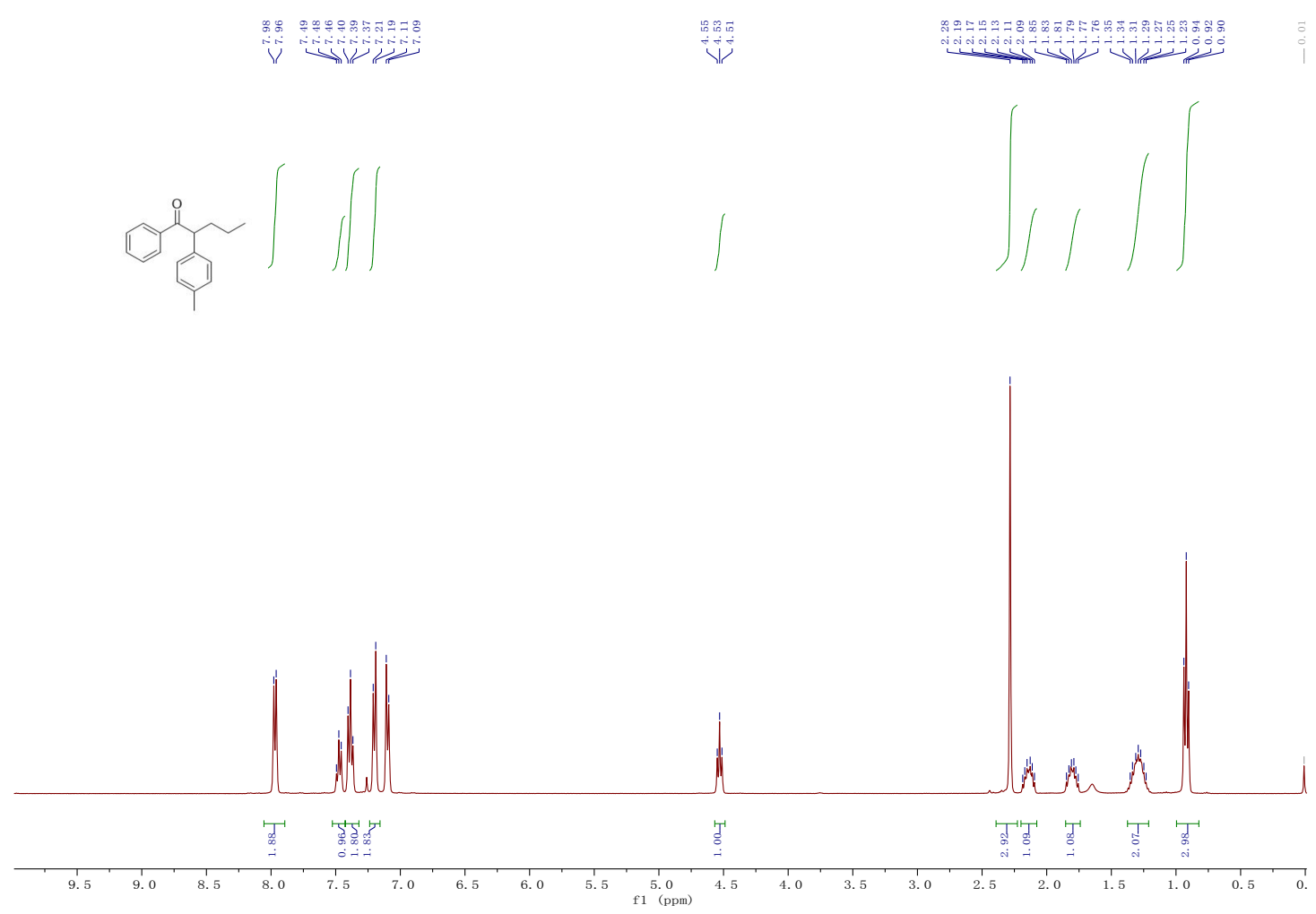

${ }^{13} \mathbf{C}$ NMR spectrum of $\mathbf{5 k}$ in $\mathrm{CDCl}_{3}(100 \mathrm{MHz})$

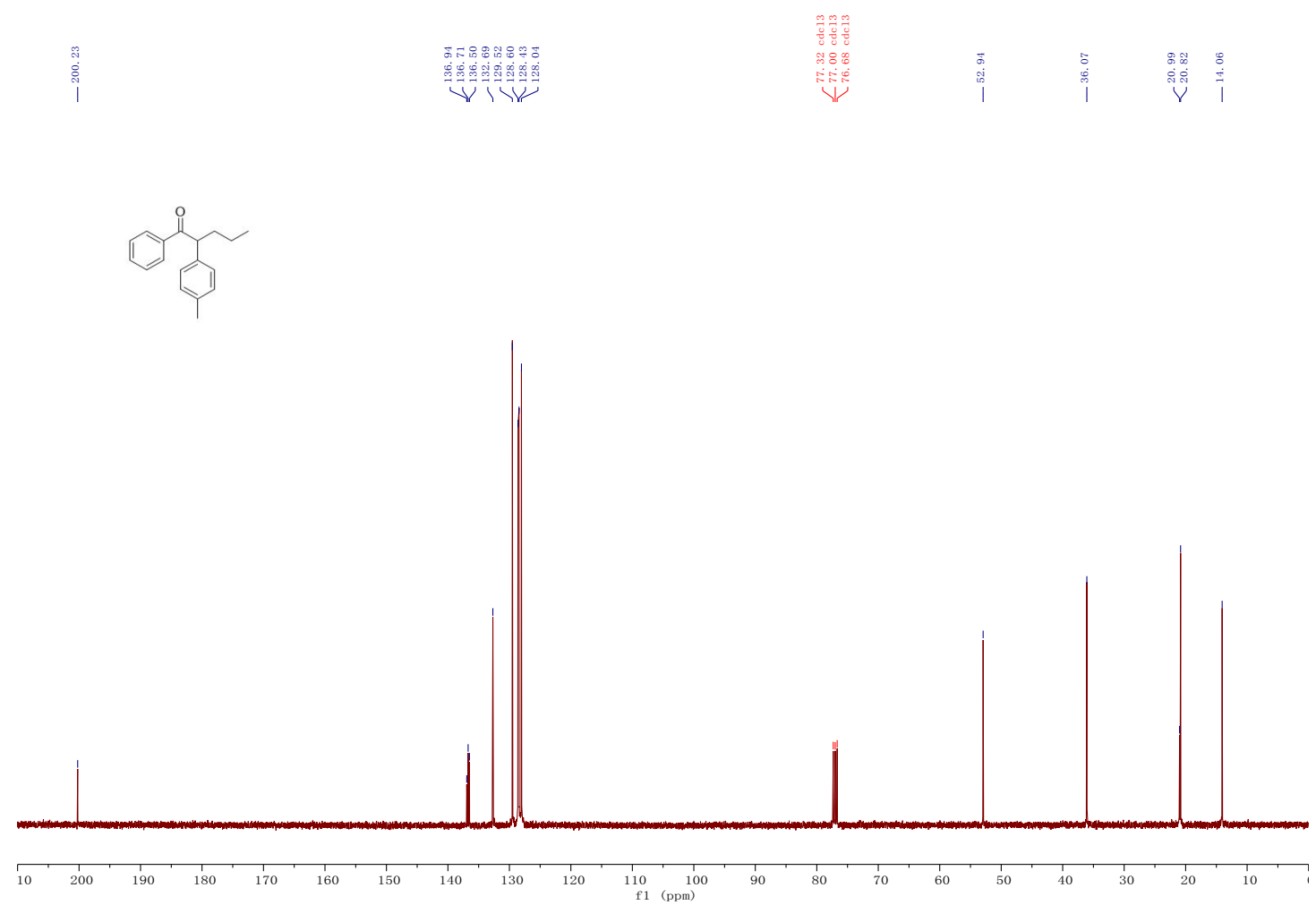


${ }^{\mathbf{1}} \mathbf{H}$ NMR spectrum of $\mathbf{5 l}$ in $\mathrm{CDCl}_{3}(400 \mathrm{MHz})$
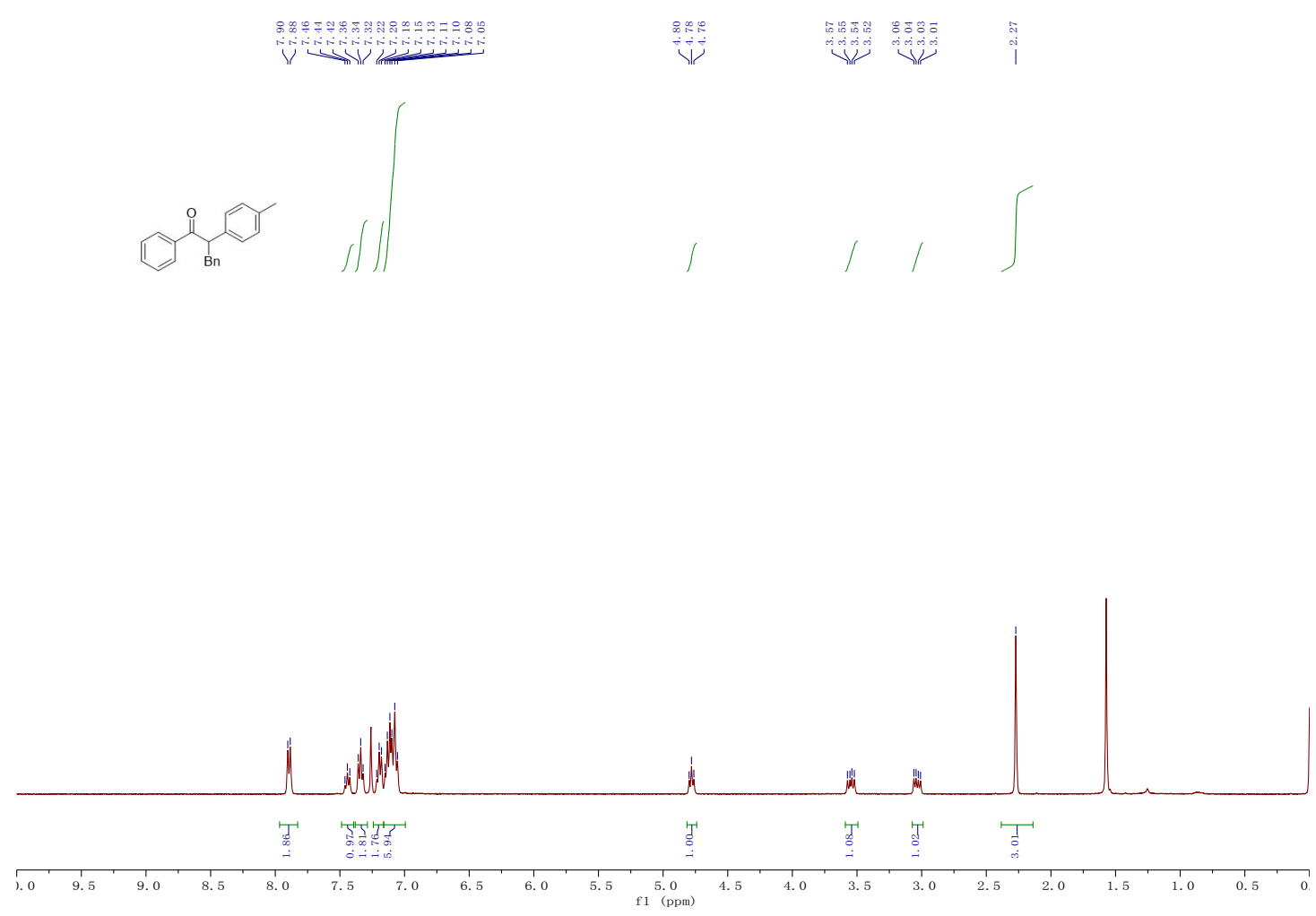

${ }^{13} \mathbf{C}$ NMR spectrum of $\mathbf{5 l}$ in $\mathrm{CDCl}_{3}(100 \mathrm{MHz})$
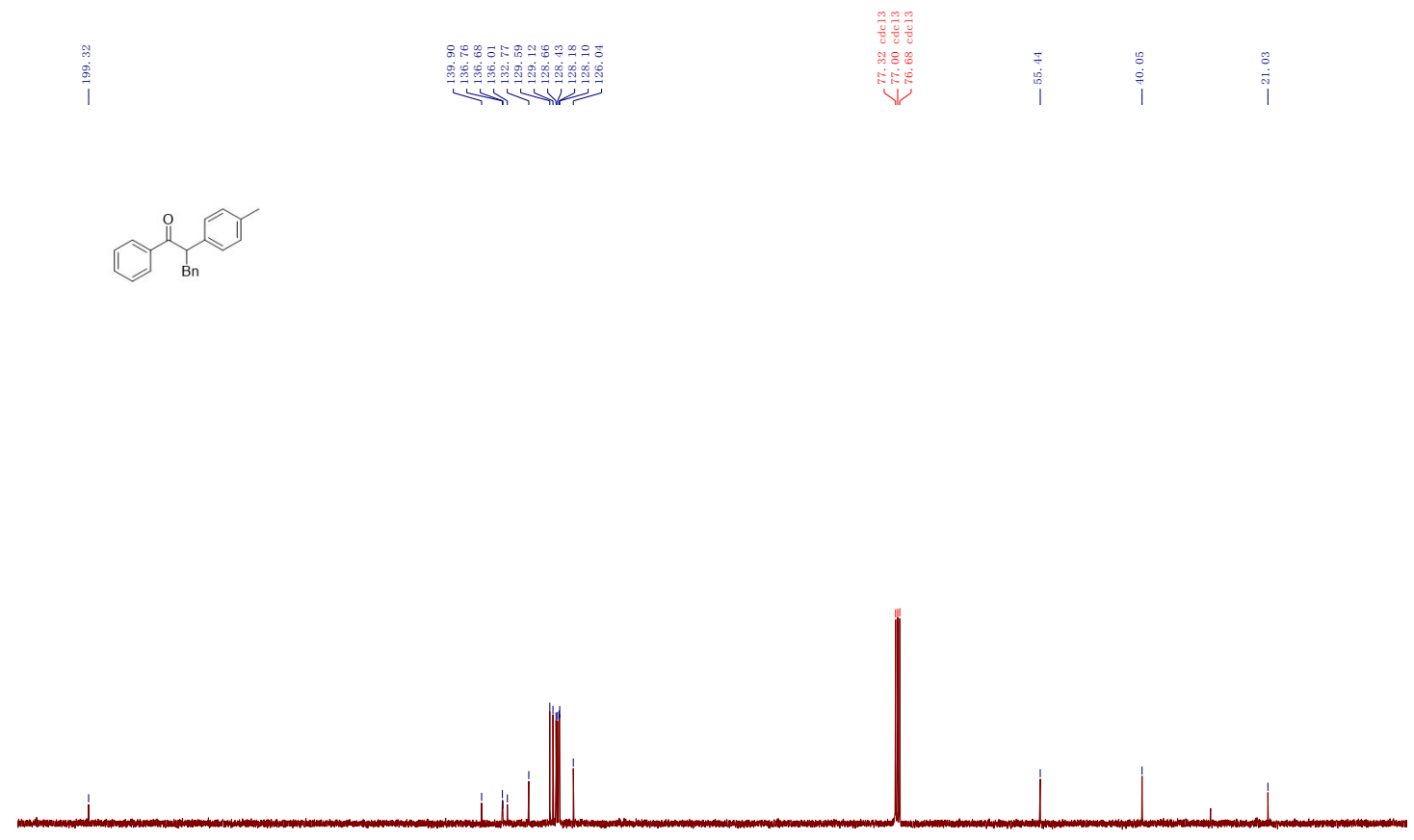
${ }^{1} \mathbf{H}$ NMR spectrum of 8 in $\mathrm{CDCl}_{3}(400 \mathrm{MHz})$

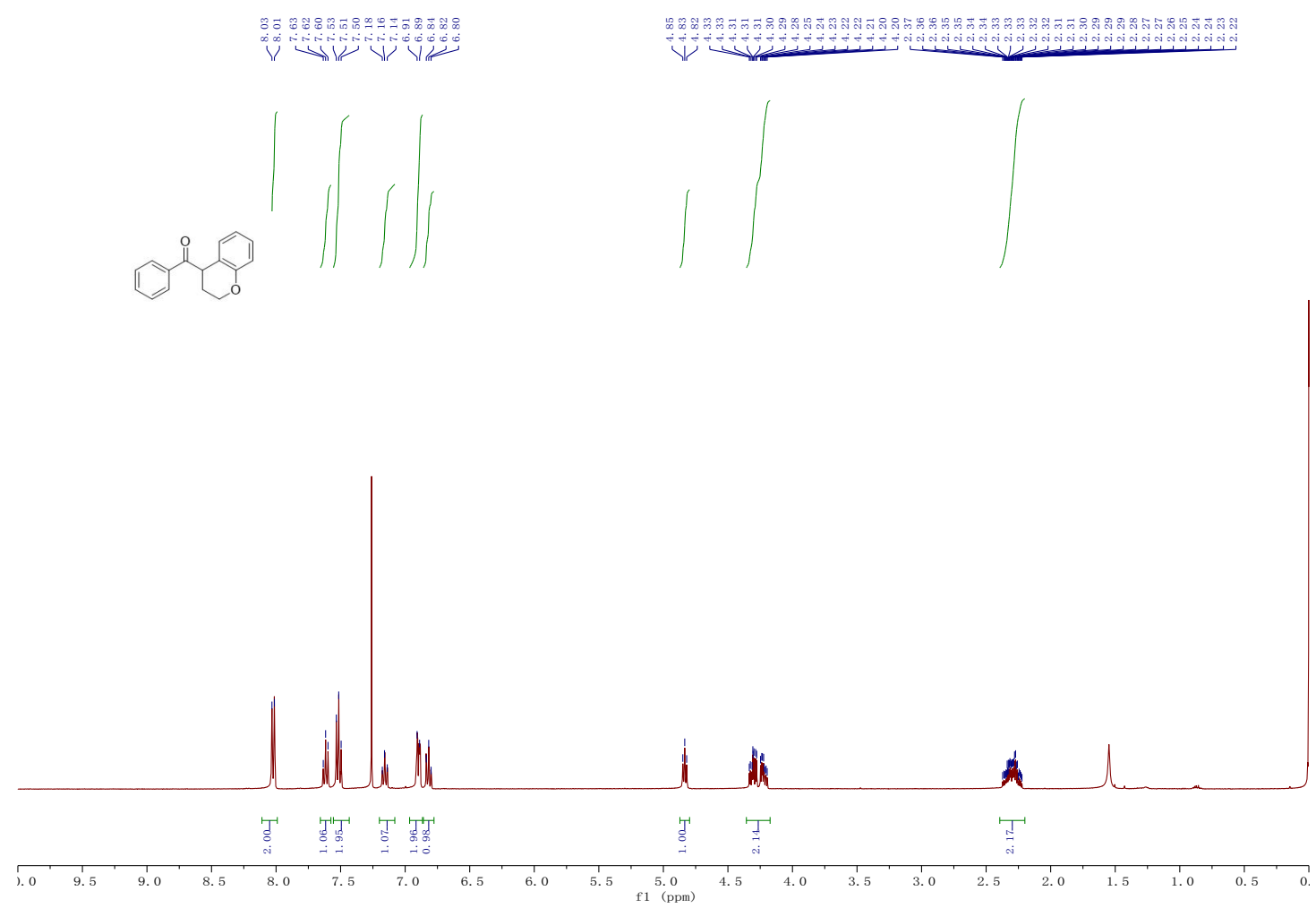

${ }^{13} \mathbf{C}$ NMR spectrum of 8 in $\mathrm{CDCl}_{3}(100 \mathrm{MHz})$

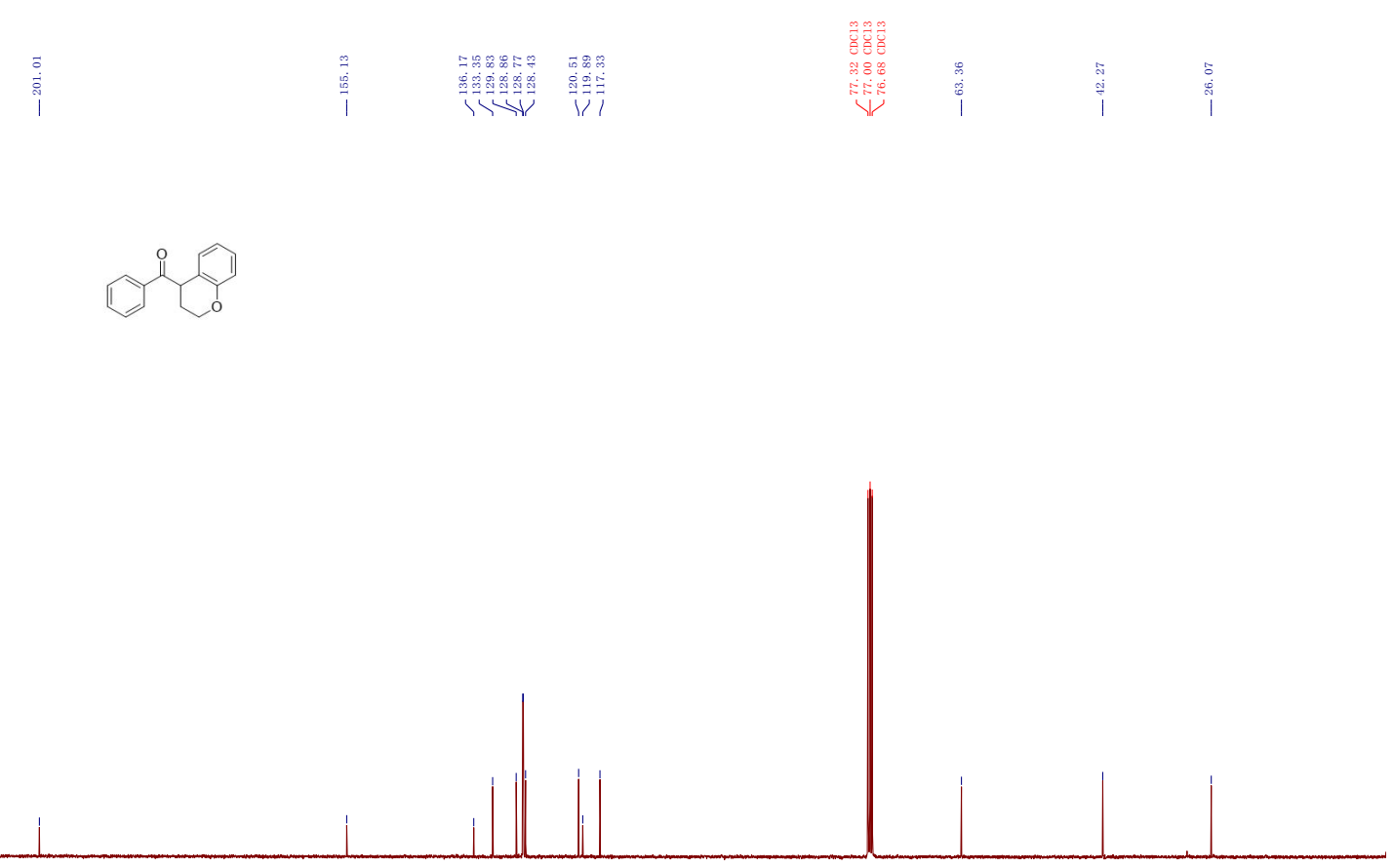

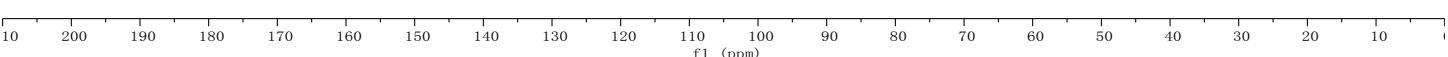


${ }^{1} \mathrm{H}$ NMR spectrum of $\mathbf{1 0}$ in $\mathrm{CDCl}_{3}(400 \mathrm{MHz})$

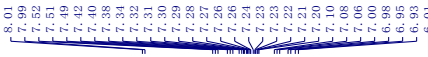
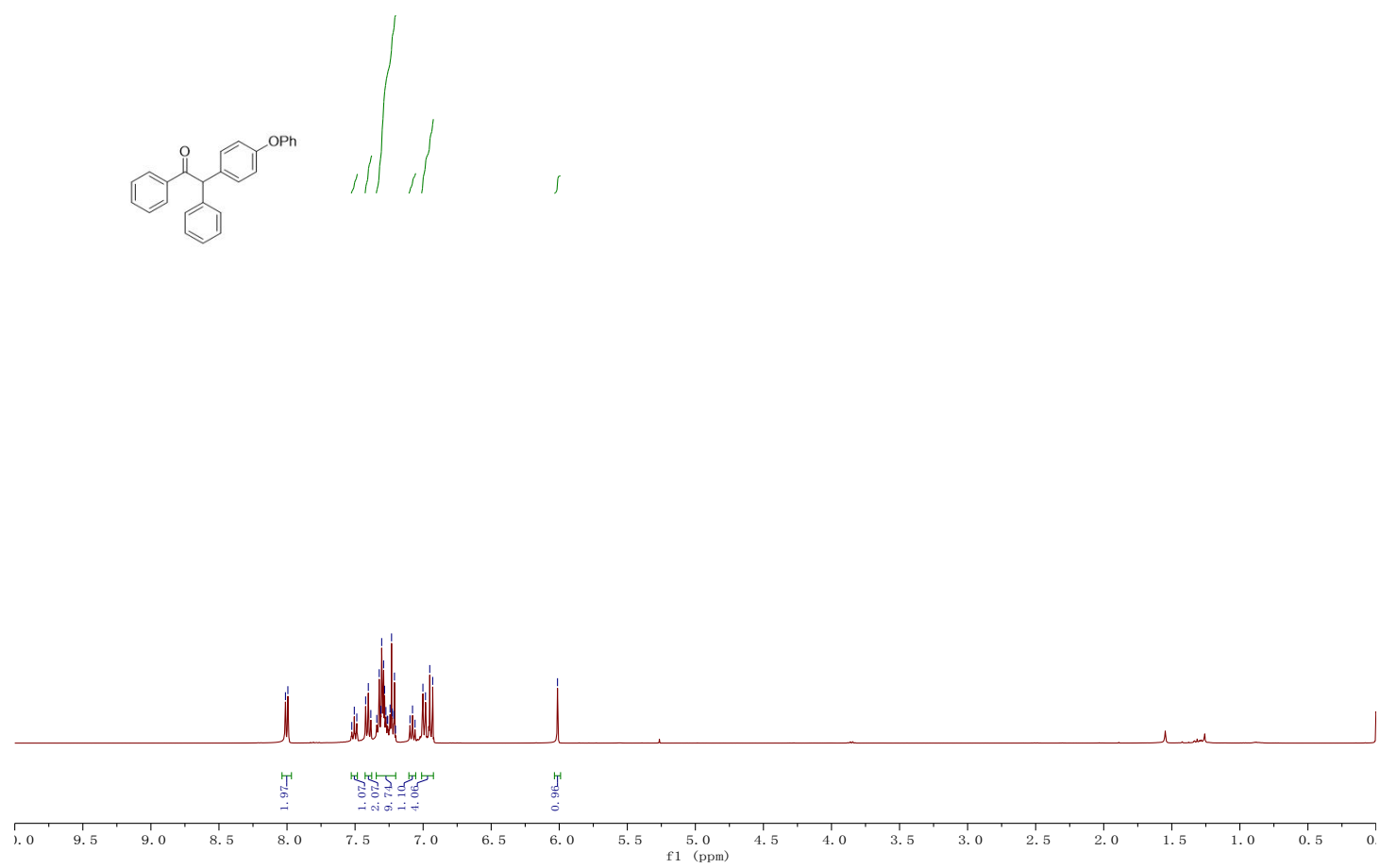

${ }^{13} \mathbf{C}$ NMR spectrum of $\mathbf{1 0}$ in $\mathrm{CDCl}_{3}(100 \mathrm{MHz})$

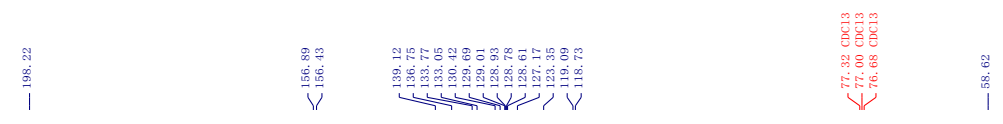
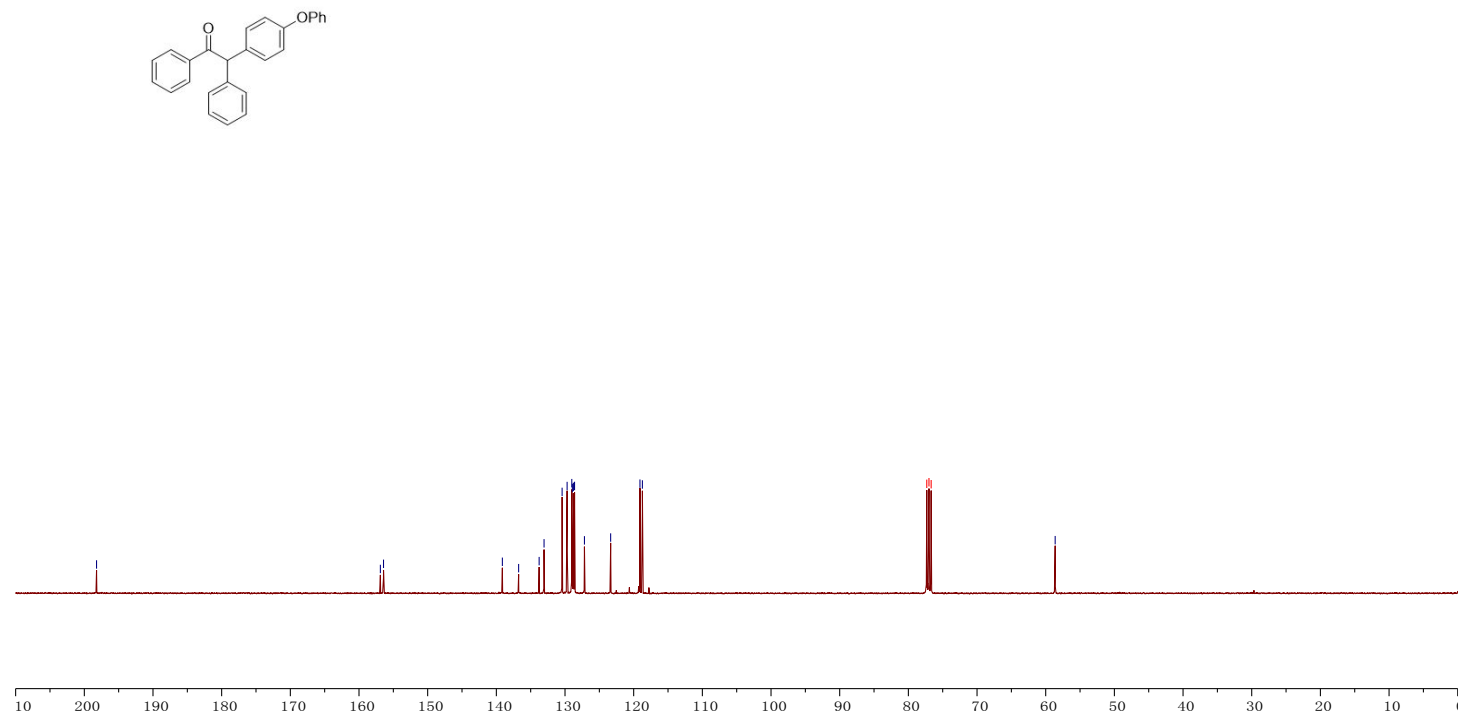

$\begin{array}{rr}110 & 100 \\ \mathrm{f} 1 & (\mathrm{ppm})\end{array}$ 
${ }^{1} \mathbf{H}$ NMR spectrum of 14 in $\mathrm{CDCl}_{3}(400 \mathrm{MHz})$
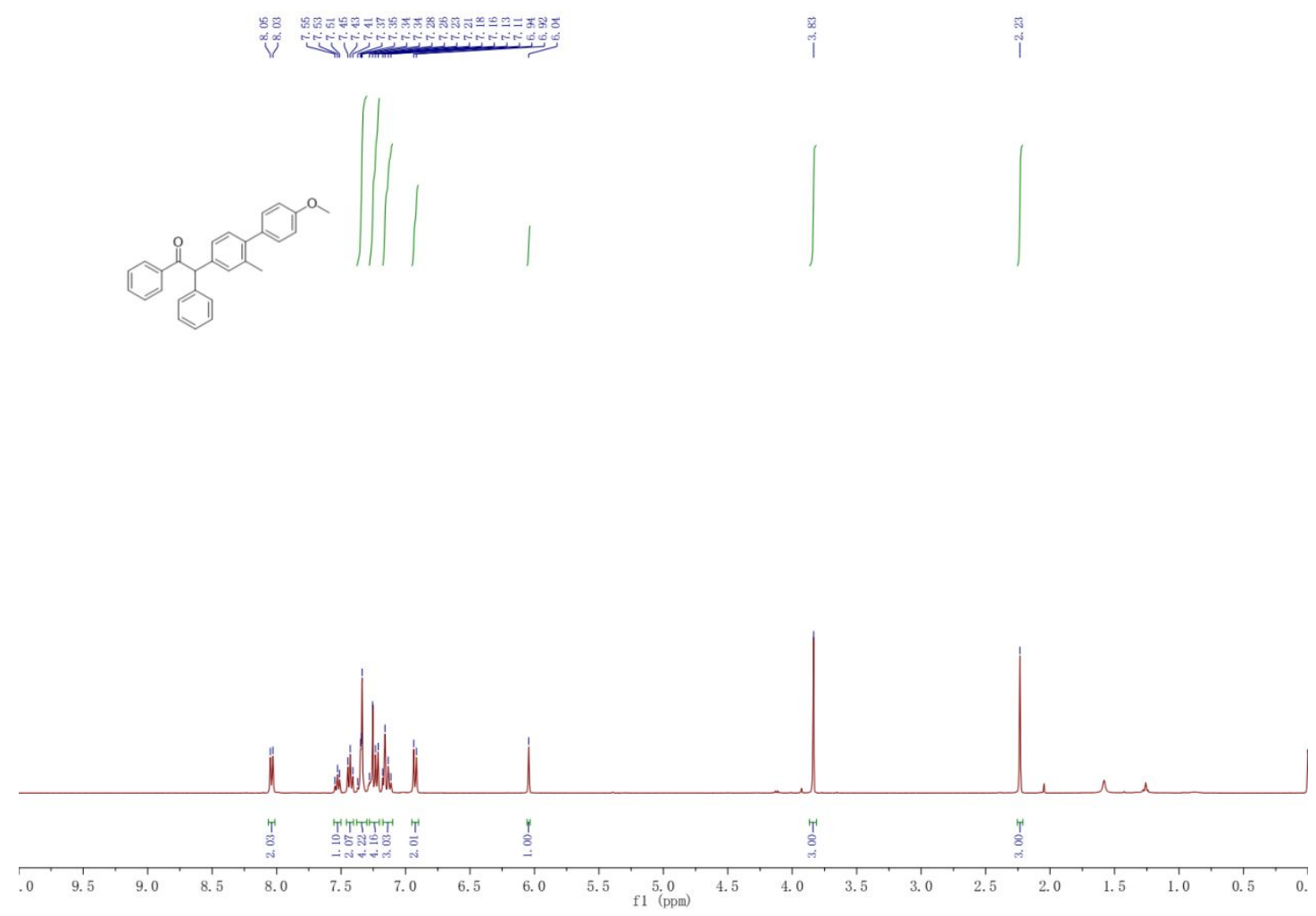

${ }^{13} \mathrm{C}$ NMR spectrum of $\mathbf{1 4}$ in $\mathrm{CDCl}_{3}(100 \mathrm{MHz})$

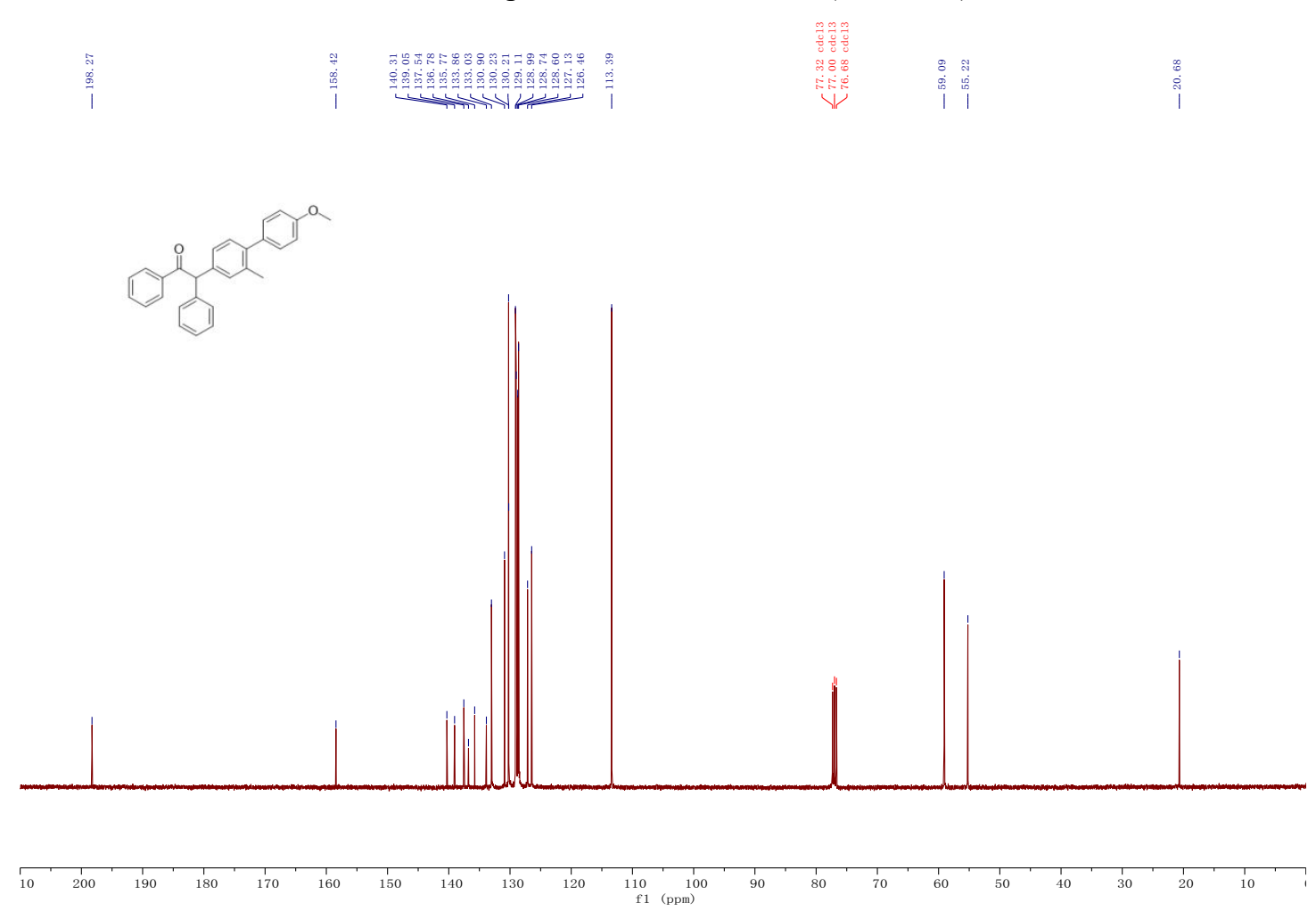

